\title{
جودة البيئة المدرسية وعلاقتها بالمواطنة التنظيمية \\ لدى معلمي مدارس محافظة أضم
}

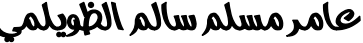

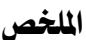

هدفت الدراسة إلى التعرف على جودة البيئة المدرسية وعلاقتها بالمواطنة التنظيهبة لدى معلمي

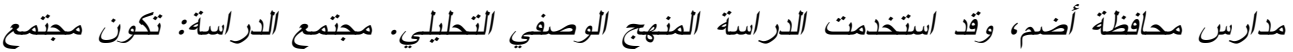

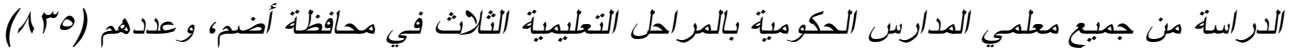

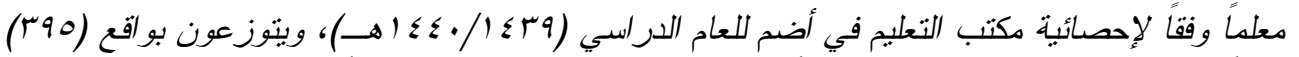

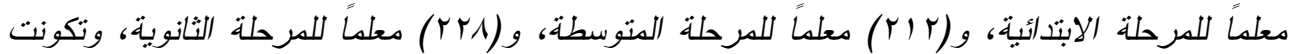

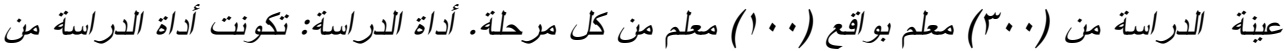
محورين: محور جودة البيئة المدرسية، وتكون من (س (T) فقرة موزعة على ستة مجالات، ودحور

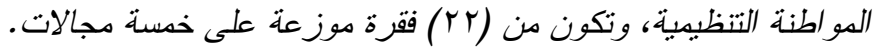

أظهرت نتائج الدراسة أن توفر مؤشرات جودة البيئة المدرسية في مدارس تعليم البنبن في محافظة

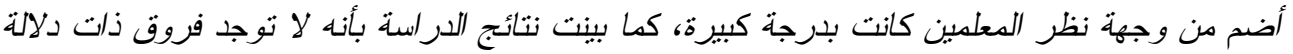

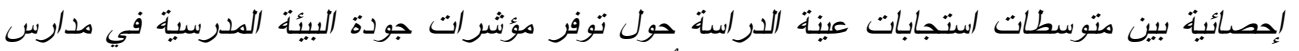
تعليم البنين في محافظة أضم في جيع المجالات تُعزى لاختلاف المؤهل العلمي، وإلى اختلاف المرحلة

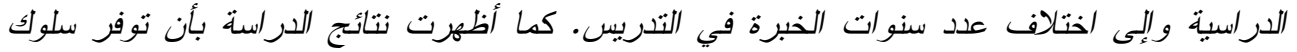
المو اطنة التنظيبة لدى المعلين في مدارس تعليم البنبن في محافظة أضم كان بدرجة كبيرة. وإلى عدم وجود فروق ذات دلالة إحصائية بين متوسطات استجابات عينة الدراسة تعزى لاختلاف المؤهل العلمي.

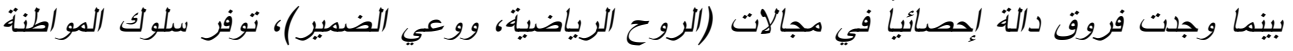
التنظيمية لدى المعلدين. ووجود فروق ذات دلالة إحصائية بين متوسطات استجابات عينة الدراسة تعزى لرفي

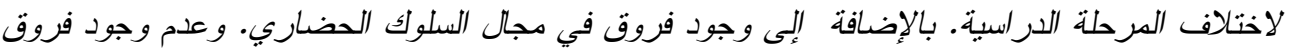

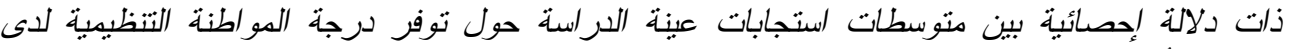

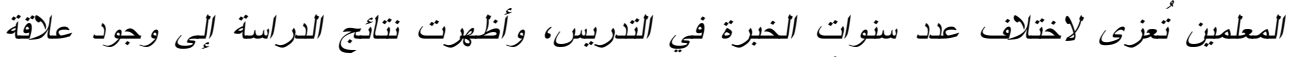
ارتباطبة طردية موجبة ودالة إحصائيًا عند مستوى الدلالة (0. . .) بين درجة توفر مؤشرات جودة البيئة المدرسية وتوفر سلوك المواطنة التنظيمبة لدى المعلمبن في مدارس تعليم البنبن في محافظة أضم، سواء في الدرجة الكلية لكل منهما وفي ضوء نتائج الدراسة فقد توصل الباحث إلى العديد من التوصبات ومن أهمها: تعبين أخصائي تدريب في كل مدرسة، نكون مهته تحبي الاحتياجات التدريبية للعاملين في المدرسة بطريقة علمية وصحيحة وفي ضوء احتياجاتهم الفعلية، وتوفير الأدوات والقوائم العلمبة اللازمة لتحديد الاحتباجات 


\begin{abstract}
The study aimed to identify the quality of the school environment and its relation to the organizational citizenship of the teachers of the schools of the province of Adhm. The study used the descriptive analytical method. The study population: The study population consists of all the teachers of the public schools in the three educational stages in the governorate of Adhm. The number of teachers is 835 according to the statistics of the Education Office in the year 1439/1440 AH. They are divided into 395 elementary teachers, 212 teachers, (228) teachers for the secondary stage. The study sample consisted of (300) teachers with (100) teachers from each stage. The Study Tool: The study tool was composed of two axes: the quality of the school environment, consisting of (33) paragraphs divided into six factors, and the axis of organizational citizenship, consisting of (22) divided into five factors.
\end{abstract}

The results of the study showed that the availability of quality indicators of the school environment in the schools of students education in the governorate of Assam from the point of view of the teachers was very much. The results of the study showed that there were no statistically significant differences between the responses of the sample of the study on the availability of quality indicators of the school environment in students education schools In the province of Assam in all areas due to the difference of scientific qualification, and to the difference in the school stage and to the difference in the number of years of teaching experience. The results of the study also showed that the availability of organizational citizenship behavior among teachers in boys' education schools in the governorate of Adham was very high. And the absence of statistically significant differences between the average responses of the sample of the study due to the difference in the scientific qualification. While there were statistically significant differences in the domains of (mathematical spirit and conscience consciousness), the behavior of organizational citizenship was provided by teachers. There were statistically significant differences between the mean responses of the study sample due to the difference in the school stage. In addition to differences in the field of civilizational behavior. The results of the study showed that there was a positive correlation between the mean of the quality of the school environment, The behavior of organizational citizenship is provided to teachers in students education schools in the governorate of Adhm, both in their total grade.

In the light of the results of the study, the researcher reached several recommendations, the most important of which are: The appointment of a training specialist in each school, whose task is to determine the training needs of the employees in the school in a scientific and correct manner and in light of their actual needs.

Keywords:Quality of School Environment,Organizational Citizenship, Adhm Governorate.

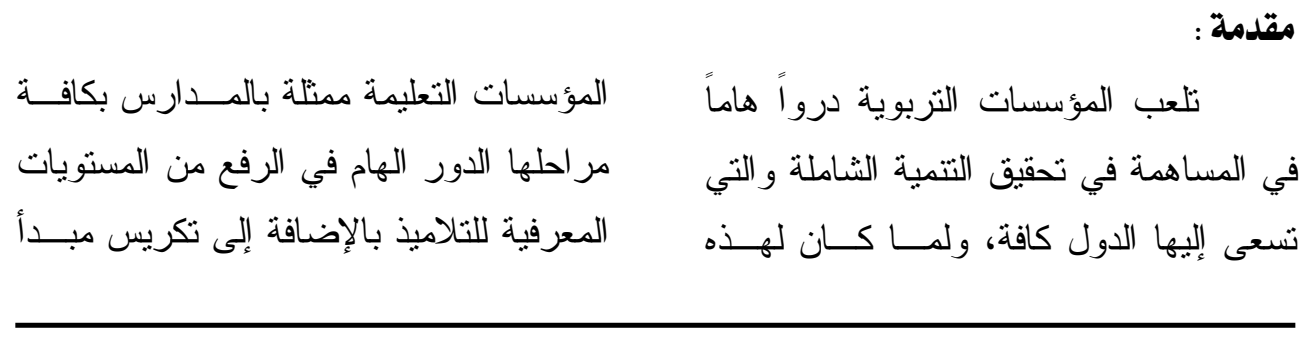




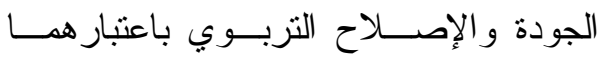

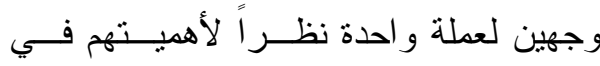
المؤسسات التعليمية (أحمد، 0 ( • Y، 9 9).

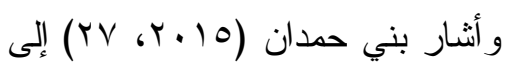
ضــرورة تطبيــق إدارة الجــودة الــشاملة بالمدارس كافة نتيجة انخفاض في مسستوى لدرد جودة التعليم وسوء المخرجات، وتــدني أداء

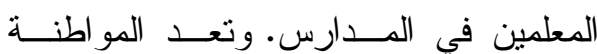
التتظيمية سلوكيات إيجابية بمارســـها الفـرد

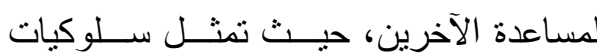

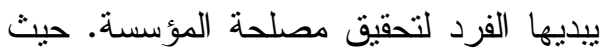

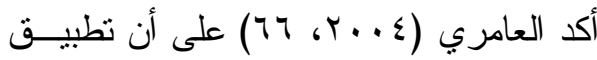

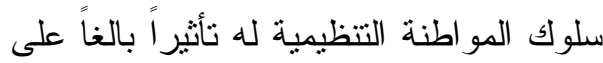

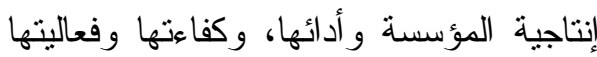
لأنها تعزز مبدأ العدالة.

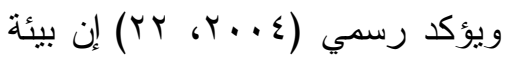

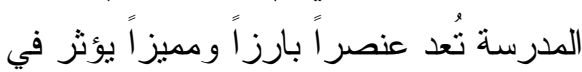

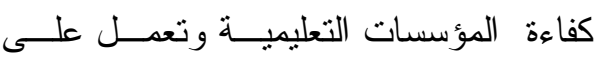

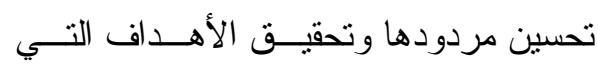

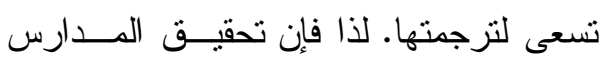

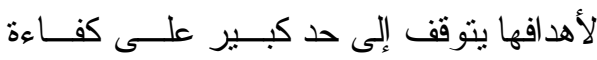

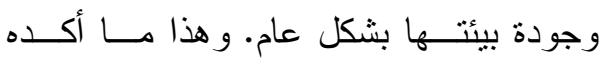

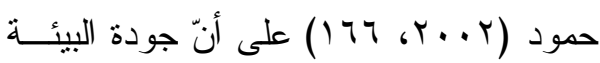

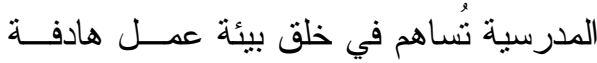
وتعزز من مستويات الأداء و التماسك بــين بــين

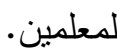

المو اطنة لــدى الطــلاب لتعزيــز الـــولاء والانتماء، وبواسطة هذه المــدارس تـسعى

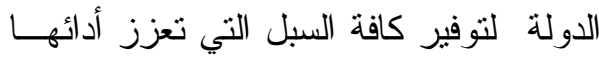

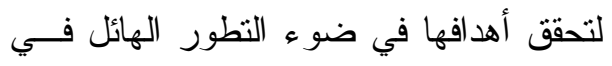

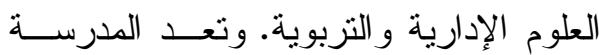

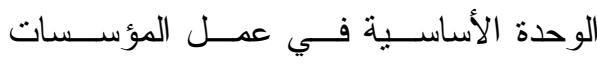
التربوية التي يعهد إليها بــأن تتـوب عــن المجتمع في تحقيق أهداف التربية. لذلك فإن

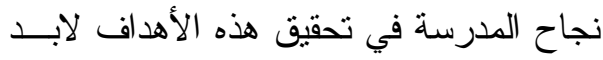

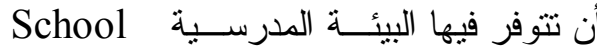
Environment .$(r 4$ ومع تطور البيئة التعليمية فقد أصبح

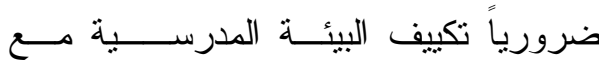
التوجهات الإدارية الحديثة، وتطوير العلاقـــة بين المعلم و الطالب و الانفتاح علــى البيئــة

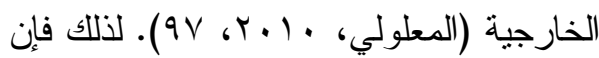
تجويد نظام تربوي ينهض بــستوى الفــرد و المجتمع في ظل وجود بيئة تعليمية مميـزه وجاذبة تتمتع بمعايير الجودة الثاملة Total Quality

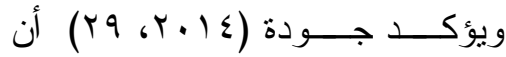
تحسين بنية النظام التعليمي بكافــة مكوناتــهـ

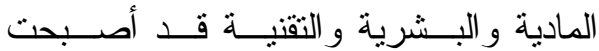

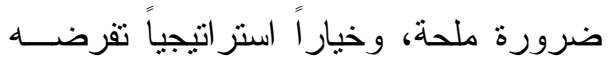
طبيعة الحر الك التعليمي و التزبوي في العصر

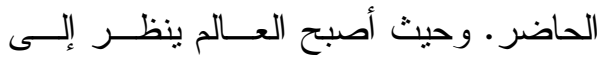


مرنة بحيث تتسجم مع الظروف المحلية لكل

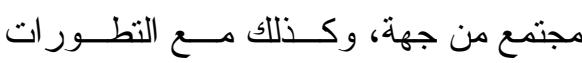
الجارية على الصعيد التربوي من جهة ثانية. و أكدت توصيات المنظمـــة العربيـــة

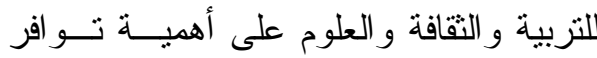
مختلف منطلبات العملية التزبوية و التعليميــة في المؤسسات التعليمية كافة، وأن تكون هذه

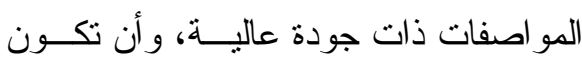

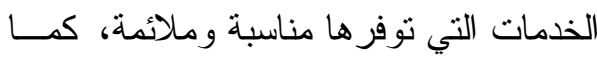
يتطلب أن نز اعي البيئة التعليميــة للطــلاب

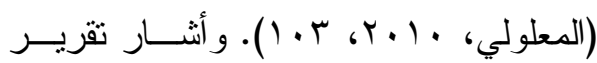
شبكة دعم المعلم و المركز البريطاني للبيئــة

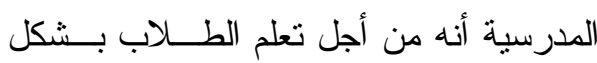
أفضل وفعال، ومن أجل أن تـــبح عمليـــة

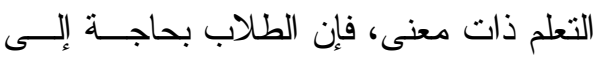
الثعور بالأمان و الأمن و الر احة داخل بيئــة المدرسة (Asiyai, 2014, 719).

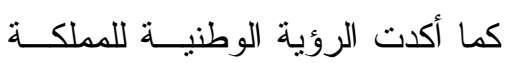

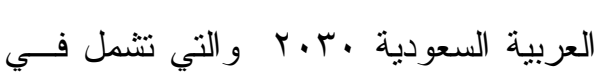
الهدف الاستر اتيجي الثالث على تحسين البيئة

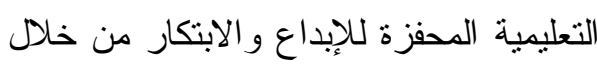

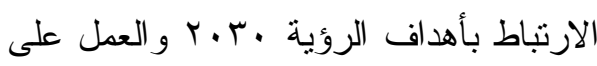
ترسيخ القيم الإيجابية وبناء شخصية مستقلة لأبناء الوطن (برنامج التحوّل الوطني- رؤية .

ولضمان تحقيــق الرؤيـــة الوطنيـــة

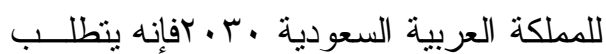

و انطلاقاً من أهمية الدور الذي تقــوم به المدارس فلا بد من تجويد بيئتها فإن ذلك

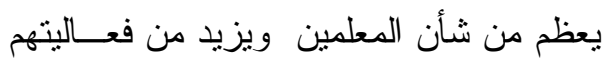

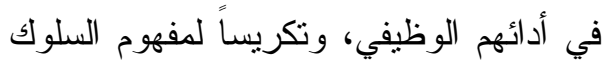

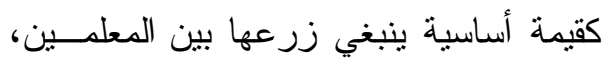

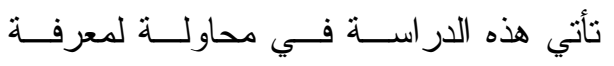
واستقصاء العلاقة بين جودة البيئة المدرسية وسلوك المو اطنة التظظيمية لدى المعلمين.

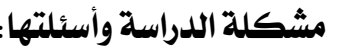

تعد البيئة المدرسية الحلقة التعليميــة

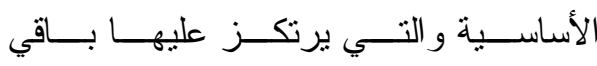
المستويات، وهذا يتطلب من المدرسة توفير

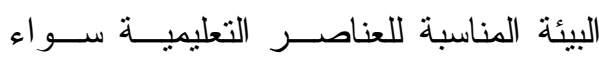
الإدارة المدرسية أو المعلمـين أو الطــلاب باعتبار هم الحلقة المكونة لوجود المدرســة.

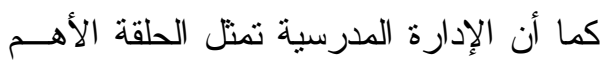
في توفير البيئة المدرسية المناسبة والملائمة

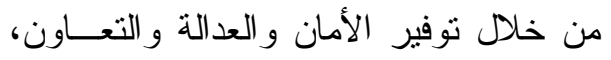
كما تعد الجهة الداعمة لزيادة العلاقات بــين

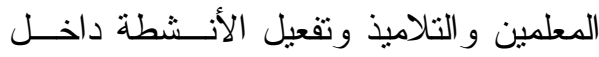

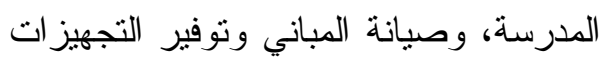

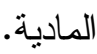

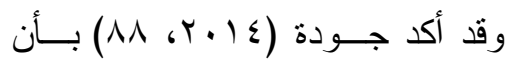
هنالك العديد من العوامل داخل بينة المــدرس

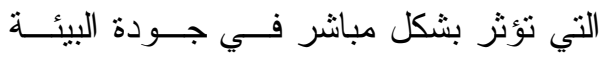

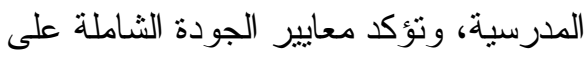

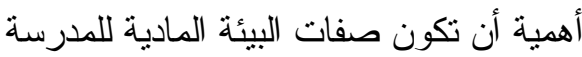


إلى ضعف مستوى جودة البيئة المدرســية.

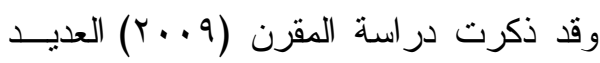
من العوامل التي تؤثز على تحقيق مؤشرات

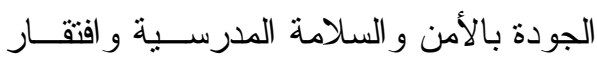
البناء المدرســي لقو اعــد معــايير الامــن

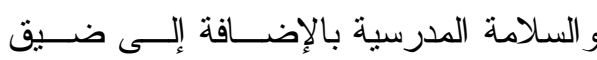

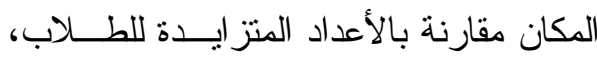
مما يجعل هذه العو امل تشنكّ عو امل تحد من دافعية و أداء المعلمين وتدني سلوك المواطنة التتظيمية لدى المعلمين. وهو ما أكدت عليه العديد مــن الدراســات (مثــل، العــامري،

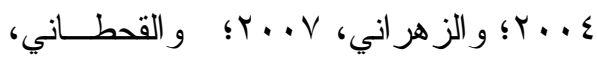

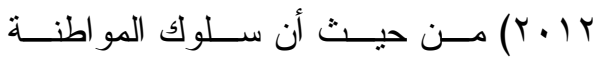
التتظيمية تتأثز ببيئة المؤسسة. فقد اثـــارت نتائج العديد من الدراسات و لاسيما در اســـة

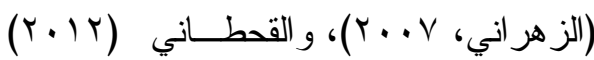

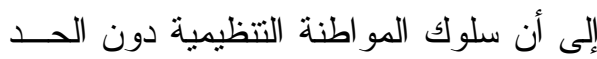
المأمول المطلوب توفره في البيئة المدرسية. كما بينت الفرجاني (r lV) إن غياب سلوك المو اطنة التتظيمية يحمل في طياتـــه الكثيـر من المشاكل و السلبيات، حيث يــؤدي إلـى ضعف مستويات الأداء ويؤدي إلى ضعف

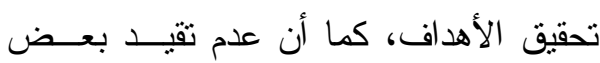
المعلمين بالحضور و الانصر اف في الوقــت

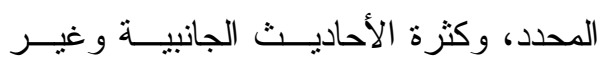
النافعة التي تؤدي إلى إضناعة الوقت ويهدر المزيد من الجهود في تحقيق الأهداف.
تجويد البيئة المدرسية نحو الأفـضل. إلاّ أن

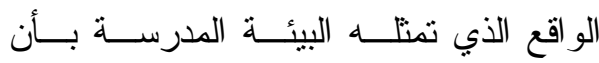

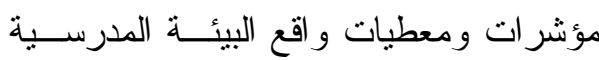

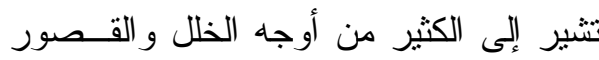

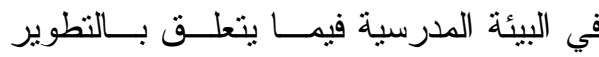

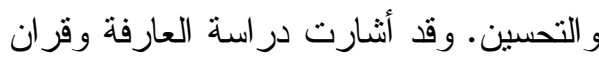

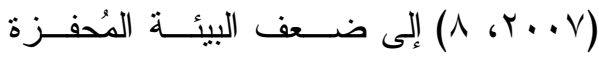

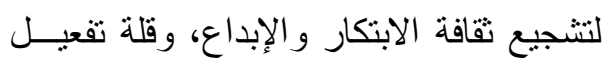

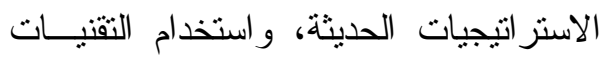
في التعليم ومشكلات المباني المستأجرة وقلة

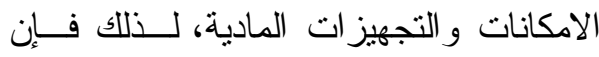
أوضـاع التعليم لا تــز ال كمـــاً وكيفيــاً دون مستوى الطموحات وتحتاج إلى المزيد مسن الجهود لتوفير البيئة المناسبة وهذا كله يؤدي إلى ضعف إنتاجية المعلمين داخـلـل البيئــة

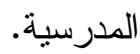

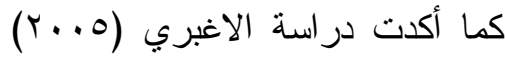

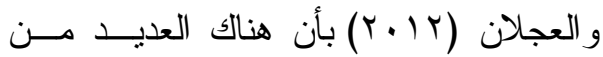
المعوقات في تطبيق إدارة الجــودة الــشـاملة تتعلق بمتطلبات البيئة المدرســية ولاســيما

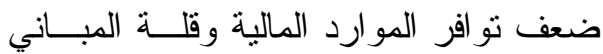
الحكومية التي توفر البيئة التعليمية المناسبة،

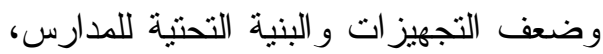
بالإضافة إلى سوء تو افر المناخ التنظيهـي،

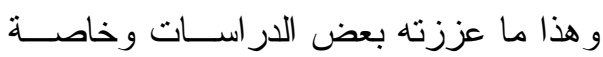

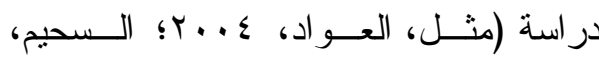

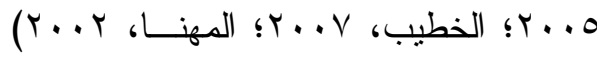


المواطنة التظظيمية لدى المعلمـين فــي

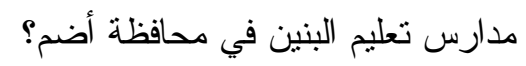

أهداف الدراسة:

تهدف الدراسة الحالية إلى التعــرف

على مؤشرات جودة البيئة المدرســية فــي لئي مدارس تعليم البنين في محافظة أضـــم مــن

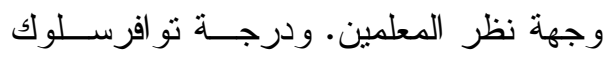

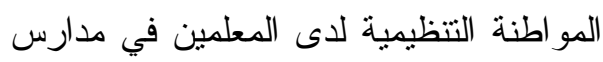

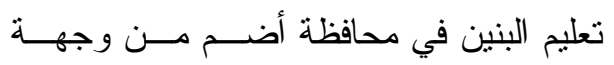

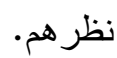

\section{ثانياً: الدراسات السابقة:}

أولاً: الدراسـات المتعلقـــة بجــودة البيأســة المدرسبة:

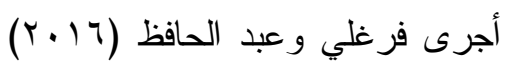

دراسة هدفت إلى التعرف على العلاقة بــين

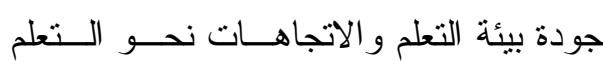
وكذلك اكتثاف الطلاب الموهوبين بالمرحلة

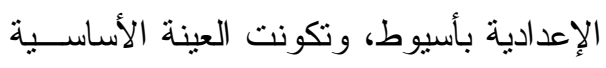

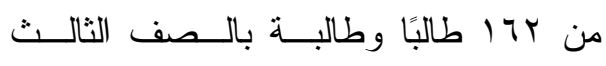

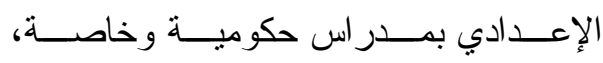
و استخدمت الدر اسة استبيان دعم بيئات التعلم الإيجابي، ومقياس الاتجاهات نحــو الــتـعلم ومقياس الخصائص الــسلوكية للموهـــــين. وتوصلت الدراسة إلى العديد من النتائج كان

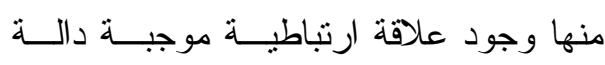

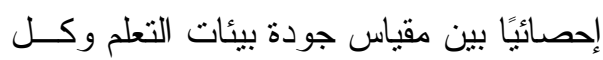
من الاتجاهات نحو التعلم و اكتشاف الطلاب
ومن خلال عمل الباحث في مدارس

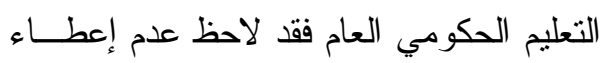

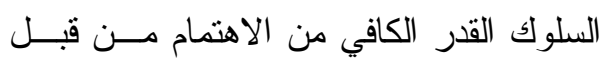
المعلمين وتقيدهم بالدور الإلز امي (الرسمي)

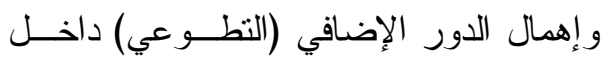
المدرسة على الرغم من أهميته، بسبب قلــــة

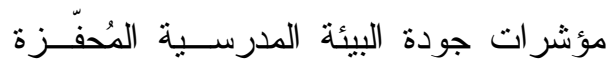

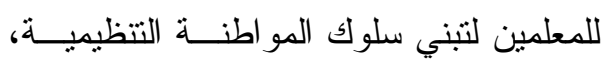
مما دفع بالباحث إلى إجر اء هـــذه الدر اســــة للكثف عن العلاقة بين مؤشر ات تحقق جودة

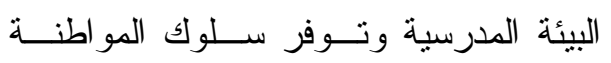

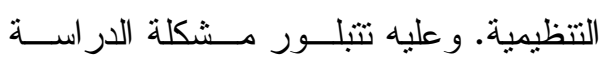

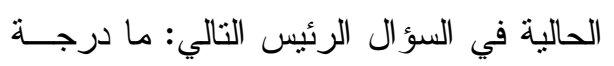
تحقق مؤشرات جودة البيئة المدرسـية فــي لـئي مدارس محافظة أضم وعلاقتهــــا بالمو اطنـــة التتظيمية لدى المعلمين؟ ويتفرع من السؤال الرئيس الأسئلة الفرعية التالية: ا ـ ما درجة نو افر مؤشرات جــودة البيئــة

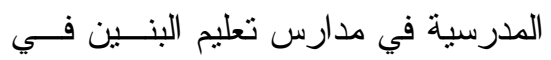
محافظة أضم من وجهة نظر المعلمين؟ r. ما درجة تو افر سلوك المو اطنة التتظيمية لاى المعلمين في مدارس تعليم البنين في

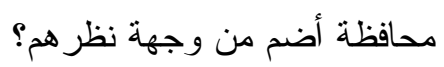
r. هل توجد علاقة ارتباطيــهـ ذات دلالــــة إحصائية بين درجة تحقـق مؤشــرات

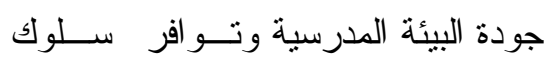


للمعلمين البارزين في ممارســتهم التربويــة

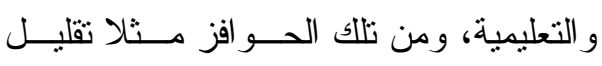

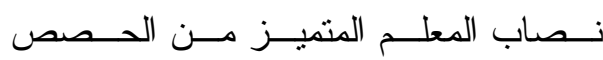

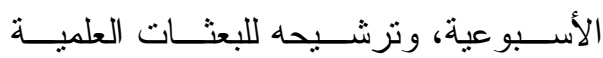
الخارجية، وتفريغه لمو اصلة در استه العليــا، ولئه

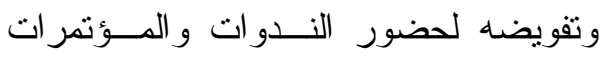

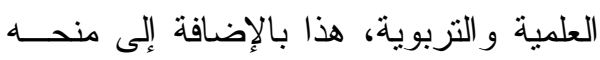
العلاوات التشجيعية التي تتتاسب مع ما بذل بلزبل

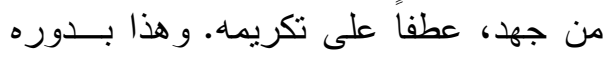
يحفز باقي المعلمين على الاقتداء بهاه و الــسير على نهجه، و الموازنة بين عــدد المعلمــين ومساحة المدرسة وعدد الفصول الكائنة بهـــا وبين عدد الطلاب حتى لا يحــدث ازدحسـام

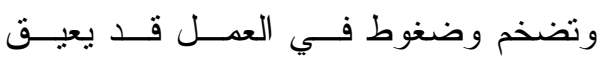
المعلمين عن أداء دورهم التربوي و التعليمي بكفاءة وفاعلية. وقد أجرى الحناكي (10 ـ ب) دراسة هدفت إلى التعرف على المقومات البــشرية

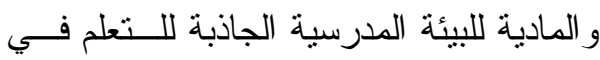

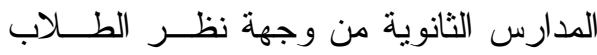

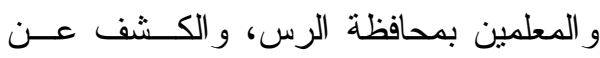

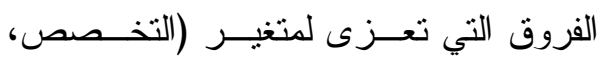
الصف الار اســي) حــول مقومــات البيئــة المدرسية الجاذبة للتعلم. و استخدمت الدراسة المنهج الوصفي المسحي، و اعتمدت في جمع ولي

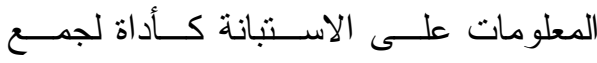
البيانات، و اختيرت العينة بطريقة عـشوائية
المو هوبين، كما وجدت فــروق ذات دلالــــة إحصائية على مقياس بيئات التعلم حسب نوع ونين المدرسة (حكومي- تجريبي لغات- خاصة) وذللك لصالح المــدارس التجريييــة لغـــات،

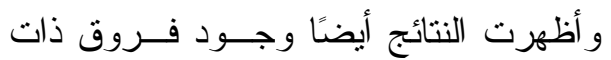
دلالة إحصائية على مقياس الاتجاهات نحسـو

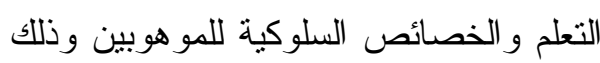
حسب نوع المدرسة وذللك لصالح كـلـل مــن ولـن

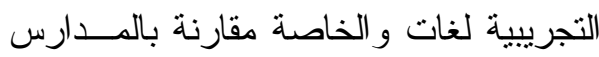

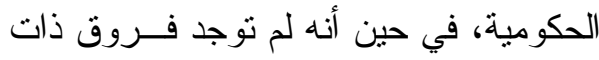

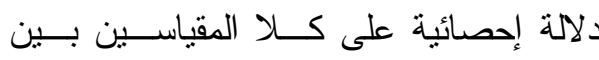
المدارس التجريبية و المدارس الخاصة.

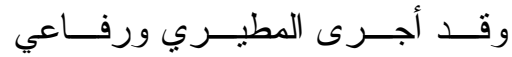

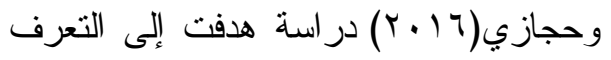
على دور البيئة المدرسية في رفع مـستوى الرضـا الوظيفي لمعلمي المــــارس الثانويـــة بدولة الكويت، تضمنت تحديد الأطر النظرية

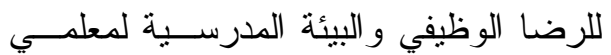
المدارس الثانوية بدولــة الكويــت، اتبعـــت

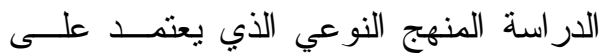

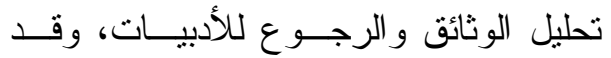
اسفرت النتائج عن بيان دور البيئة المدرسية

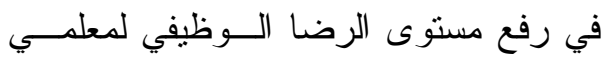
المداس الثانوية بدولة الكويت من خلال بناء الثقة في قدر ات المعلم ومهارته و التي تؤهله لأداء دوره في العملية التزبوية، و الاهتهــام

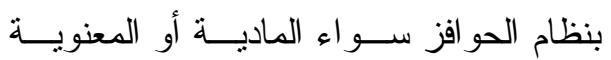


و التصميم ومن حيث نوفير الثروط الصحية

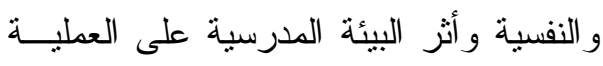

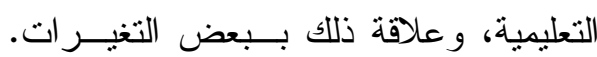

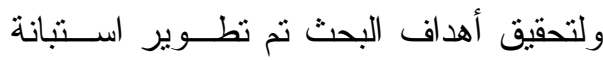

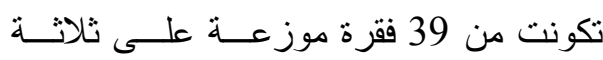

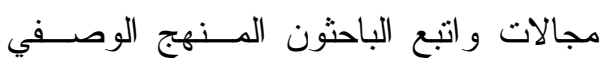

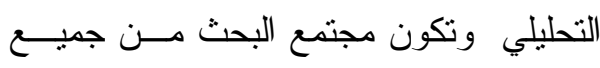

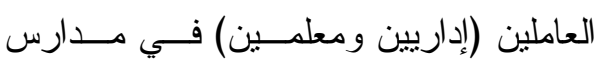

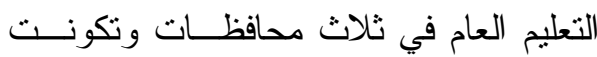
العينة من (ع VY) فرداً تم اختيار هم بالطريقة العشو ائية، وبينت النتائج أن و اقـــع تــصميم وموقع المدارس مناسب بدرجة منوسطة كما

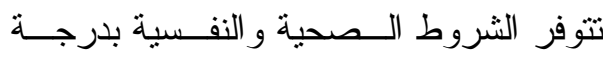
متوسطة أيضاً وأن البيئة المدرســية تــؤثر إيجاباً على العملية التعليمية بدرجة متوسطة كما بينت النتائج عدم وجود فروق ذات دلالة

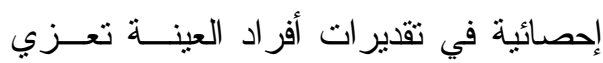

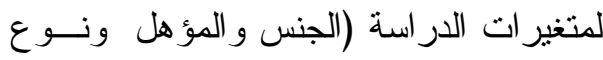

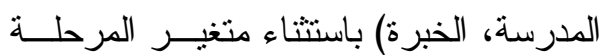

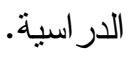
أهـــــا در اســــة ســـليمان وحـــسين ف (Suleman, Hussain, 2014) الباكستان فقد هدفت الى دراسة آثار البيأـــة

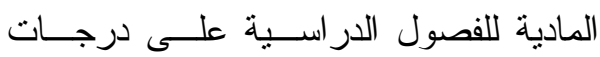

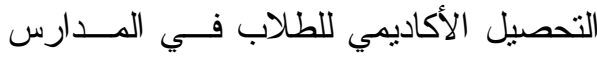

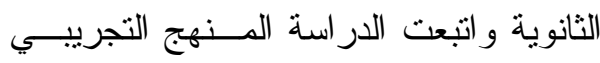
حيث تم اختبار مجمو عتين ضابطة تجريييــة
عنقودية، و التي تكونت من طلاب المرحلـــة الثانوية بنين في المدارس النهارية الحكومية، ونكان

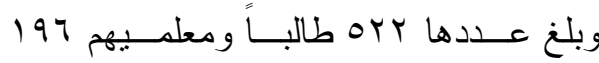
و أبرز النتائج أن تتو اصل الإدارة المدرسـية ومعلية

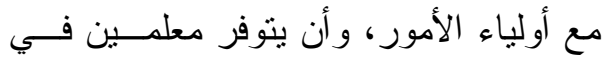

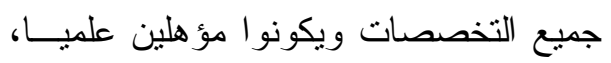
وأن تمنح الإدارة المدرسية حوافز تـشئيعية للطلاب المتميزين در اسيا، وأن يتوفر مرشد

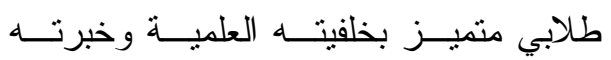

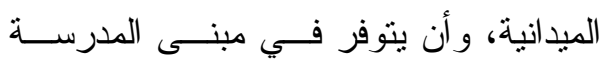

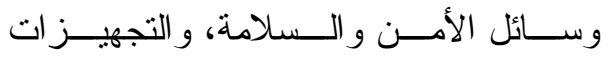

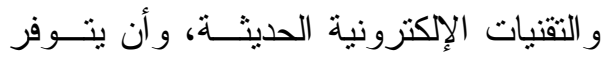

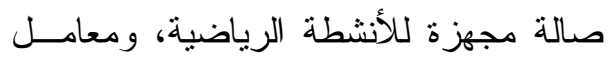

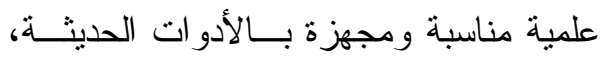
و أظهرت النتائج عدم وجود فروق للمقومات

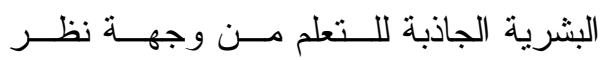
المعلمين باختلاف متغير التخصص، ووجود فروق ذات دلالة إحصائية بين أفراد عينــة الدراسة من الطـــلاب للمقومــات البــشرية

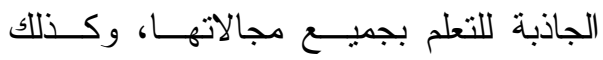

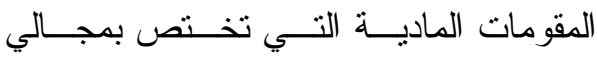
(المبنى المدرسـي، المحتــوى التعليمـي)، لصالح أفراد عينة الدراسة من طلاب العلوم الثرعية وتحفيظ القرآن الكريم. وفــي در اســـة العجمــي و الــذروة

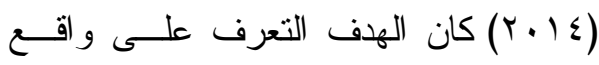
البيئة المدرسية في الكويت من حيث الموقع 
المدرسية ورضا المعلمين الوظيفي باستخدام

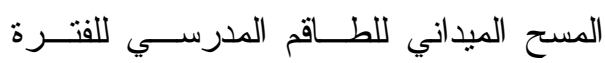
(Y.. - Y . . . V) المنهج الوصفي التحليلي، وسئل افراد العينة عن شعور هم العام نحو المهنة، حيث أجري تحليل معامل الانحدار لقياس الرضا الوظيفي

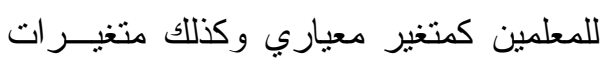

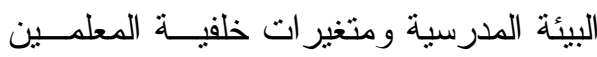

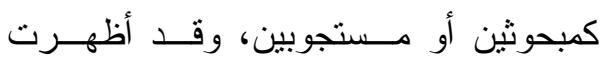

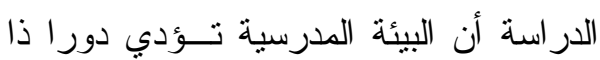

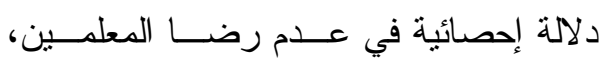
وبشكل خاص الاستقلال الذاتي للمعلمين و أن

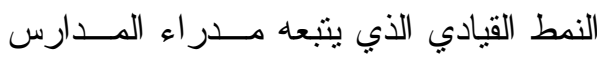

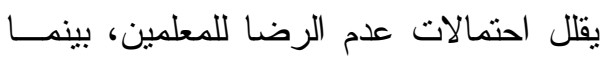

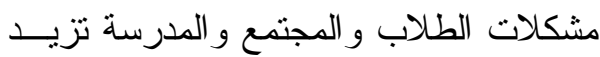

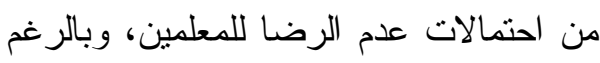
من الأخذ في الحسبان تز ايد تميـز المعلــم ووضع المدرسة المنوسط، وموقع المدرســـة الريفية فأنها بقيت ذات دلالة إحصائية.

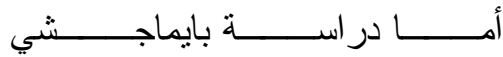
فقد هــدفت الــى (Byamugisha, 2011) التعرف علــى مقومــات البيئــة المدرســية الجاذبة و المحفزة للــتعلم، وتكونـــت عينــة

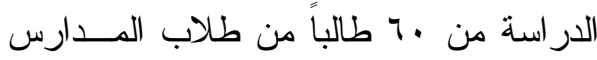
الابتدائية، و أستخدم الباحث المنهج الوصفي، من طن

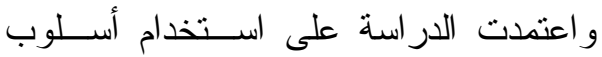
مر اقبة نوعية التعليم داخل مدارس أوغنــدا
وتكونت كل مجموعة من 20 طالبــاً مــن طلاب الصف التاسع وتم إجر اء اختبار قبلي للمجمو عتنين ثم درست المجموعة التجريبيـــة في فصول مناسبة مادياً ودرست الــضابطة في فصول بسيطة (غيــر مجهـزة وغيــر منظمة) وأظهر الاختبار البعـدي أفـضلية للهجموعة التجريبية، ويعزي ذلك لأثر البيئة المادية للصفوف. وقد اجرى القروني (ع ا •r) دراسة هدفت إلى الكثف عن دور الإدارة المدرسية

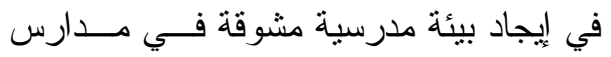
فلسطين من وجهة نظر المعلمين و المعلمات فيها - محافظة سلفيت أنموذجاً، تكونت عينة وهنة

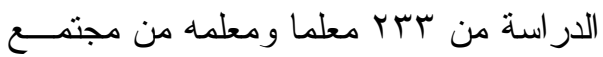

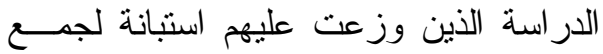
البيانات اللازمة، ولتحقيق أهداف الدراســـة و التحقق من صــحة فرضـــاتها، اســتخدم

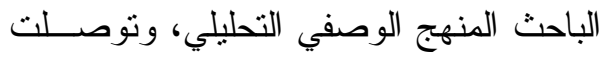
الدراسة إلى نتائج من أهمها: يوجد دور كبير للإدارة المدرسية في خلــق بيئـة مدرســية مشوقة في مدارس محافظة سلفيت من وجهة نظر المعلمين و المعلمات فيها، كما يوجد لها

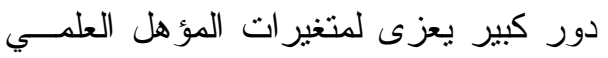

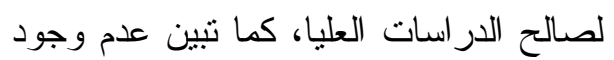
فروق تعزى الى المرحلة الدر اسية. وفي در اسة كـار ا (Cara, 2012) التي هدفت إلى بحث العلاقـــة بــين البيئــة 
و استخدمت الاسنبانة في جمع البيانات، وقــــ بينت نتائج الدر اسة أن درجة ممارسة مديري

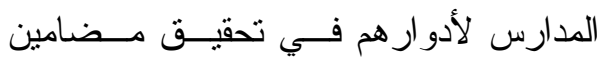

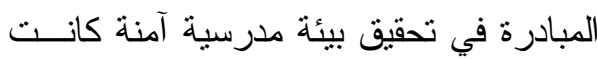
بدرجة كبيرة. كما بينت نتائج الدر اسة وجود لئه

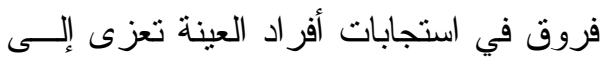
متغير النوع الاجتماعي لصالح الإناث، وعدم لهن

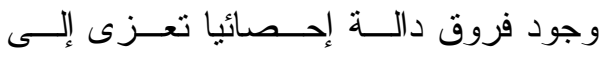
متغير ات الخبرة و المؤهل ومستوى المدرسة في جميع المجالات و الأداة ككل. وفي دراسة مـاتر (Matar, 2010) والتي هدفت الى التعرّت على أنثـر البيئـــة المدرسية الجاذبة وتصميمها على تحـصيل الطلبة الأكاديمي ودافعيتهم للتعلم"، تكونـــت

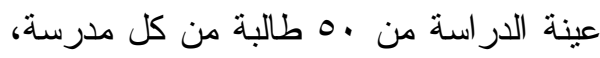
و استخدم الباحث المنهج الوصفي، و اعتمدت الدراسة على اســتخدام أســلوبي الاســتبانة

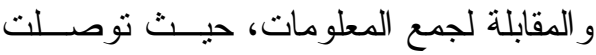

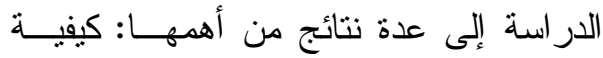

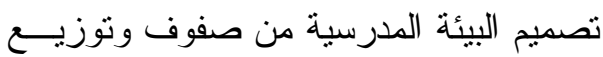
الطالبات نؤثز بشكل أساسي على تحصبلهن منئ خصوصاً في مادة الرياضـــيات، و أن البيئــة الصفية المناسبة تؤثز على دافعية الطالبـات الترات وحبهن للتعلم، وأن للبيئـة المدرســية دور إيجابي في زيادة نسبة الإبداع لديهن، كما أن

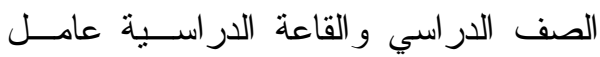
مشجع ومحفز للتعلم و التفكير و الإبداع.
الحكومية، وتوصلت الدر اسة إلى عدة نتــائج من أهمها: أن الطالب الذي يتتــاول الغــــاء

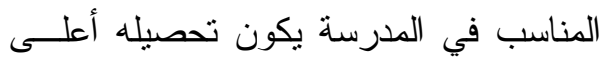
من زملائه، كما أن موقع المدرسة يجب أن

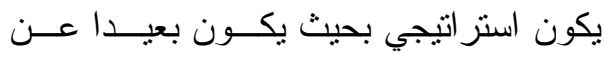

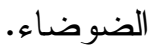

كما أن در اسة فاندفر ( Vandiver,

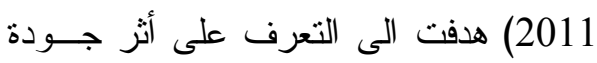
مر افق المدرسة داخل البيئة المدرسية علـى تعلم الطلاب، وتكونت عينة الدراسة من بـ مدير ومديرة من مديري المدارس الثانويــة في تكساس في الولايات المتحدة الأمريكيــة،

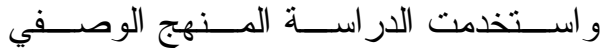
التحليلي، و اعتمدت على أســلوب المقابلـــة. حيث توصلت الدر اسة إلى عدة نتــائج مــن ولن

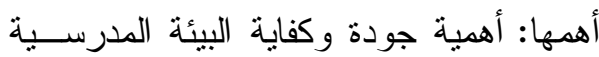
و التعليمية من المر افق التعليمية، بحيث تكون

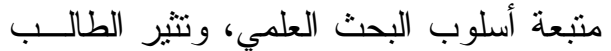

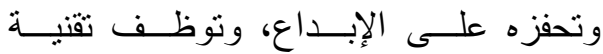
المعلومات في العملية التعليمية.

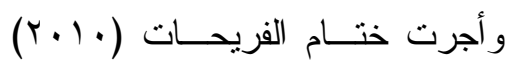
در اســة هــــت إلــى تعــرف دور الإدارة المدرسية في تحقيق مضامين مبادرة جلالـــة الملكة ر انيا العبد اله "معا نحو بيئة مدرسـية مئة

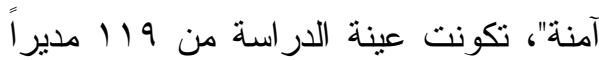

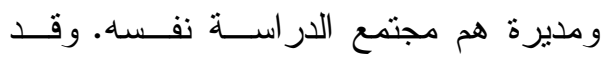

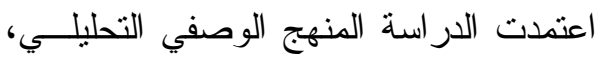


وتم إعداد اختبار للمــستوى الــذي يوضـــح السلوكيات التي يجب على الطلاب اكتسابها، وتوصلت الدر اسة إلى أن التعلم فــي بيئــة

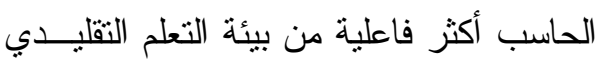

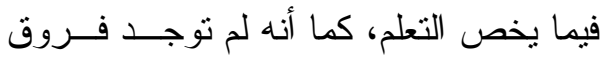
ذات دلالة إحصائية ما بين بيئـات الـتـعلم،

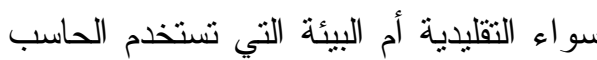
فيما يخص تذكر ما نم تعلمه.

Gough, ) كما أن در اســـة كـــوف

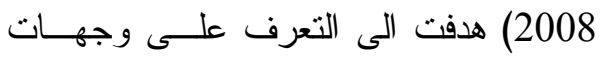
نظر أولياء الأمور في المناخ المدرسي فــي مدارس المدن الأمريكية، من ناحية مكونات

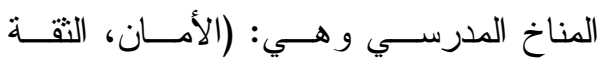

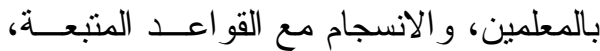
و التوقعات العالية للتحصيل و الإنجاز ، وبيئـــة

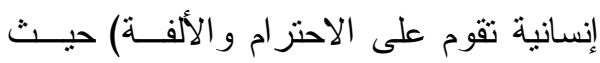

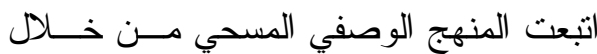
المشروع الذي تبناه مجلس هيئات التعليم في لبي المدن حول المسح الذي أجر اه لآر اء الآبــاء

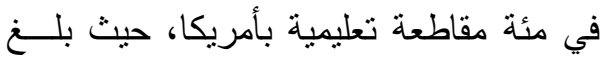

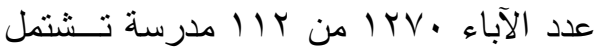
على جميع الصفوف الدراســية، و أظهــرت النتائج أن شعور الآباء كان جيدا حول البيئة التعليمية التي وفرتها المدارس لأبنائهم؛ حيث

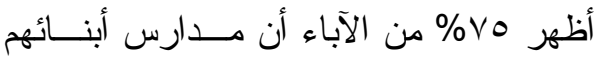

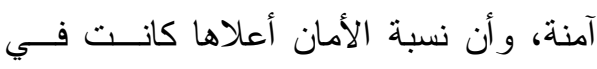

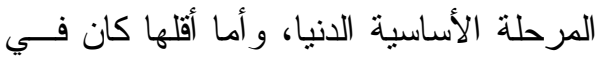

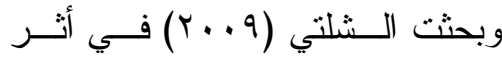

منظومة البيئة المدرسية فـي نتميــة القـيم

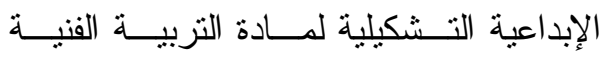
بالمرحلة الثانوية من وجهة نظر المعلمــات واستخدمت الباحثة المنهج الوصفي وتكونت العينة من 101 معلمة من معلمــات التربيــة

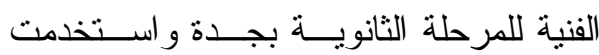

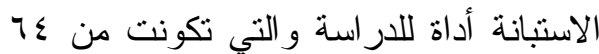

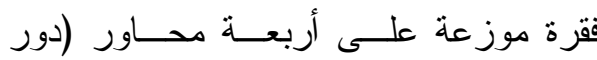

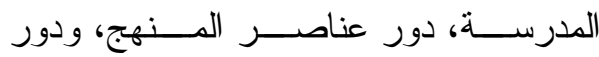

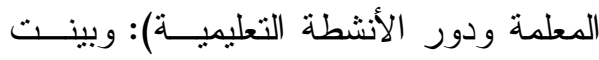

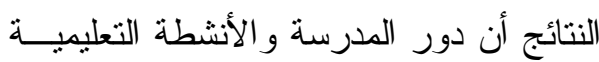
و عناصر المنهج في تتمية القـيم الإبداعيــة كانت منوسطة فيما كان دور المعلمة عاليــاً، وبينت النتائج وجود فروق تعـزي للخبـرة و التخصص و الدورات التدريبية و لا توجـــ فروق تعزي للمؤهل. أما در اسة كوسـي (Kose, 2009) فقد هدفت إلى تقويم فاعلية البيائــة التعليميــة

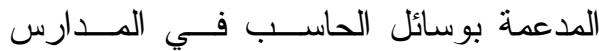
الابتدائية، ولقد تم تقييم البيئة التعليمية فيمــا يخص تعلم الطالب وتذكر ما تعلموه وتمــت المقارنة بين المجموعة التجريبية و المجموعة الضابطة بخصوص الثأثثر الذي يحدثه التعلم

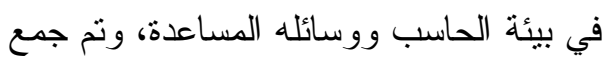
البيانات من خلال اختبار بعدي في الوحــدة وليد الأخيرة للمجموعة الضابطة خلال الدراسة، لئال 
صحية. وتكونت عينة الدراسة و التي تكونت

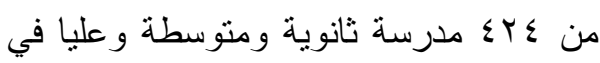

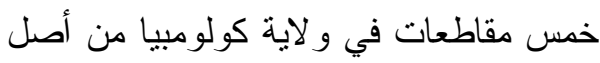

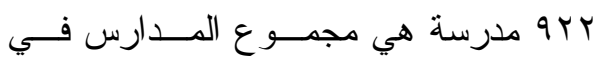

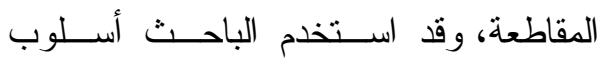
المقابلات لجمع البيانات وقد أظهرت نتــائج

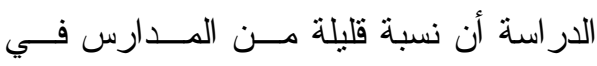

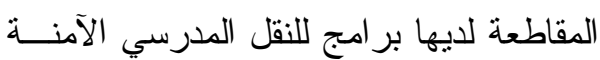

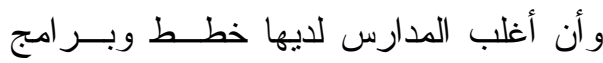

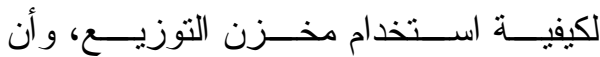
ع، إ\% من المقاطعات لديها سياسات فـي مجال المبنى المدرسي الأمن.

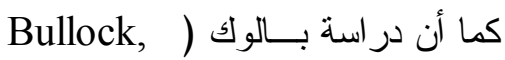
2007) هدفت الى معرفة العلاقة بين حالـــة المبنى المدرسي و التحصيل الأكاديمي لطلاب

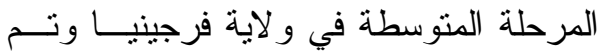
تصنيف المدارس حسب اســتجابات مـــر اء المدارس على استنيان قياس تحقيق المدرسة للمعايير المعتمدة ثم تم قياس العلاقــة بـين حالة المبنى ودرجات الطلبة (الصف الثامن) في اختبار الولايـــة فـــي اللغــــة الانجليزيـــة

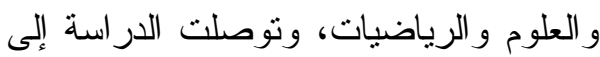
وجود علاقة ارتباطية موجبــة بـين حالـــة المبانى الهيكلية و الجمالية وتحصبل الطلبــة في الاختبار العام للو لاية.

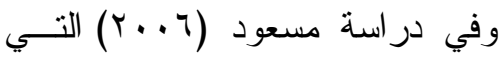
هدفت اللى التعرف علــى منطلبــات البيئــة
المرحلة الثانوية. وأن ع>\% منهم يثقون في

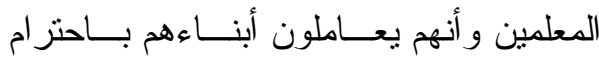

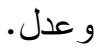

أما دراسة مجلس الأطفال الموهوبين

(Council Talented Children, 2008) بعنوان "سياسة جمعية الأطفال المو هوبين في

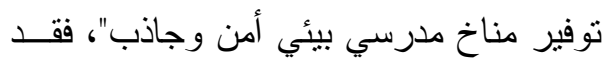

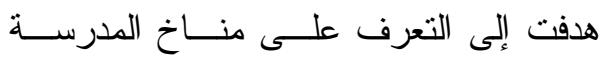

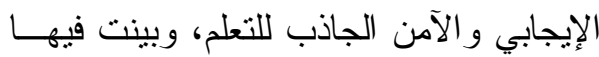

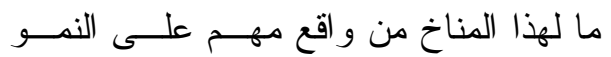
الفردي و التحصيل الأكاديمي لجميع الطلاب، مستدله بما انتهت إليه الدراسة التي تشير إلى الى

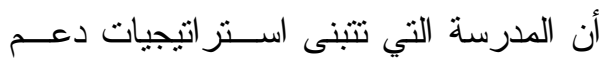
المناخ المدرسي الإيجابي هي أكثر فاعلية في تلي

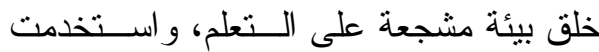
الدراسة المنهج الوصفي التحليلـي، حيــث قامت الدر سة بتحليل نتائج در اسات ســابقة

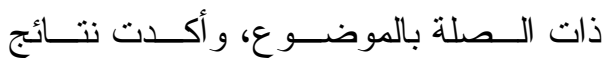
الدراسة أن الطلاب يشعرون بالأمان و التعلم

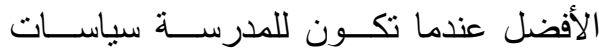

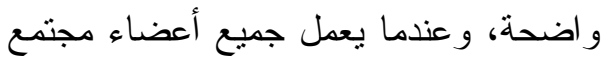
المدرسة من المديرين و المعلمين و الطــلاب و الآباء على حفظ حق كل طالب فــي بيئــة تعليمية آمنة. أما جونز (Jones, 2007) فقد أجرى دراسة هدفت إلى الكثف عن دور المدارس و إدار اتها في رسم سياسات وبـــر امج بيئــة 
بالبيئة المادية و المعنوية فيها، وقد أظهـرت

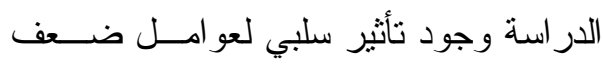

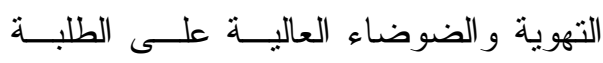
و المعلمين، إضافة إلى وجود علاقة موجبـــة

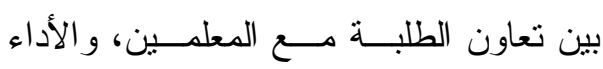
الوظيفي للمعلم و التحصيل الدر اسي للطلبة.

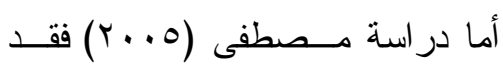
هدفت الى التعرف على مدى تأثثر البيئـات

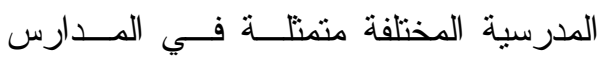
(الحكومية، و اللغات، و الإنجليزية) في مصر ،

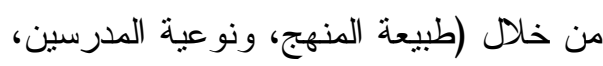

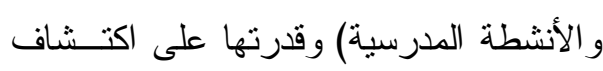

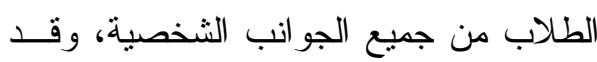

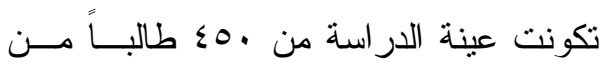
البيئات المدرسية المختلفة، استخدمت الباحثة المنهج الوصفي، وتوصلت الدراسة إلى عدة نتائج من أهمها: أن هناك علاقة دالـــة بــين

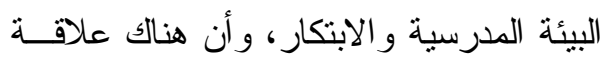
دالة بين البيئة المدرسية ومفهوم الذات، وأن

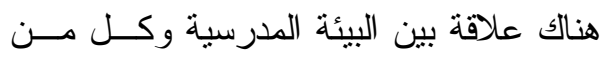

$$
\text { مفهوم الذات و الابتكار . }
$$

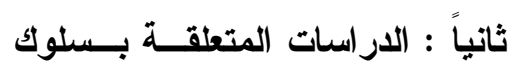

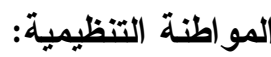

أجــرى أهميــت (Ahmet, 2016)

در اسة هدفت إلى كثثف أثز أنمــاط القيــادة

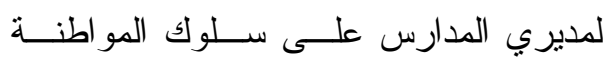
التتظيمية للمعلمين، اتبعت الدراسة المــنهج لهوري
المدرسية التي تساعد على اكتساب مهــار ات

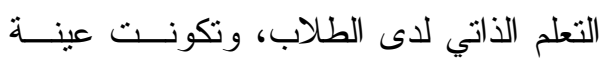

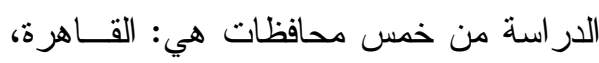

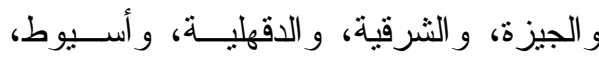
وشملت VT من مــديري مسـدارس التعلــيم الإعدادي و MVV من معلمي مدارس التعلــيم

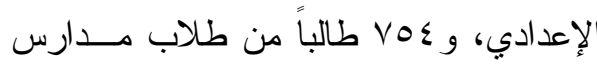

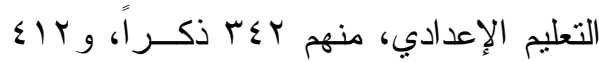

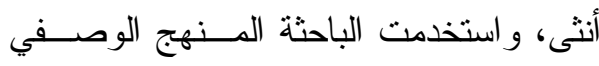

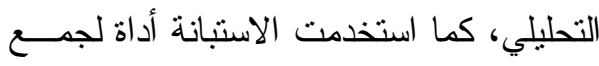
البيانات و المعلومات، وكان من أبرز النتائج التي توصلت إليها أن هناك نقص شديد فــي ني

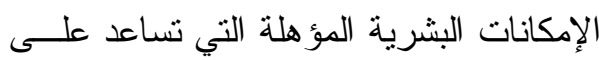

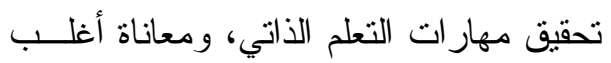

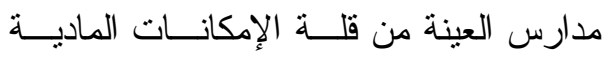

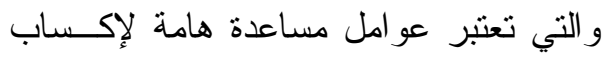

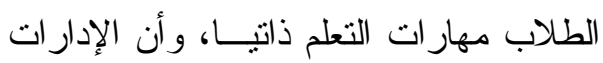

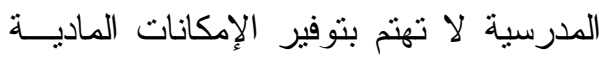

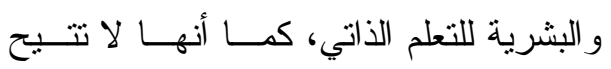
الوقت المناسب لذلك بالجدول المدرسي. وقد هدفت دراســة هيجنـز (2005)

(Higgins, بتأثير ات البيئة المدرسية في إطــار بحــث

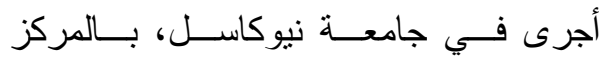
المدرسي للتعليم، وقد اتبعت الدراسة المنهج or الوصفي المسحي وتكونت العينــة مـــن مدرسة تم جمع المعلومات و البيانات المتعلقة 
لتتظيمية لاى معلمي مدارس التعليم الأساسي

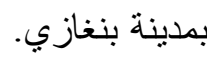

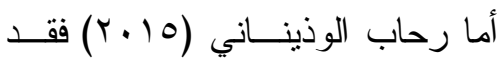

هدفت در استها الى التعــرف علــى ســلوك ابك الته المو اطنة التنظيمية وعلاقتها بالو لاء التنظيمي لاى مدير ات مدارس التعليم العام في مدينــة

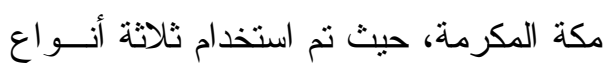
من المنهج الوصــفي (المـسـي و المقـــارن والارنباطي) و استخدمت استبانة تم توزيعها على مجتمع الدراسة الكامل مــن مــديرات المدارس بالتعليم العام بمدينة مكة المكرمسـة

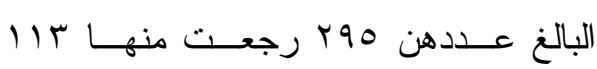

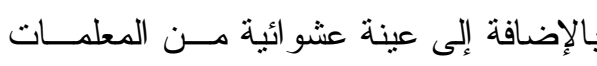

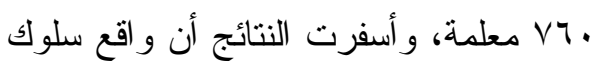

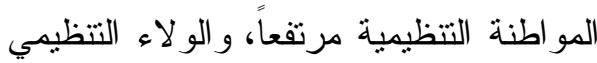
مرتفعاً كذللك، وتنين وجود علاقة ارتباطيــة بين الو لاء التنظيمي و أبعاده وسلوك المو اطنة النتظيمية و أبعادها.

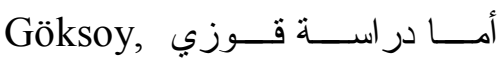

(Süleyman, 2014)

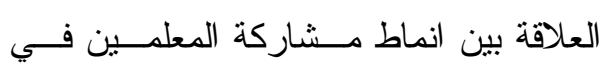
الادارة المدرسية بسلوك المو اطنة التتظيمية،

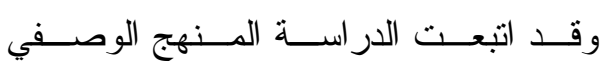

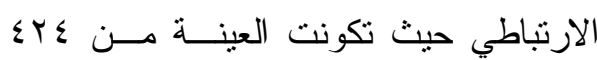

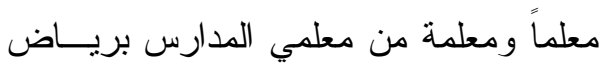

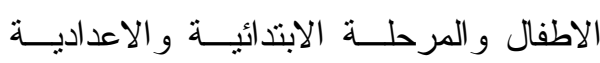

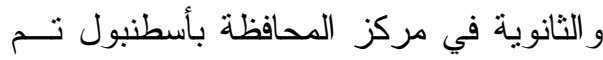

الوصفي الارنباطي، حيث تكونت العينة من

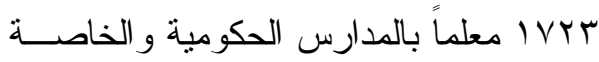
بحي كاديكيو بمحافظة اسطنبول بتركيا عـام

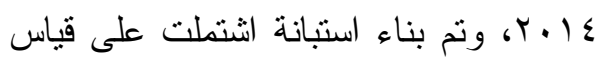

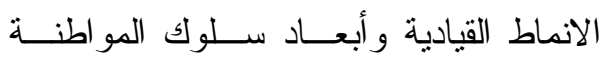

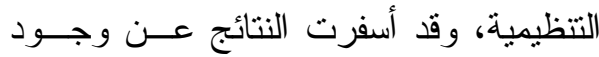
ارنباط كبير بين نمط القيادة التحويلية وسلوك وك وهن المو اطنة التظظيمية، وتنين وجود درجة كبيرة

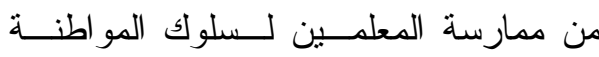

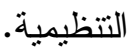
كما أجرى التزهوني وخديجة وبحيح

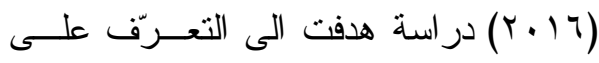

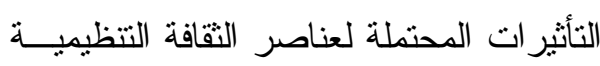

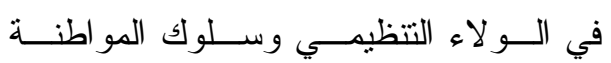

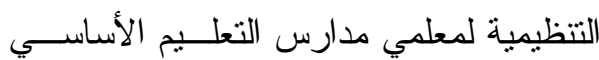

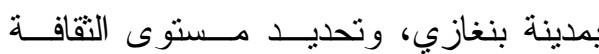
السائدة في مدارس التعليم الأساسي، وتأثير ها

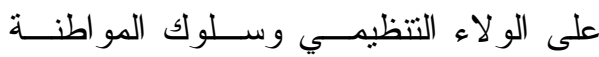

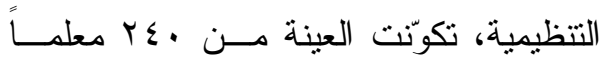

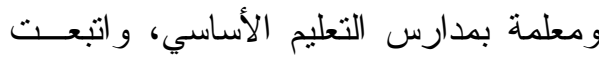
المنهج الوصفي الارتباطي و استخدمت ثلاثة

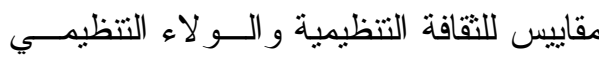
وسلوك المواطنة التتظيمية، و أسفرت النتائج على أن الثقافة التتظيمية السائدة في مـــدارس وسله

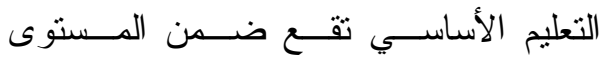
المتوسط، و لا نؤثز عناصر الثقافة التتظيمية

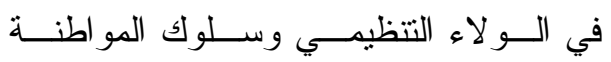


اللازمة للار اسة من خلال تطبيق مقياسـين

الاول لقياس ســلوك المواطنــة التتظيميــة و الثاني للقيادة التشاركية. وقد كثنفت نتــائج الدراسة عن وجود علاقة ارتباطية عالية بين سلوك القيادة التتظيمية و القياد النشاركية، كما تبين قدرة التتبؤ بأبعـــاد ســلـوك المو اطنــة التتظيمية الــستة مــن ممارســـات القبـــادة النشاركية حيث تدعم الابعاد الـستـة ظهــور سلوك القيادة التشاركية و أكثر الابعاد التـي ارتبطت مع ابعاد القيادة التـشـاركية كانـــت ممارسة تفويض السلطة ن وكان كل بُعد من ابعاد سلوك المو اطنة التتظيمية ينتبأ منفــرداً بدلالة احصائية عملية (حجم التــأثير) اكبـر على سلوك القيادة النتاركية و ابعادها.

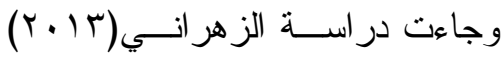

التي هدفت إلى الكثف عن ممارسة العدالــة التتظيمية لدى مـــديري المـــدارس الثانويـــة و علاقتها بمستوى سلوك المواطنة التتظيمية للمعلمين في محافظة المخو اة. و التي انتهجت المنهج الوصفي التحليلي، وتكونــت عينــة

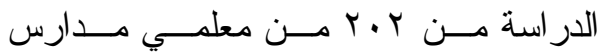
المرحلة الثانوية في محافظة المخو اة البــالغ

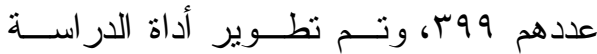

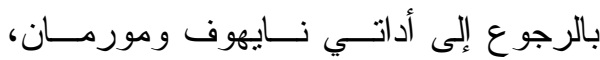
وتكونـــت مــن جـــئين : الأول للبيانـــات الاسـاسية، و الثاني لأبعاد العدالــــة التتظيميـــة

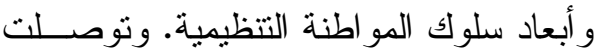

اختيار هم بأسلوب العينة العشو ائية البـسيطة وقد تم إعداد استبانة لقياس مشاركة المعلمين و المعلمات في الادارة المدرســية ومقيــاس

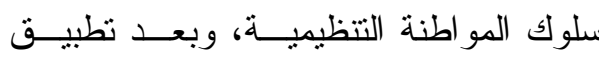
ادوات الدر اسة على العينة أســفرت النتــائج وجود فروق دالة إحصائياً في درجة مشاركة المعلمين بالإدارة المدرسية تعــزى للنــوع الاجتماعي لصالح الذكور، كما تبين وجـود فروق تعــى للعدــر لـــالح المعلمـين و المعلمات من الاعمار الاعلى كمــا تبــين وجود فروق تعزى للمؤهل العلمي لـصالح الماجستير و الاكتور اه، وتبــين أن مـستوى سلوك المو اطنة التتظيمية بدرجة عالية، بينما تبين مستوى المشـاركة بدرجــة منوســـة، وكثفت النتائج عــن وجــود علاقــة دالـــة احصائياً بين مستويات المشاركة فـي إدارة المدرسة وسلوك المو اطنة التتظيمية.

ودر اســـة بوستانــشي ( Bostanci

هدفت إلى التعرف علــى (Aynur, 2013 درجة التزام المعلمـين بـسلوك المواطنــة التتظيمية في المدارس الابتدائية و التتبؤ مــن خلاله بالممارسات الناجحة بالقيادة النشاركية

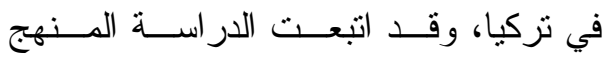

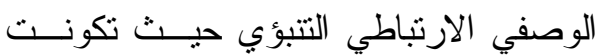
العينة من ع جس معلماً تم اختيار هم بالطريقة العثوائية من المدارس الابتدائية في مدينــة زونجولدالك بتركيــا، وتـــم جمــع البيانـــات 
وفي در اسة الباحثين التتكرت ويلماز

(Altinkurt\& Yilmaz, 2012)

هدفت إلى تحديد العلاقة بين مصادر ســلطة

مديري المدارس وسلوك المواطنة التتظيمية للمعلمين في المدارس الابتدائية فــي كتاهيــا بغرب نزكيا، اتبعت الدراسة المنهج الوصفي

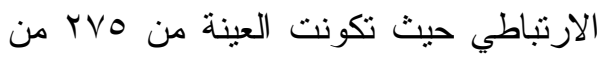
معلمي المدارس الابتدائية تم تصميم استبانة

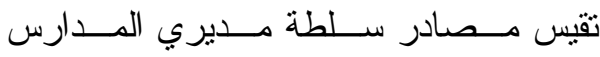

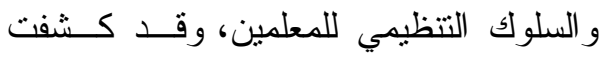
النتائج أن سلوك المو اطنة التتظيميــة عاليـــة وتبين أن ار اء المعلمين تغيرت باختلاف نوع المنصب وحقل الدراسة، وقد كان مسستوى لئن

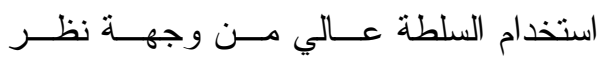
المعلمين، و ارتبط سلوك المو اطنة التتظيميــة

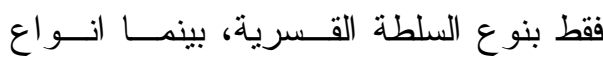
السلطة الاخرى مثــل الخبيــر و المتحدثـــة

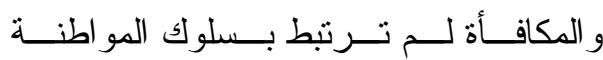

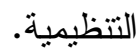

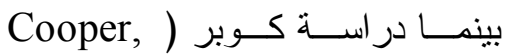

2010) هدفت إلى قياس العلاقة بين الفعالية

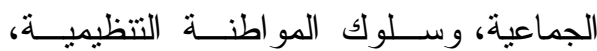

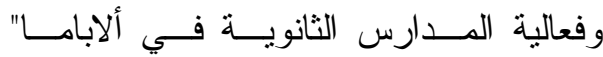

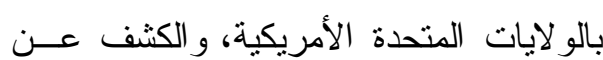
درجة إسهام سلوك المواطنة التتظيمية فـي ولي فعالية المدرسة، وقد أجريت هـــهـ الدراســـة

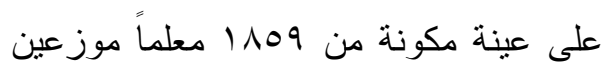

الدر اسة إلى النتائج التالية: يمــارس مــديرو

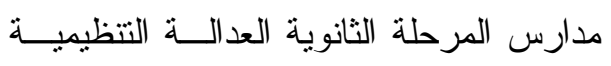

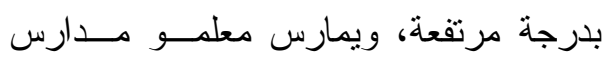

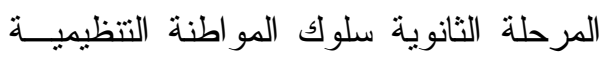
بدرجة مرتفعة جدا، وتوجد علاقــة ارتبــاط موجبة بين ممارسة مديري المدارس الثانوية

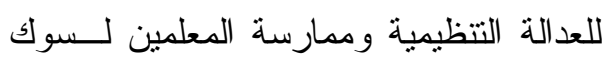
المو اطنة التتظيمية.

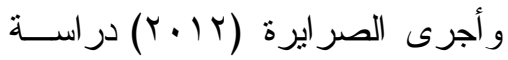
هدفت إلى التعرف على درجة العلاقة بـين

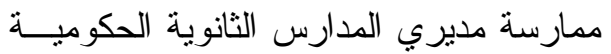

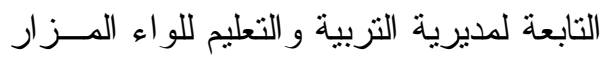

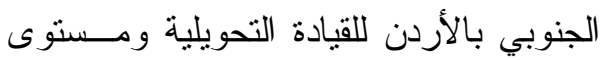

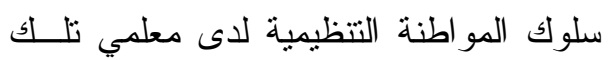

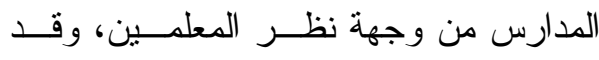

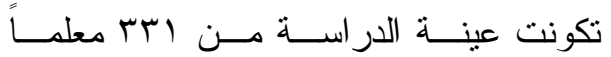

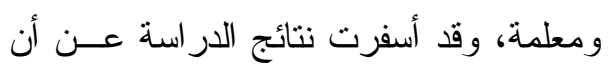
درجة ممارسة مــديري المـــارس للقيــادة التحويلية من وجهة نظـــر المعلمـين كــان

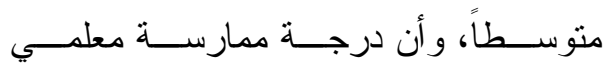
المدارس لسلوك المو اطنة التتظيميــة كــان منوسطا من وجهة نظر المعلمين أنفسهم، كما

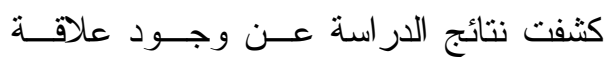
ارنباطية عالية وموجبة ودالة إحصائياً بـين درجة ممارسة مــديري المـــارس للقيــادة التحويلية ومستوى سلوك المو اطنة التتظيمية

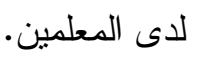


(Polat, 2009) (أمادراسة بولات

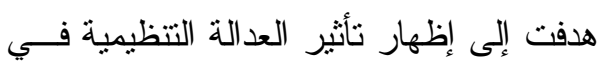
المدرسة في توضيح الثقة المدرسية، و الثقـــة في الإدارة وسلوك المواطنة التتظيمية، كذلك

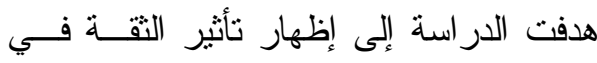

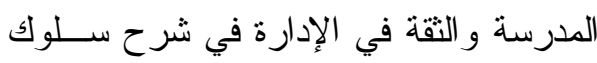

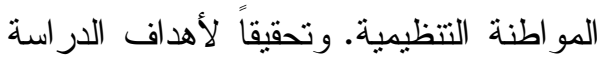
فقد دراسة الباحث باستخدام المنهج الوصفي ولهي

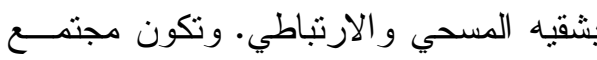
الدراسة من جميع معلمي المدارس الثانويـــة في تركيا ــوتمنلت عينة الدراسة في عينــة معنة

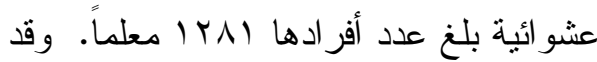
أظهرت نتائج الدراسة علاقة إيجابية هامسـة بين إدر الك المعلمين للعدالة التوزيعية و العدالة الإجر ائية و العدالة التفاعلية لتوضيح مفــــاهيم الثقة في المدرسة، و الثقة في الإدارة وسلوك ولئك

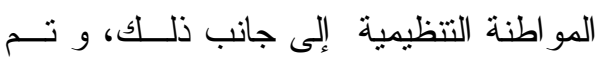
التأكيد أيضاً على أن تصور ات المعلمين للتقة في المدرسة، و الثقة في الإدارة مهمـــة فــي

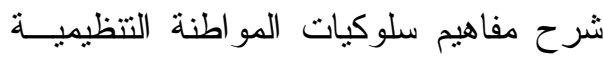
بطريقة ذات معنى.

منهج الدراسة وإجراياتها

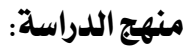
اتبعت الدر اسة المنهج الوصفي التحليلي

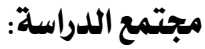

تكون مجتمع الدر اســـة مــن جميـع معلمي المدارس الحكومية بالمر احل التعليمية
على 0؛ مدرسة ثانوية عامة فــي ألابامــا.

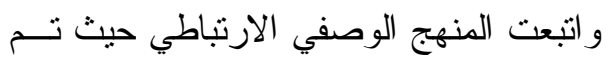
تجهيز مقاييس لقيــاس الفعاليــة الجماعيــة،

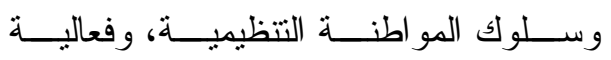
المدارس، و أظهرت نتائج الدر اسة عن وجود علاقة ذات دلالة بــين الفعاليــة الجماعيــة وفعالية المدرسة، فضلاً عن وجــــود إبــــهام

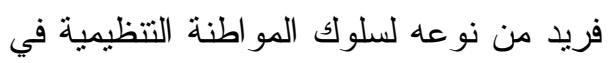
فعالية المدرسة.

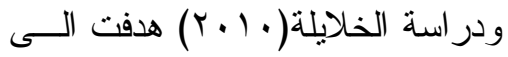
التعرّف على درجة ممارسة مديري مدارس محافظة الزرقاء ومدير اتها للقيادة التحويليـــة وعلاقتها بسلوك المو اطنة النتظيمية لمعلمــي لهي تلك المدارس ومعلماتها، اتبعــت الدراســة

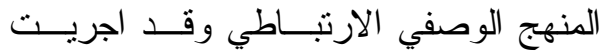

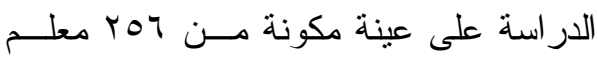
ومعلمة. نم بناء استبانة تقيس ابعاد القبـادة

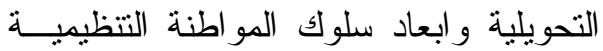
و أظهرت النتائج وجــود علاقـــة ارتباطيــة موجية ومتوسطة ودالة إحصائيا بين القيــادة التحويلية بأنماطها الأربعة متفرقة ومجتمعة، وسلوك المو اطنة التتظيمية للمعلمين بأربعــة

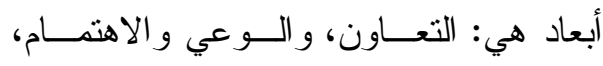

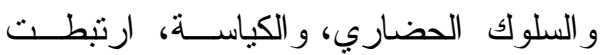

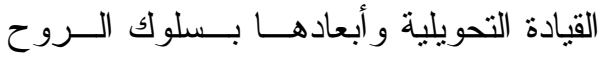
الرياضية بعلاقة ضعيفة وسالبة. 


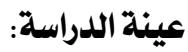

تم توزيع أداة الدراسة علــى عينـــة

الثلاث في محافظة أضــم، وعــددهم(مبرم)

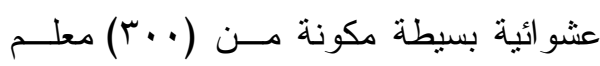

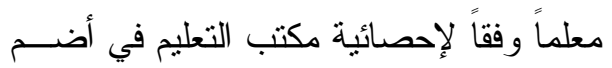

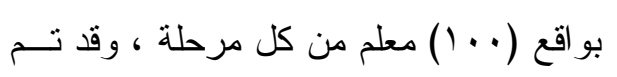

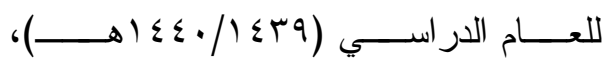

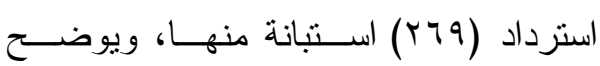
الجدول (1) الاستبانات الموزعة و المستردة و العدد المفقود و النهائي.

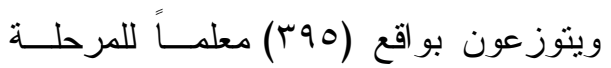

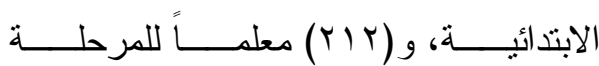

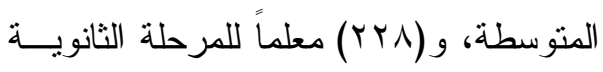
(ملحق رقم 0).

جدول (1)

أعداد الاستبانات الموزعة والمستردة والمفقودة والعدد النهائي

\begin{tabular}{|c|c|c|c|c|c|}
\hline \multicolumn{2}{|c|}{ العدد النهائي } & \multirow{2}{*}{ المسترد } & \multirow{2}{*}{ المفقود } & \multirow{2}{*}{ العدد الموزع } & \multirow{2}{*}{ المرحلة } \\
\hline النسبة/المجتمع & العدد & & & & \\
\hline$\%$ \%r,o & $9 \pi$ & $9 \pi$ & $\mathrm{V}$ & $1 \ldots$ & الابتد ائية \\
\hline$\% r \wedge, r$ & NI & 人) & 19 & $1 \ldots$ & المتوسطة \\
\hline$\%$ \%,V & 90 & 90 & 0 & $1 \ldots$ & الثانوية \\
\hline$\% r r, r$ & r7q & $r 79$ & 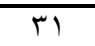 & $r \ldots$ & الإجمالى \\
\hline
\end{tabular}

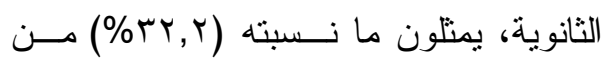

يتضتح مــن الجــدول (1) أنـــه تــم

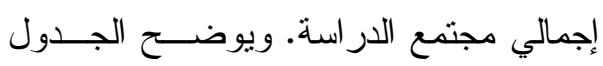

استرداد (Yq9) استبانة موز عين بو اقع (r9)

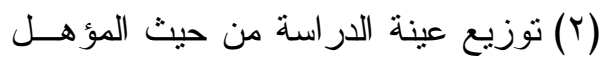

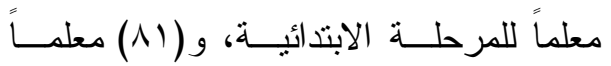
للمرحلة المتوسطة، و (90) معلماً للمرحلـة وعدد سنوات الخبرة:

جدول (r)

خصائص عينة الدراسة من حيث المؤهل وعدد سنوات الخبرة

\begin{tabular}{|c|c|c|c|}
\hline النسبة & العدد & الفئة & المتغير \\
\hline$\% \wedge \wedge, \wedge$ & $r+q$ & بكالوريوس & \multirow{3}{*}{ المؤهل العلمي } \\
\hline$\% \backslash 1, r$ & $r$. & در اسات عليا & \\
\hline$\% 1 \ldots$ & r79 & الإجمالي & \\
\hline$\% 10,7$ & $\varepsilon r$ & أقل من ه سنو ات & \multirow{4}{*}{ عدد سنو ات الخبرة } \\
\hline \%rr & $\Lambda 7$ & من • إلى أقل من • 1 سنوات & \\
\hline$\% \circ r, \varepsilon$ & $1 \leq 1$ & من ـ اسنو ات فأكثر & \\
\hline$\% 1 \ldots$ & r7q & الإجمالي & \\
\hline
\end{tabular}




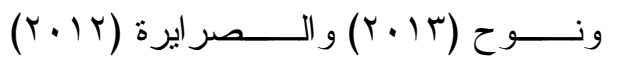

و القحطاني (Y (Y). (Y). وقد تكونت الاسـتبانة

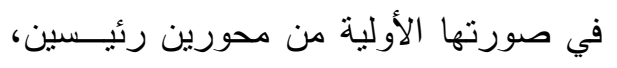

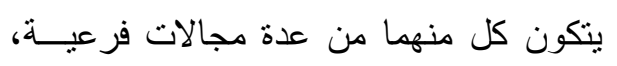

$$
\text { وذللك على النحو التالي: }
$$

محور جودة البيئة المدرسية، وتكون مسن (آ) فقرة موزعة على ســبعة مجــالات،

وهي:

1. التميز القيادي، ويتضمن (1) فقرة. r. الثقافة المؤسسية، ويتضمن (1) فقرة. r. الجودة، ويتضمن (؟) فقرات.

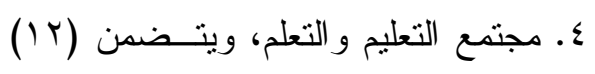

$$
\text { فقرة. }
$$

هـ التتمية المهنية، ويتضمن (؟) فقرات.

7. المدرسة الرقمية، ويتضمن (9) فقر ات.

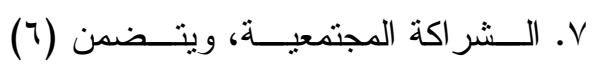

$$
\text { فقر ات. }
$$

محور المواطنة التنظيمية، وتكون من (ع ب) فقرة موزعة على خمسة مجالات، وهي: ا ـ الإيثار ، ويتضمن (ع) فقر ات.

$$
\text { r. الكياسة، ويتضمن (0) فقر ات. }
$$

r. الروح الرياضية، ويتضمن (0) فقرات.

$$
\text { ع. وعي الضمير، ويتضمن (0) فقر ات. }
$$

0. الــسلوك الحـــضاري، ويتــضمن (0)

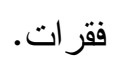

يتبين من الجدول (Y) أن معظم أفر اد

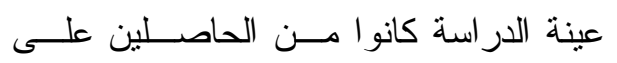

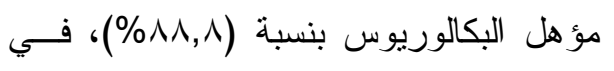

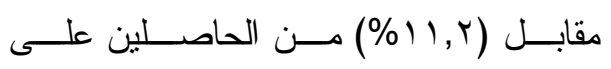

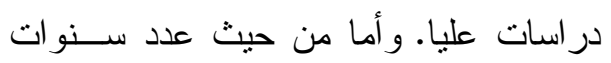
الخبرة في التدريس، فقد تبين أن (ع,_or\%)

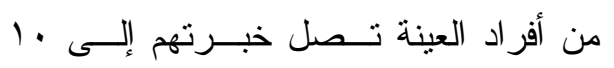

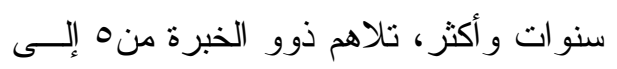

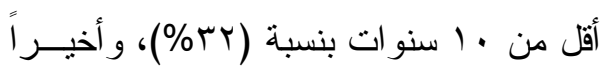

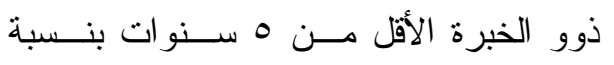
. (\%)०, 7$)$

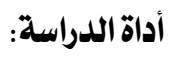

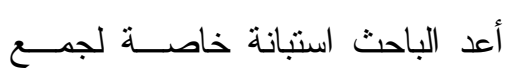
البيانات اللازمة للار اسة، وذلك بعد مر اجعة الأدبيات و الدر اســات الــــابقة ذات الــصلة

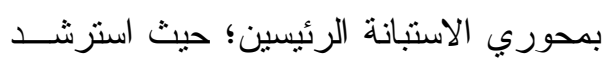
الباحث في بناء المحور الأول الخاص بجودة

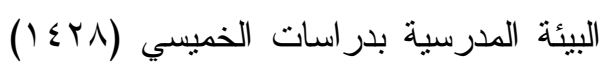

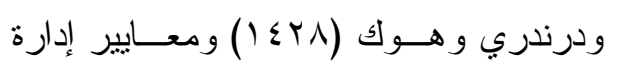

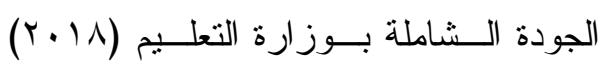
و النسخة المطورة لمعايير الاعتماد المؤسسي لوني

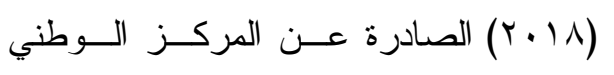

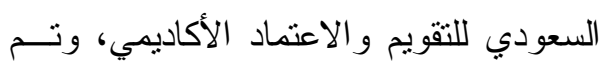

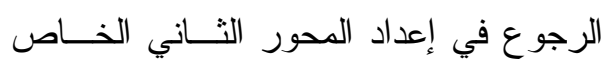
بالمواطنة التنظيمية للعديد مــن الدراســات

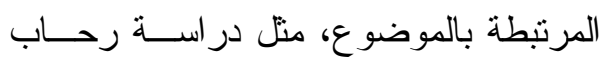

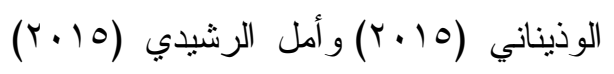


وضوح الصياغة اللغوية، دع حذف و إضافة

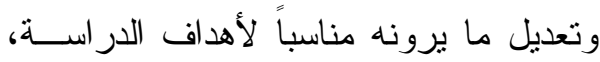
وكذلك إبداء ر أيهم في المقيــاس المستستخدم للاستجابات. وبعد استرجاع الاستبانات نتين اتفاق المحكمين على حذف مجـــال الثقافــة المؤسسية من المحور الأول الخاص بجـــودة

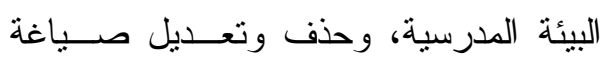
بعض الفقرات في المحورين، وبعد إجــر اء

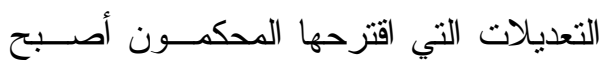

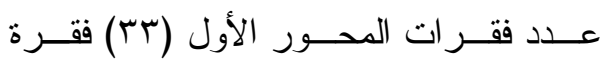
موزعة على ستة مجالات؛ بينما أصبح عدد الاول

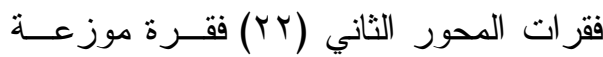

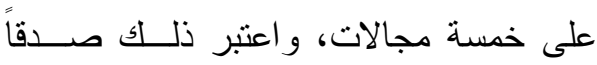
ظاهريًا للاسنبانة. ثانياً: صدق الاتساق الاخلي: تم التأكد من صدق الاتساق الــــاخلي للاستبانة باستخدام معاملات ارتباط بيرسون

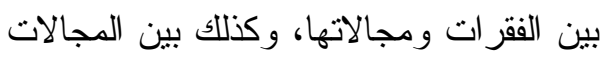
و الدرجة الكلية للمحور، وذلك بعد النطبيــق على عينة استطلاعية مكونة من (•r) معلماً من المر احل التعليمية الثناث (تم اســتبعادهم

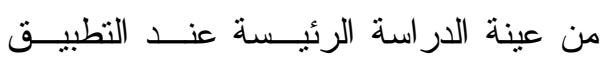

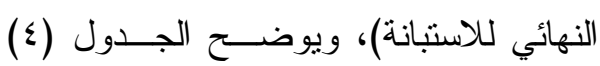

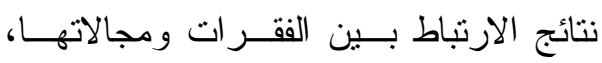

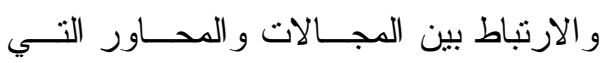
تتنمي لها.
وقد تم تحديد درجة الاستجابة علـى لقى

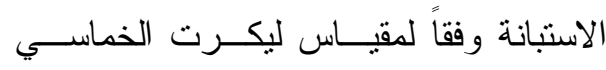

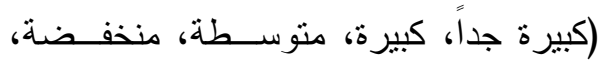

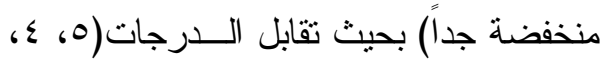

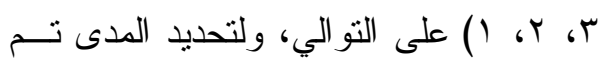

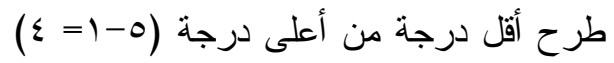

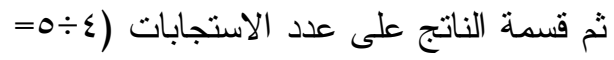

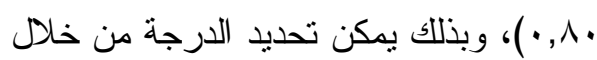

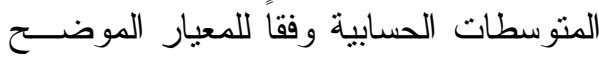
بالجدول (r)

جدول (r)

\begin{tabular}{|c|c|c|}
\hline \multicolumn{3}{|c|}{ معيار الحكم على الاستجابات } \\
\hline المتوسط الحسابي & 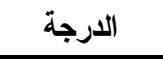 & b \\
\hline من r, إ إلى 0 & كبيرة جداً كبيراً & 1 \\
\hline من 乏,r إلى أقل من r, & كبيرة & r \\
\hline من ؟, r, إلى أقل من ع,r & متوسطة & r \\
\hline من ^, إ إلى أقل من T, T & منخفضة & $\varepsilon$ \\
\hline من إلى أقل من A, & منخفضة جداً & 0 \\
\hline
\end{tabular}

صدق وثبات الاستبانة بالطرق التالية: أولاً: الصدق الظاهري:

للتأكد من الصدق الظاهري للاستبانة تم عرضها على مجموعة مــن المحكمـين المتخصصين (ملحق رقم ب)، وذلك لإبـــــاء

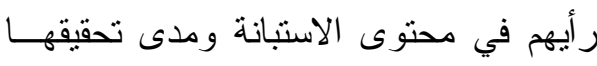
لأهداف الدراسة، وتحديد ملائمة و انتماء كل

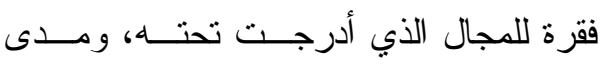




\section{جدول (؛)}

معاملات ارتباط بيرسون بين الفقرات ومجالاتها (ن= بـ)

\begin{tabular}{|c|c|c|c|c|c|c|c|c|c|c|c|c|c|}
\hline \multicolumn{14}{|c|}{ المحور الأول: جودة البيئة المدرسية } \\
\hline \multicolumn{2}{|c|}{ الثراكة المجتمعية } & \multicolumn{2}{|c|}{ الرقمية } & \multicolumn{3}{|c|}{ التنمية المهنية } & \multicolumn{2}{|c|}{ التعليم و التعلم } & \multicolumn{3}{|c|}{ 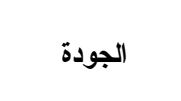 } & \multicolumn{2}{|c|}{ التميز القيادي } \\
\hline الارتباط & 3 & الارتباط & 5 & \multicolumn{2}{|c|}{ 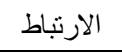 } & 3 & الارتباط & 3 & \multicolumn{2}{|c|}{ الارنتاط } & c & 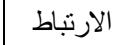 & 3 \\
\hline$*, V r$. & r. & $*, 719$ & $r \varepsilon$ & \multicolumn{2}{|c|}{ *,VAr } & 19 & $*, \wedge 01$ & $1 \varepsilon$ & \multicolumn{2}{|c|}{ *,Tr. } & 9 & $\because \cdot, \vee \wedge q$ & 1 \\
\hline$\because,, 100$ & r & $*, V \cdot r$ & ro & \multicolumn{2}{|c|}{ *., $\vee \neg \leqslant$} & r. & $*$ •,人TT & 10 & \multicolumn{2}{|c|}{$* \cdot, \wedge \mathrm{VV}$} & 1. & $\because \cdot, \wedge \circ \leqslant$ & r \\
\hline$\because, \vee \vee 97$ & r & $*, 91 \mathrm{~V}$ & rq & \multicolumn{2}{|c|}{$\because \cdot, \wedge 9 \Gamma$} & r) & $*, \wedge \cdot \varepsilon$ & 17 & \multicolumn{2}{|c|}{$* \cdot, \wedge \leqslant V$} & 11 & $\because, \wedge r V$ & r \\
\hline \multirow[t]{5}{*}{ 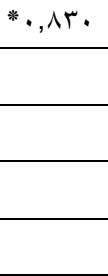 } & 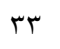 & $*, \wedge 07$ & Tr & \multicolumn{2}{|c|}{$\because \cdot, \wedge T \mathrm{~V}$} & rt & $*, \wedge r q$ & iv & \multicolumn{2}{|c|}{$*, 9.0$} & ir & $\because \cdot, \wedge, 7$ & $\varepsilon$ \\
\hline & & $*, \wedge 09$ & r^ & \multicolumn{2}{|c|}{$* \cdot, \wedge \cdot \wedge$} & r & *, Tr. & 11 & \multicolumn{2}{|c|}{$*, 9 \mu 1$} & ir & $\because, 707$ & ○ \\
\hline & & שr, • & \multicolumn{3}{|l|}{9} & & & & & & & $\because \cdot, T V V$ & 7 \\
\hline & & & & & & & & & & & & $\because, \wedge \vee \vee$ & $\checkmark$ \\
\hline & & & & & & & & & & & & $\because \cdot, 771$ & $\wedge$ \\
\hline \multicolumn{14}{|c|}{ المحور الثاني: المو اطنة التنظيمية } \\
\hline \multicolumn{2}{|c|}{ السلوك الحضاري } & \multicolumn{3}{|c|}{ و وعي الضمير } & \multicolumn{3}{|c|}{ الروح الرياضية } & \multicolumn{3}{|c|}{ الكياسة } & & \multicolumn{2}{|l|}{ الإيثار } \\
\hline الارتباط & 3 & الارتباط & \multicolumn{2}{|c|}{ s } & \multicolumn{2}{|c|}{ الارنباط } & 3 & \multicolumn{2}{|c|}{ الارنباط } & 3 & & الارنباط & 3 \\
\hline$\because, 91$. & or & $* \cdot, q \cdot V$ & \multicolumn{2}{|c|}{$\leqslant V$} & \multicolumn{2}{|c|}{$\because \cdot, \cdot \cdot 9$} & $\varepsilon r$ & \multicolumn{2}{|c|}{$*, \wedge \leq r$} & rV & & $*, \vee \vee \wedge \wedge$ & $r \varepsilon$ \\
\hline$*, \wedge \leq \varepsilon$ & or & *, ANr & & & & $9 \cdot 1$ & $\leq r$ & $*, 9$ & & rᄉ & & $\because \cdot, \wedge T$ & ro \\
\hline *, & $0 \leq$ & $*, \wedge \pi r$ & & & & 941 & $\varepsilon \varepsilon$ & $*, 9$ & & rq & & 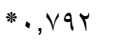 & די \\
\hline$*, \wedge) \leqslant$ & 00 & $*$ *, ^or & & & & $\wedge$ ^९ & $\leqslant 0$ & $*, 9$ & & $\varepsilon$. & & & \\
\hline & & $*, \wedge r \wedge$ & & & & 9.9 & $\leq 7$ & $*, \wedge$ & & 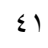 & & & \\
\hline
\end{tabular}

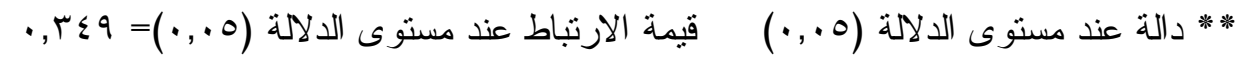

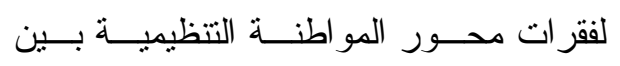

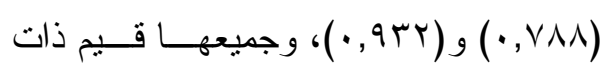

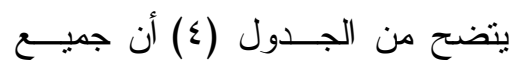

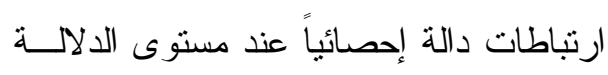

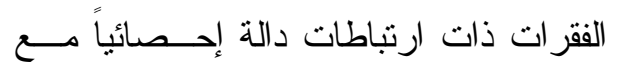

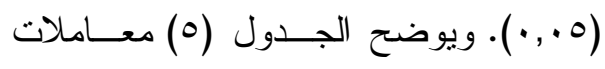

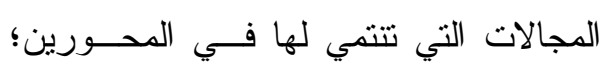
الارتباط بين المجالات ومحاورهــا، وبــين حيث تراوحت قيم الارتباط لفقرات محسـور و (اس 9 , )؛؛ بينما تز اوحت قـيم الارتبــاط المحاور و الدرجة الكلية للاستبانة: 


\section{جدول (•)}

معاملات ارتباط بيرسون بين المجالات ومحاورها، وبين المحاور

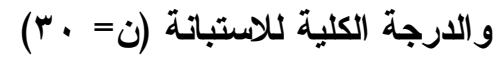

\begin{tabular}{|c|c|c|c|}
\hline الارتباط مع الأداة & الارتباط مع المحور & المجالات & المحور \\
\hline \multirow{6}{*}{$* \cdot, 9 \leqslant r$} & $*, \wedge Y_{0}$ & التميز القيادي & \multirow{6}{*}{ المحور الأول: جودة } \\
\hline & $*, q, \varepsilon$ & الجودة & \\
\hline & $*, \wedge r q$ & التعليم و التعلم & \\
\hline & $*, \wedge 9 \leqslant$ & التتمبة المهنية & \\
\hline & $*, \Delta r)$ & الددرسة الرقمية & \\
\hline & $*, \wedge \varepsilon$. & الشر اكة المجتمعية & \\
\hline \multirow{5}{*}{$*, 90$. } & $*, \wedge 1$. & الإيثار & \multirow{5}{*}{ المحور الثاني: المواطنة } \\
\hline & $*, 9 \leq 7$ & الكياسة & \\
\hline & $* .977$ & الروح الرياضية & \\
\hline & $*, \wedge 71$ & وعي الضمير & \\
\hline & $*, \wedge \vee q$ & السلوك الحضاري & \\
\hline
\end{tabular}

* دالة عند مستوى الدلالة (0. . . ) قيمة الارتباط عند مسنوى الدلالة (0., •) =

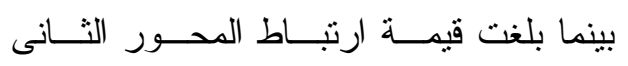
(90.90. •)، وكانت جميع القيم دالة إحـــائيًاً

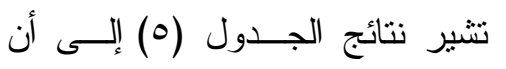

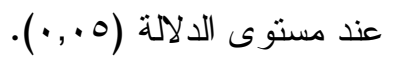
جميع المجالات كانت ذات ارنباطات دالـــة ثالثاً: ثبات الاستبانة

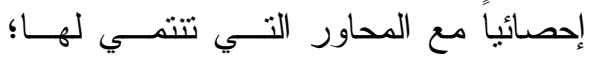

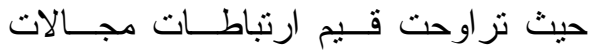
تم التأكد من ثبات الاستبانة باســتخدام محور جودة البيئة المدرسية بين (المبر, •)

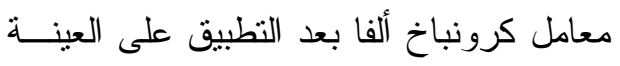

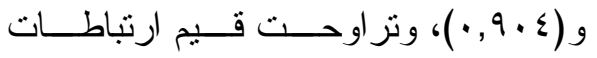

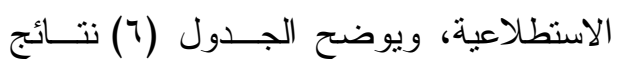

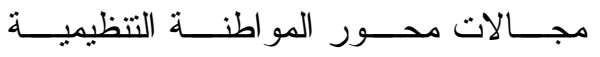
للمجالات و المحاور و الاستبانة ككل:

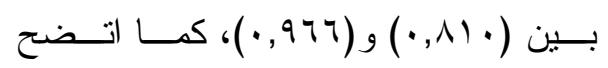

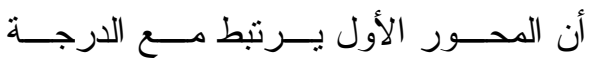

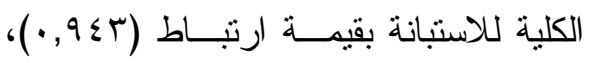


جدول (†) ثبات الاستبانة باستخذام معامل كرونباخ ألفا (ن= . بآ)

\begin{tabular}{|c|c|c|c|}
\hline الثبات & عدد الفقرات & المجالات & المحور \\
\hline$\cdot, q \cdot r$ & $\wedge$ & التميز القيادي & \multirow{7}{*}{ المحور الأول: جودة } \\
\hline מדr & 0 & الجودة & \\
\hline$\cdot, 911$ & 0 & التعليم و التعلم & \\
\hline$\cdot, 9 \leq r$ & 0 & التتمية المهنية & \\
\hline$\cdot, \wedge \wedge \wedge$ & 7 & المدرسة الرقمية & \\
\hline$\cdot, 9 \cdot r$ & $\varepsilon$ & الثر اكة المجتمعية & \\
\hline$\cdot, 9 \leq 7$ & 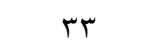 & الثبات لكلي للمحور الأول & \\
\hline$\cdot, \wedge \wedge \varepsilon$ & r & الإيثار & \multirow{6}{*}{ المحور الثاني: المو اطنة } \\
\hline$\cdot, 901$ & 0 & الكياسة & \\
\hline$\cdot, 9 \vee \wedge$ & 0 & الروح الرياضية & \\
\hline., $9 Y 0$ & 0 & وعى الضمير & \\
\hline., 940 & $\varepsilon$ & السلوك الحضاري & \\
\hline$\cdot, 900$ & rt & الثبات لكلي للمحور الثاني & \\
\hline$\cdot, 971$ & 00 & \multicolumn{2}{|c|}{ ثبات الأداة ككل } \\
\hline
\end{tabular}

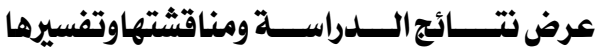

عرض ومناقثتة وتفـسير نتــائج الـسؤال

الأول:

نص السؤال الأول على: ما درجـــة

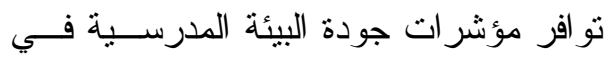

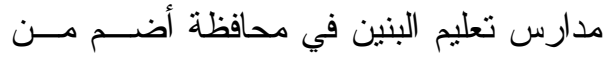

وجهة نظر المعلمين؟

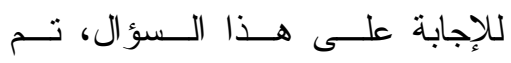

استخر اج المتوسطات الحسابية، و الانحر افات

المعيارية ورتبة ودرجة كـلـ مجــال مـنـ

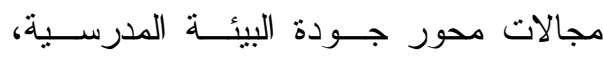

وتزتيبها تتازلياً وفقاً لمتوسطاتها الحسسابية،

$$
\text { و الجدول (V) يوضح هذه النتائج: }
$$

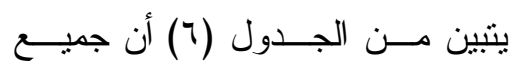

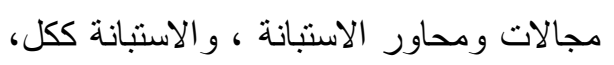

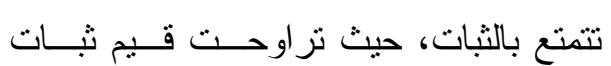

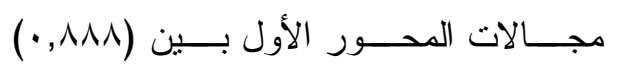

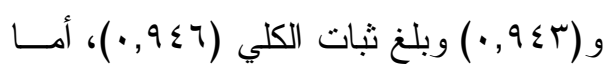

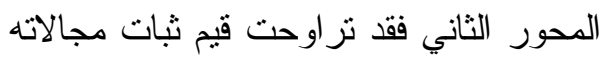

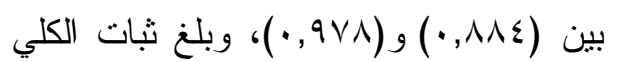

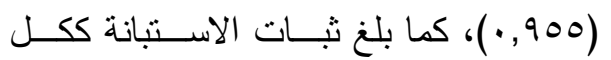
( (ا797 •)، وهي قيم مرتفعة تطمئن إلى ثنات

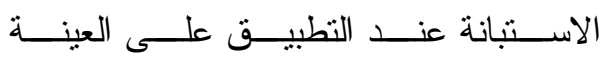
المستهدفة. 
جدول (V) المتوسطات الحسابية والانحر افات المعيارية والارجة لمجالات محور جودة البيئة المدرسية مرتبة تنازلياً

\begin{tabular}{|c|c|c|c|c|c|}
\hline الدارجة & الرتبة & الآحر اف المعياري & المتوسط الحسابي & المجالات & م \\
\hline كبيرة & 1 & $\cdot, \wedge$. & $r, \wedge)$ & الثر اكة المجتمعية & 7 \\
\hline كبيرة & r & $\cdot, 10$ & r,Vr & التميز القيادي & 1 \\
\hline كبيرة & r & $\cdot$, or & $r, 09$ & التعليم و التعلم & r \\
\hline كبيرة & $\varepsilon$ & $\cdot, \wedge 9$ & r,or & الجودة الجو & r \\
\hline كبيرة & 0 & $\cdot, 99$ & r,or & التنمية المهنية & $\varepsilon$ \\
\hline متوسطة & 7 & $\cdot, v r$ & ס ס, ז & المدرسة الرقمية & 。 \\
\hline \multicolumn{2}{|c|}{ كبيرة } & $\cdot, \wedge \vee$ & $r, 09$ & حور جودة البيئة المدرسية & \\
\hline
\end{tabular}

بدرجة متوسطة؛ حيث بلغ المتوسط الحسابي

يشير الجــدول (V) إلــى أن تـــو افر

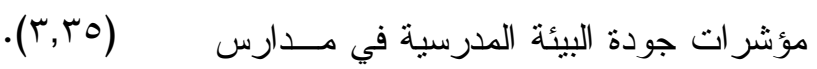

ويعزو الباحث الدرجة الكبيرة لجودة

تعليم البنين في محافظة أضم من وجهة نظر

البيئة المدرسية إلى الجهـــود التــي تبـــلها

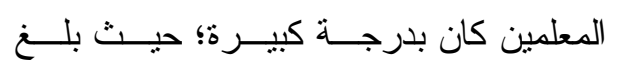

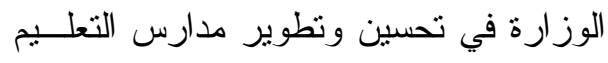

المتوسط الحسابي العــام للدحــور (r,09)

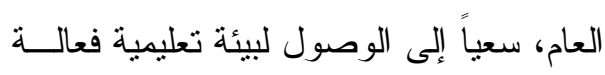

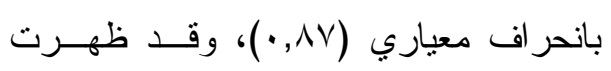

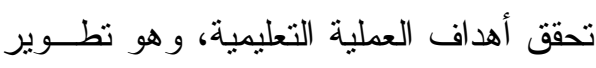
خمسة مجالات بدرجة تو افر كبيرة ومجــال يشمل جميع الجوانب المتعلقة بالعمل، بــدءاً و احد بدرجة تو افر منوسطة. وجـــاء مجـــال

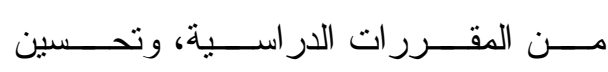

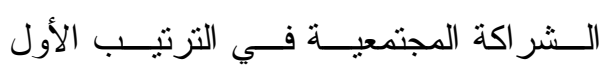

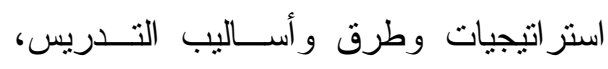

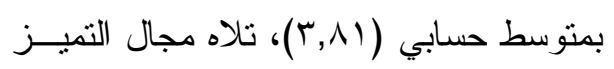

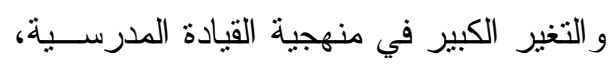

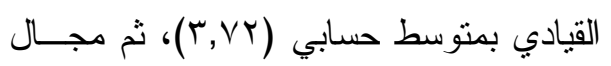

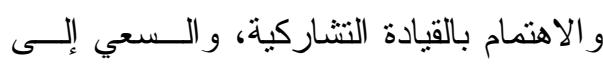

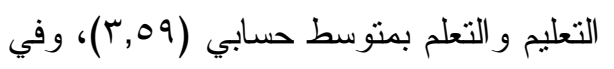

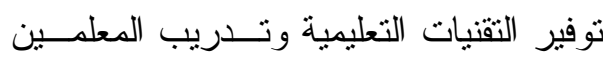
الترنيب الر ابع مجال الجودة بمتوسط حسابي

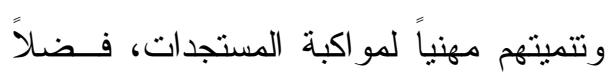

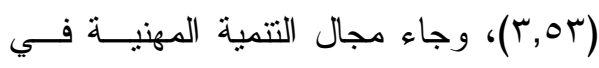
عن تطبيق معايير وفرق الجــودة و اعتمــاد

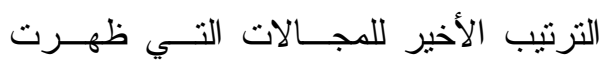

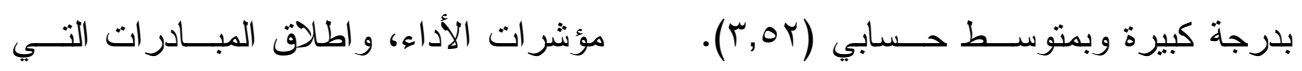

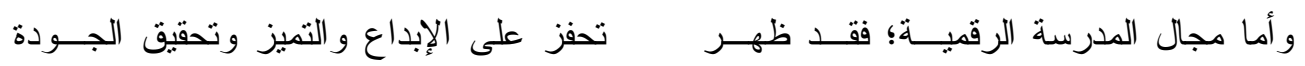




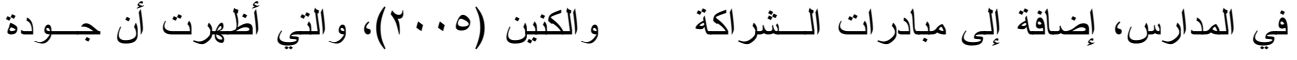

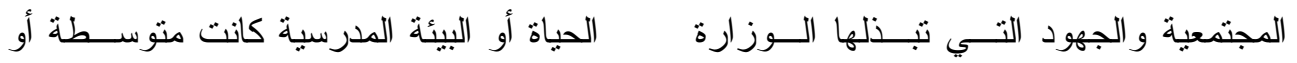

$$
\begin{aligned}
& \text { لتحقيق شر اكة إيجابية فاعلة بـين المدرســة تعاني من القصور . } \\
& \text { وفيما يلي توضيح نتائج كل مجــال }
\end{aligned}
$$

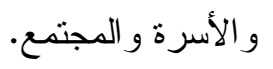

$$
\begin{aligned}
& \text { وتختلف هذه النتائج مع ما أظهرتــهـ بالتفصيل: }
\end{aligned}
$$

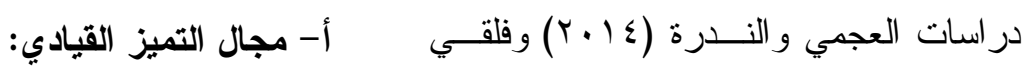

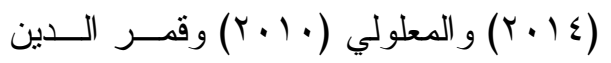

جدول (^)

\begin{tabular}{|c|c|c|c|c|c|}
\hline 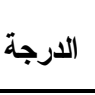 & 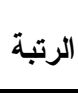 & الالمعيار اف & المستوسط & 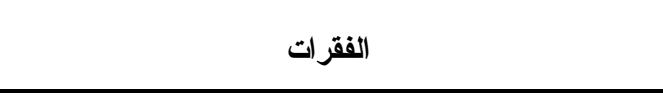 & 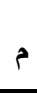 \\
\hline كبيرة & 1 & $\cdot, 9$. & r,q1 & رؤية مدرستي ورسالتها و اضحة ومعلنة. & 1 \\
\hline 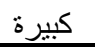 & r & $\cdot, \wedge$. & r, q. & يفوض قائد مدرستي بعض الصدلاحيات للعاملين. & $\circ$ \\
\hline 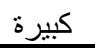 & r & $\cdot, 90$ & r, , & لاى مدرستي خطة تتفيذية محددة. & $r$ \\
\hline 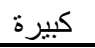 & $\varepsilon$ & $\cdot, \wedge)$ & $r, \mathrm{r}$ & يتسم توزيع المهام في مدرستي بالعدالة. & 7 \\
\hline كبيرة & 0 & $\cdot, 91$ & $r, v i$ & يشكل قائد مدرستي فريقاً لإدارة الأزمات بالمدرسة. & $\wedge$ \\
\hline 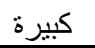 & 7 & $\cdot, \wedge$. & $r, v \cdot$ & يُفعَل قائد مدرستي اللجان المدرسية طو ال العام. & 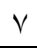 \\
\hline كبيرة & $\mathrm{V}$ & $\cdot, \wedge 9$ & $r, 0 \leqslant$ & تتشر مدرستي ثقافة التغيير بين العاملين. & $\varepsilon$ \\
\hline 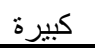 & $\Lambda$ & $\cdot, \wedge)$ & ऍ, §ᄉ & بشترك جميع المنسوبين في صياغة رؤية ورسالة مدرستي. & r \\
\hline \multicolumn{2}{|c|}{ كبيرة } & $\cdot, \wedge 0$ & r,VT & الدرجة الكلية لمجال التميز القيادي & \\
\hline
\end{tabular}

المتوسطات الحسابية والاحر افات المعيارية والارجة لمجال التميز القيادي مرتبة تنازلياً

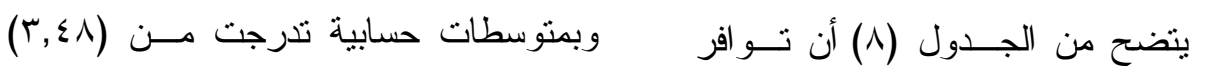

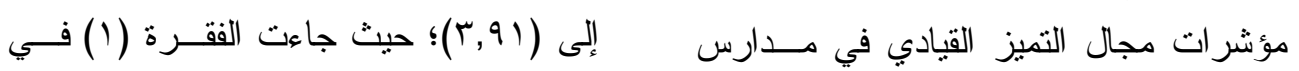

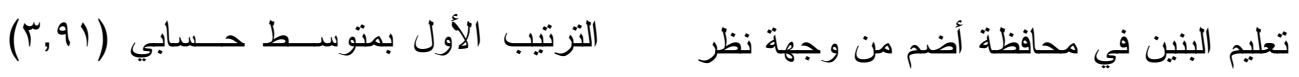

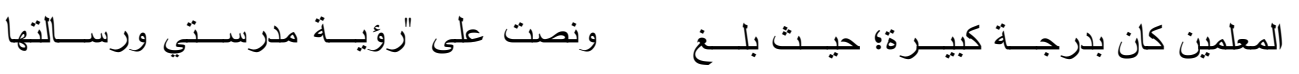

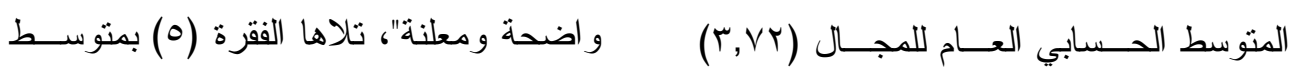

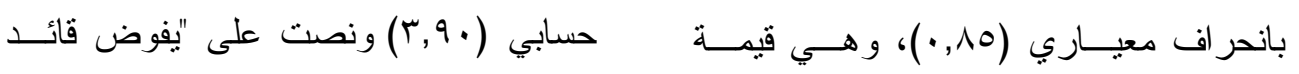

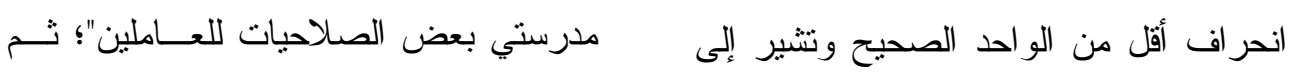

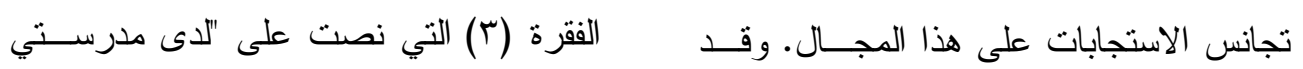

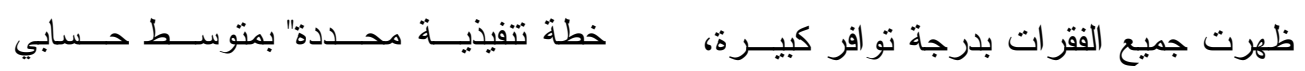


دراسي، كما أن معظم المدارس تتبنى رؤية

( ( , V^) ورسالة واضحة ومعلنة تركز على التغييــر

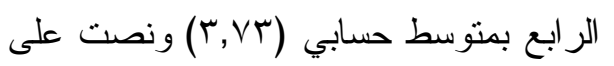

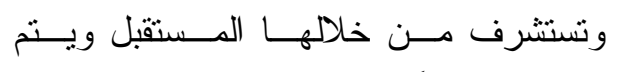
"يتسم توزيع المهام في مدرسنتي بالعدالـــة"، صياغتها غالباً بالتعاون مع جميع العـاملين تلاها الفقرة (^) التي نصت على لئى "يشكل قائد

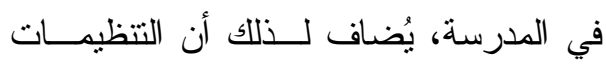

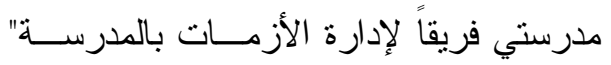
المدرسية أصبحت تعطي مزيداً من الاهنمام

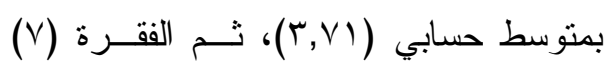

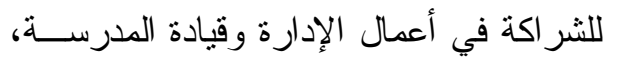

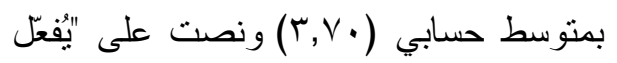
و هو ما تجسد في مزيد من الصلاحيات التي قائد مدرستي اللجان المدرسية طو ال العــام"،

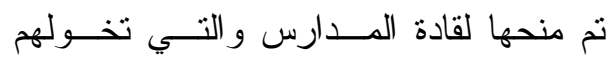

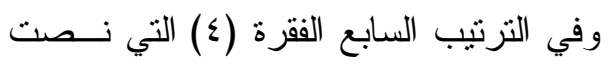

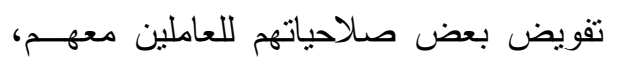

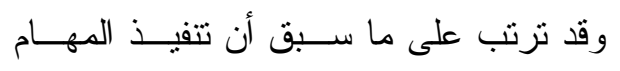

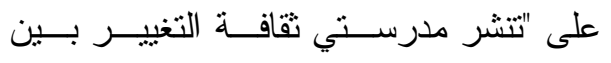

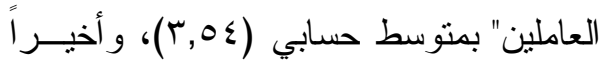
المدرسية أصبح يركز على العمل التعـاوني القائم على تكوين فرق عمل ولجان مدرسية

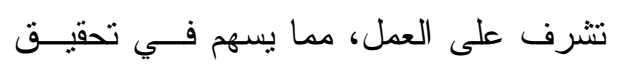

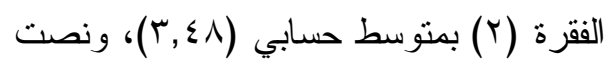
على "يشترك جميع المنسوبين في صـيـياغة رؤية ورسالة مدرستي". التميز القيادي.

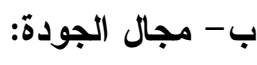

ويعزو الباحث الدرجة الكبيرة لمجال التميز القيادي إلى أن جميع المدارس لــديها

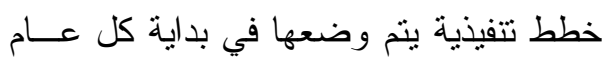
جدول (a)

المتوسطات الحسابية والاحمر افات المعيارية والارجة لمجال الجودة مرتبة تنازلياً

\begin{tabular}{|c|c|c|c|c|c|}
\hline | الارجة & الزتبة & 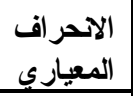 & الحسابي & الفقرات & م \\
\hline 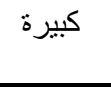 & 1 & $\cdot$, Vo & $r, \vee q$ & تالعتداء. مدرستي المؤشرات الموثوق فيها لقياس مستوى & $\pi$ \\
\hline كبيرة & r & $\cdot, \times 1$ & $r, T \mathrm{~V}$ & تتمي مدرستي ثقافة الجودة لدى منسوبيها. & 9 \\
\hline 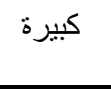 & r & $\cdot, 94$ & r,or & تضع مدرستي مبادرات ابداعية لتحسن الأداء داخل & 11 \\
\hline متوسطة & $\varepsilon$ & $\cdot, 70$ & $r, r v$ & للاى مدرستي فريقاً فعالاً للتحسين المستمر. & IT \\
\hline منوسطة & 0 & $\cdot, \lambda r$ & $r, r$ & للدى مدرستي قو ائم لتحديد احتياجات العاملين فيها. & 1. \\
\hline \multicolumn{2}{|c|}{ كبيرة } & $\cdot, \wedge 9$ & $r$, or & الدرجة الكلية لمجال الجودة & \\
\hline
\end{tabular}




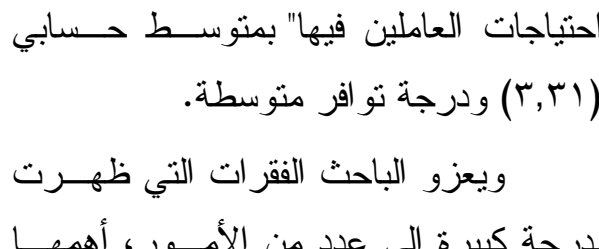

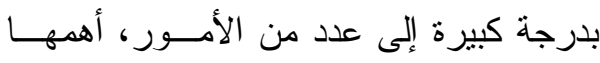

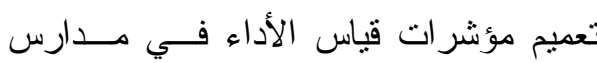

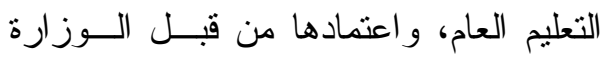

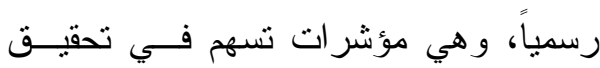

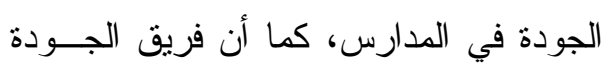

أصبح أحد الفرق التي يتوجب تشكيلها فـي

بداية كل عام في المدارس مما بـسـهم فـي لئي

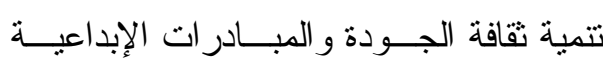

المرتبطة بها في المدارس. كما أن التوجهات

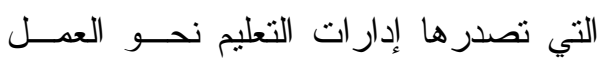

بصورة مستمرة على تطوير بيئة المدرســة،

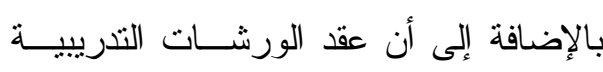

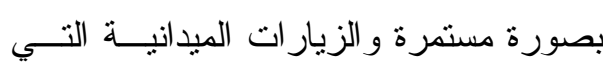

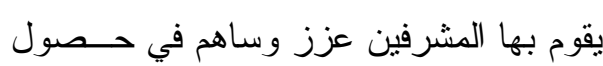

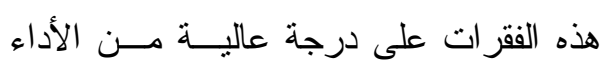

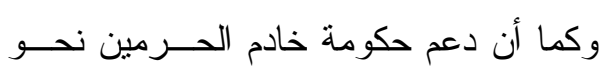

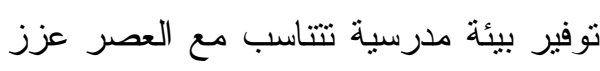
هذا الارتفاع في إيجاد بيئة مدرسية تضاهي مئي

$$
\text { المؤسسات العالمية. }
$$

أما ظهور بعض الفقــر ات بدرجـــة

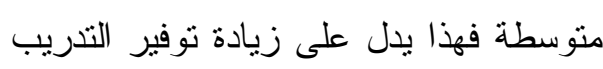

المناسب للمعلمين، بالإضافة إلى إيجاد بيئــة

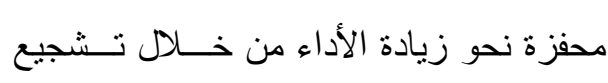

المعلمين المبدعين و إعطاء الحو افز سو اء
يثر الجـدول (9) إلــى أن تــوافر

مؤشرات مجال الجودة في مـــارس تعلــيم

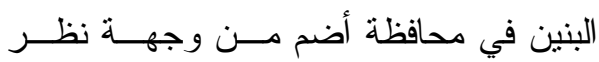

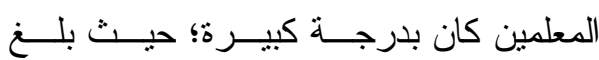

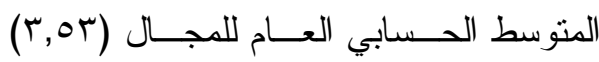

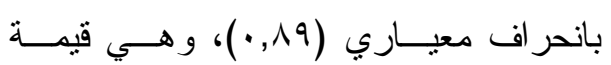

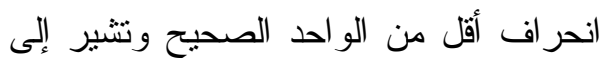

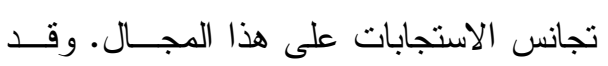

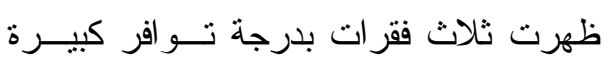

وفقرتان بدرجة متوسطة، بمتوسطات حسابية

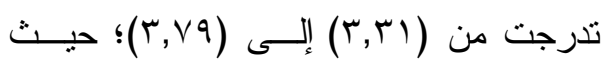

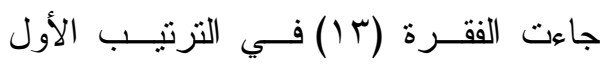

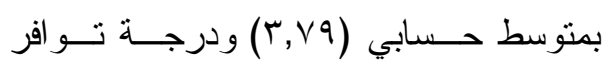

كبيرة، ونــصت علــى "تعتمــــ مدرســتي

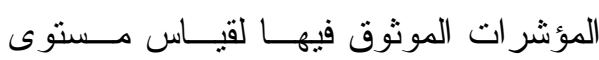

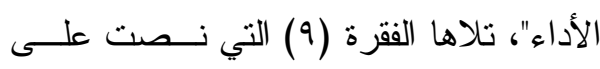

"تتمي مدرسني ثقافة الجودة لدى منـسـوبيها"

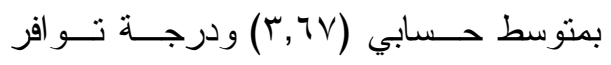
كبيرة، وفي الترتيب الثالث الفقــرة وفقــرة ودن (1) التي نصت علـى "تـضـع مدرســتي

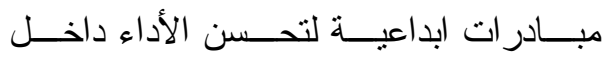

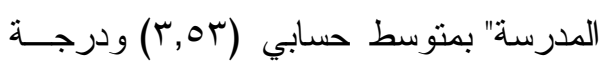

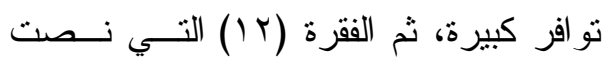

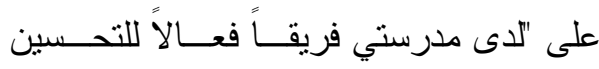

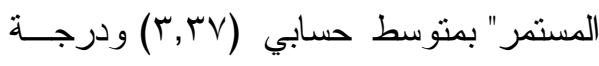

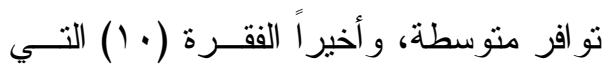

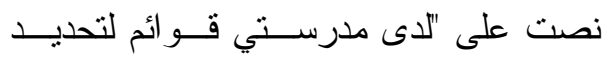




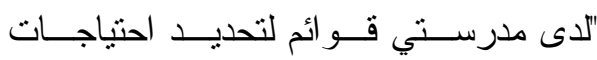

المادية أم المعنوية وإن ظهور فقرة

العاملين فيها" بدرجة منوسطة؛ فقد يرجع إلى مدي

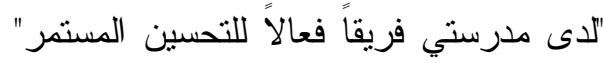

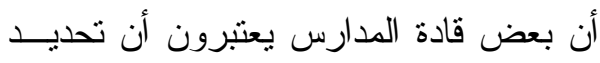

بدرجة منوسطة؛ فقد يرجع السبب إلـى أن فئ

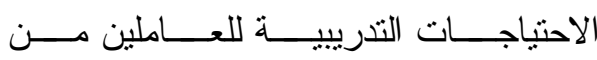

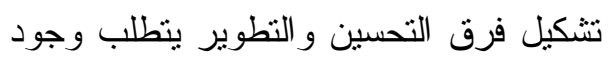
اختصاصات المشرفين التربوبين، ولا بد من

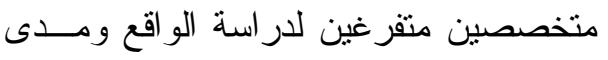
إيجاد البرامج التذريبية وفــق الاحتياجــات تحقيق الخطط لأهدافها ومعوقـات نتفيــذها،

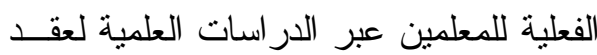

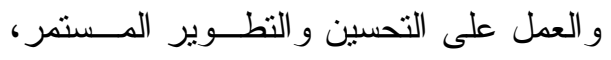

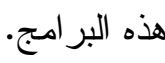

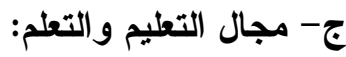

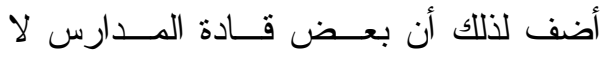
يعطون موضوع التحسين أهمية كبيرة أو لا لادن

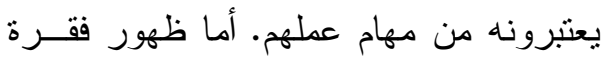

جدول (1.)

المتوسطات الحسابية والاحر افات المعيارية والارجة لمجال التعليم والتعلم مرتبة تنازلياً

\begin{tabular}{|c|c|c|c|c|c|}
\hline 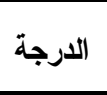 & 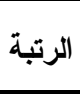 & الالمعراف & الحتوسطي & 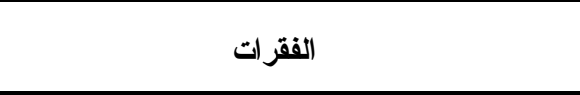 & b \\
\hline كبيرة & 1 & $\cdot, \wedge 0$ & r,人 & تعتمد مدرستي استر اتيجات تدريس متتو عه وحديثه. & $1 \leq$ \\
\hline كبيرة & r & $\cdot, \varepsilon r$ & r,Ar & تتوفر في فصول مدرستي التهوية و الإضـاءة الجيدة. & 11 \\
\hline 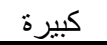 & r & $\cdot, 97$ & r,T4 & يُفعل معلمو مدرستي ملفات الانجاز كأداة للتقويم. & 17 \\
\hline 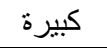 & $\varepsilon$ & $\cdot, 90$ & $r, \varepsilon 0$ & تشجع مدرستي المتعلمين على البحث و التجريب. & 10 \\
\hline متوسطة & 0 & 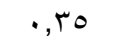 & $r, 19$ & فصول مدرستي مجهزة بالتقنيات التعليمية. & iv \\
\hline \multicolumn{2}{|c|}{ كبيرة } &., $0 Y$ & $r, 0 q$ & \multicolumn{2}{|l|}{ الدرجة الكلبة لمجال التعليج و التعلد } \\
\hline
\end{tabular}

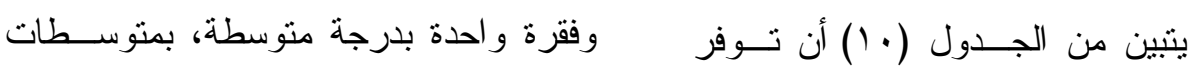

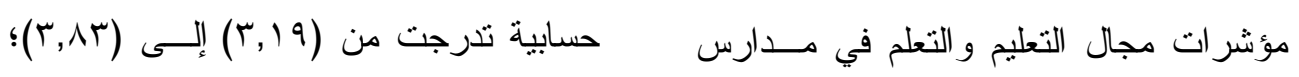

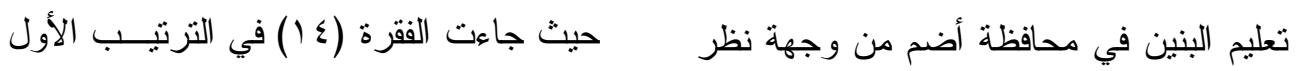

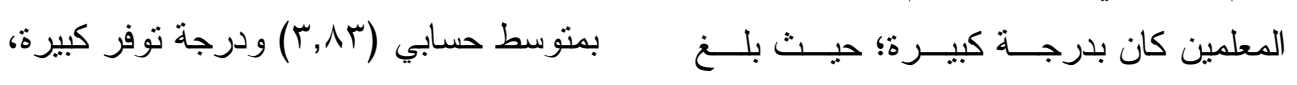

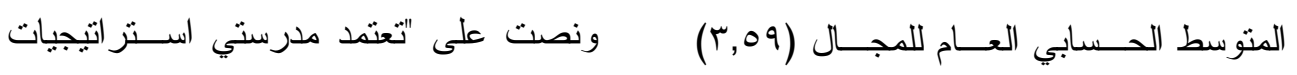

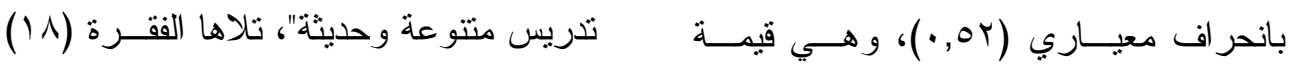

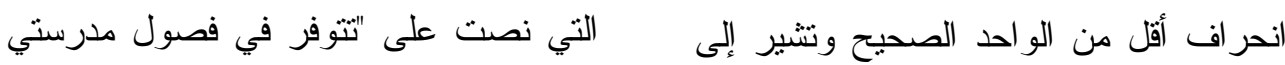

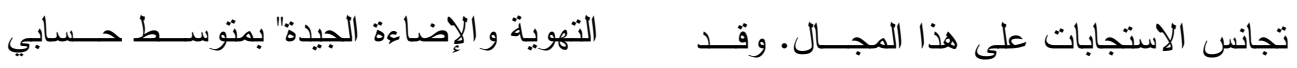

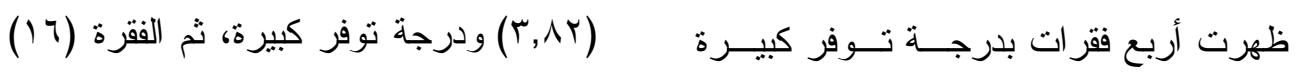


تدريس حديثة، أو تفعيـلـ طـــرق و أســاليب

بمتوسط حسابي (T,77) ودرجة نوفر كبيرة، التقويم الحديثة، كما أن المقررات الدراســية لتهية ونصت على "يُفعل معلمو مدرستي ملفــات المطورة تساعد على تبني و اعتماد مثل هذه الانجاز كأداة للتقويم"، وجاءت الفقــرة (IV) الاستر اتيجيات و الأساليب، إضافة إلى أنهــا

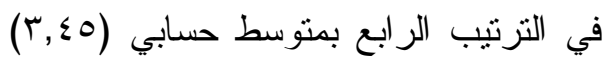

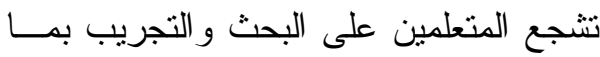
يحقق جودة عملية التعليم و التعلم.

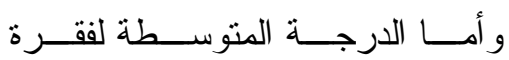
ودرجة نوفر كبيرة؛ حيث نصت على "تتجع مدرستي المتعلمين على البحث و التجريــبـ"، ودئ بينما ظهرت الفقرة (IV) في التزتيب الأخير "فصول مدرستي مجززة بالتقنيات التعليمية"،

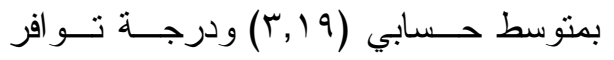

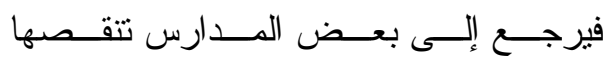

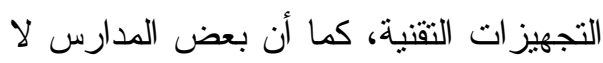
متوسطة، ونصت على "فـصول مدرســني مجززة بالتقنيات التعليمية".

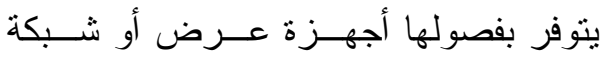
التعليم و التعلم إلى تبني معظم مدارس التعليم انترنت.

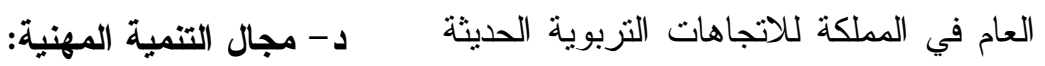
في التنريس، سواء في توظيف استر اتيجيات

جدول (1) (1)

المتوسطات الحسابية والاحر افات المعيارية والارجة لمجال التنمية المهنية مرتبة تنازلياً

\begin{tabular}{|c|c|c|c|c|c|}
\hline 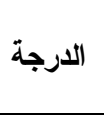 & 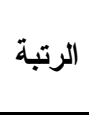 & 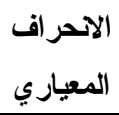 & المسابي & 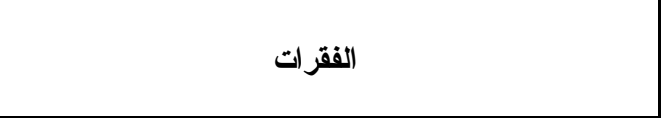 & p \\
\hline 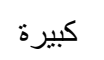 & 1 & $\cdot, r$ & $r, \uparrow$. & يمتلك العاملون بددرستي مهار ات التعلم الذاتي. & r. \\
\hline 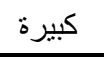 & r & $\cdot, \wedge \varepsilon$ & $r, 09$ & تعزز مدرستي مفهوم التتمية المهنية لدى العاملين. & 19 \\
\hline 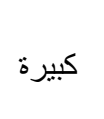 & $r$ & • & $r, 07$ & المتباديع مدرستي المعلمين على تنفيذ الحصص النموذجية & r \\
\hline 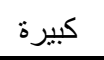 & $\varepsilon$ & $\cdot, \wedge 4$ & $r, 0$. & لتلبي مدرستي الحاجات التدرييية للعاملين. & rt \\
\hline متوسطة & o & V T & $r, r v$ & في حلقات نقانثية. & r) \\
\hline \multicolumn{2}{|c|}{ كبيرة } & $\cdot, 99$ & r,or & الدرجة الكلية لمجال التنمية المهنية & \\
\hline
\end{tabular}


الفقرة (Y) في النزتيب الأخيــر بمتوســـ حسابي (ץ,r,r) ودرجة توفر منوسطة، وقد نصت على "تــدعم مدرســتي اجتماعــات

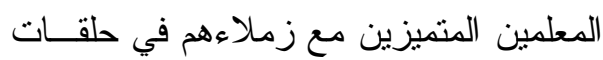
نقاثية".

وترجع الدرجة الكبيرة لمجال التتمية

المهنية إلــى أن مفهـوم التتميــة المهنيــة

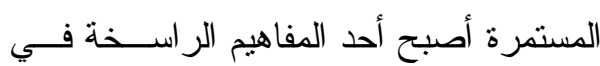

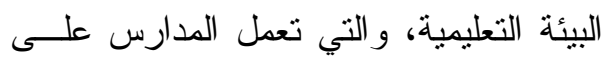
تعزيزه من خلال تدريب المعلمـين وتلبيـــة

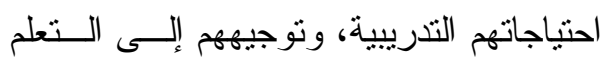
الذاتي كمصدر من مصادر التتمية المهنيــة، وتتجيعهم على اكتساب الخبرات و المهار ات

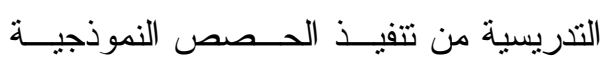
المتبادلة.

و أما الدرجة المتوسطة لفقرة "تــدعم مدرستي اجتماعات المعلمين المتميزين مــع

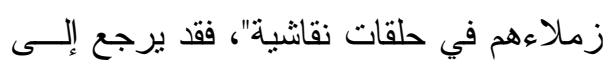

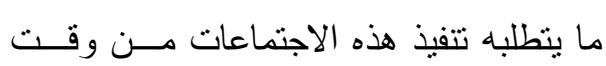
وتتظيم وخبرة في إدارتها، إضافة إلى تحديد

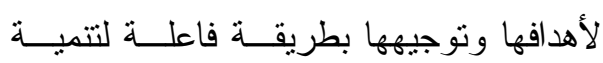

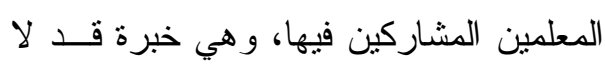
تتوفر لدى بعض قيادات المدارس. هـ- مجال المدرسة الرقمية:
يتضح من الجــدول (1) أن تـــوفر

مؤشرات مجال التتمية المهنية في مـــدارس تعليم البنين في محافظة أضم من وجهة نظر لنّا

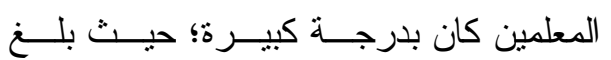

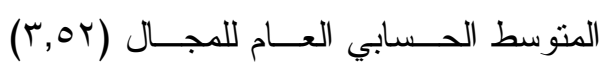

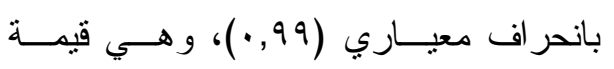

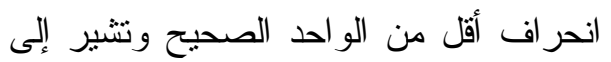

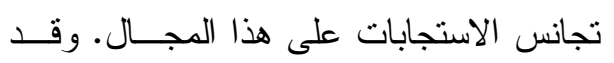

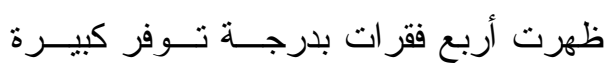

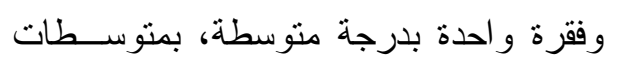

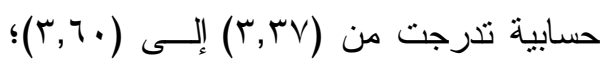

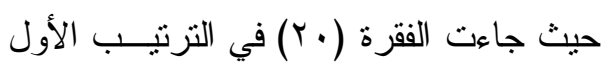

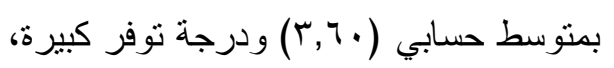

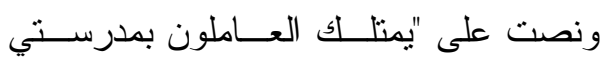

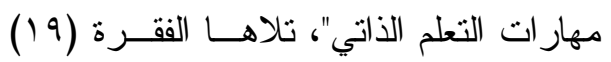

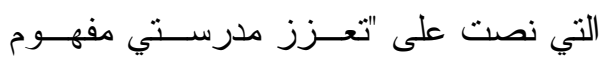
التنمية المهنية لدى العاملين" بمتوسط حسابي (r,09) ودرجة نوفر كبيرة، وظهرت الفقرة

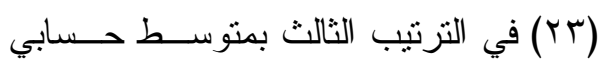

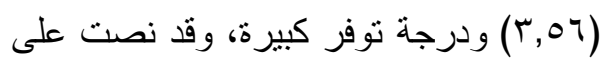

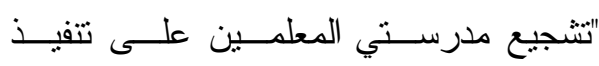

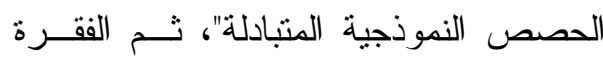

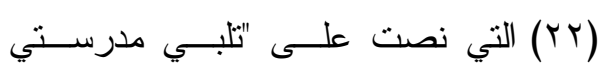
الحاجات التذريبية للعاملين" بمنوسط حسابي لابي

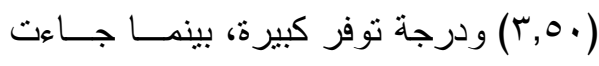




\section{جدول (r I )}

المتوسطات الحسابية والاحمر افات المعيارية والارجة لمجال المدرسة الرقمية مرتبة تنازلياً

\begin{tabular}{|c|c|c|c|c|c|}
\hline 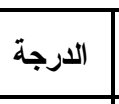 & الرتبة & المعياري & الحسابي & 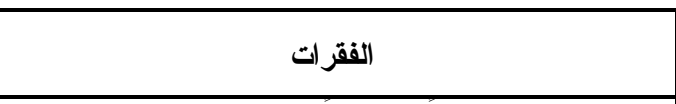 & p \\
\hline كبيرة & 1 & $\cdot, \wedge \varepsilon$ & $r, 01$ & تنتلك مدرستى موقعاً إلكترونيا. & $r \varepsilon$ \\
\hline كبيرة & r & $\cdot$, vo & $r, \varepsilon 1$ & 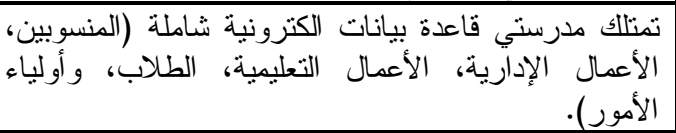 & rq \\
\hline | منوسطة & $r$ & $\cdot, \mathrm{V} r$ & $r, r 4$ & تو عي مدرستي منسوبيها بأهمية التعلم الإلكتروني. & rA \\
\hline | امتوسطة & $\varepsilon$ & $\cdot, \wedge 9$ & $r, r$. & تتو اصل مدرستي مع المجتمع المحلي إلكترونيا. & rq \\
\hline | متوسطة & o &., 971 & $r, r_{q}$ & بيئة التعلم في مدرسنى مجهزة بالثقنبات التعليمية الحديثة. & To \\
\hline | متوسطة & 7 & $\cdot, 7 \Lambda$ & $r, r q$ & تفعل مدرستى مركز مصادر التعلم إلكترونيا. & $T V$ \\
\hline \multicolumn{2}{|c|}{ متوسطة } & $\cdot, \mathrm{V} r$ & $r, \mu_{0}$ & الدرجة الكلية لمجال المدرسة الرقية & \\
\hline
\end{tabular}

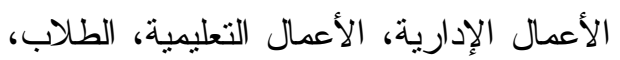

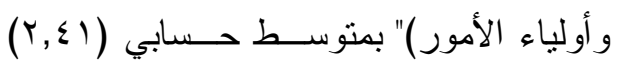

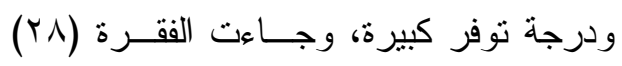

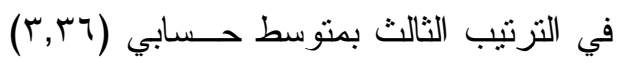

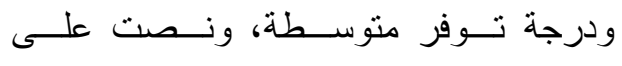

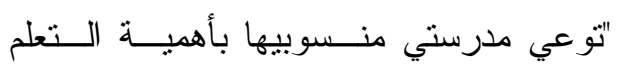

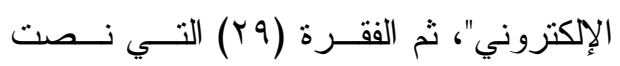

على "تتو اصل مدرستي مع المجتمع المحلــي لمي

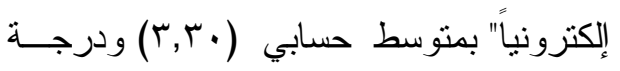

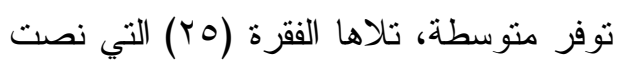

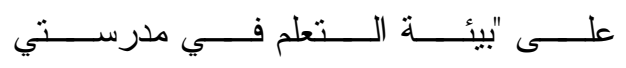

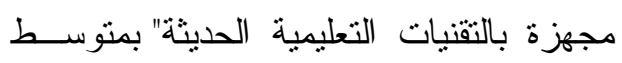

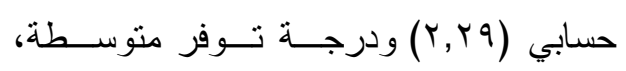

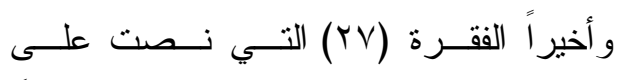

"تفعل مدرستي مركز مصادر التعلم إلكترونياً"

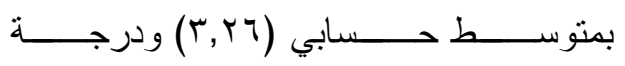

توفر متوسطة.

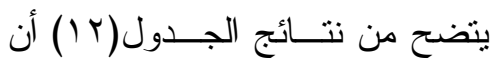

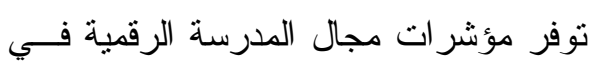

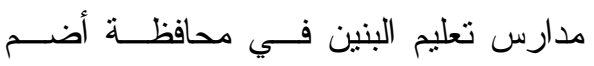

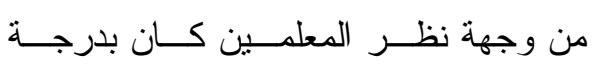

متوسطة؛ حيث بلغ المتوسط الحسابي العام

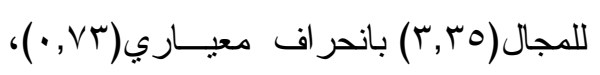
وهي قيمة انحر اف أقل من الواحد الصحيح

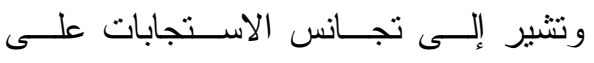

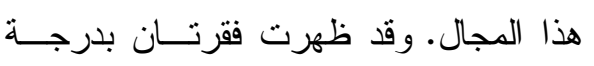
توفر كبيرة وأربع فقرات بدرجة منوسطة، وندان

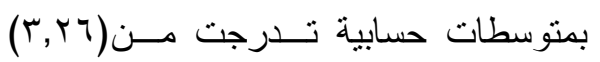

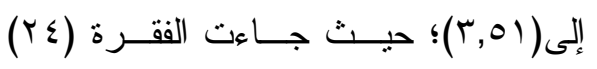
في التزتيب الأول بمتوسط حسابي (r,01)

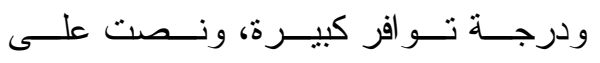

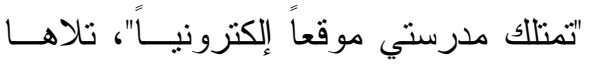

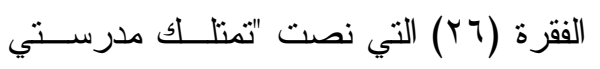
قاعدة بيانات الكترونية شاملة (المنـسـوبين، 
مواقع الكترونية ولكن خدماتها الفعلية قليلـــة، ولا تتعدى أن تكون مواقع تعريفية تتــنمن

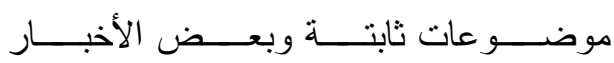

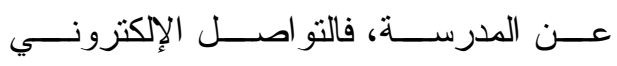

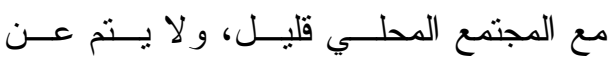
طريقه تفعيل بعض الخدمات التعليمية المهمة، كالتعلم الإلكتروني، أو مركز مصسادر التعلم، مما يقلل من قدرة المدارس على التحول نحو المدرسة الرقمية. د - مجال الشر اكة المجتمعية:
ويعزو الباحث الارجــة المتوســـة

لمجال المدرسة الرقمية إلى وجود قـصور في التحول بالمدارس نحو المدرسة الرقمية، و هو قصور يتمنل في عدة جوانب، بعضها يتعلق بسياسات وثقافة التحـــول الرقمــي، بعضها يتعلق بمقاومة التغييــر و العـــاملين في المــدارس، و الــبعض الآخــر يتعلــق بالإمكانات و التجهيز ات التي لاز الت تعــاني

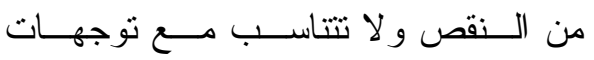

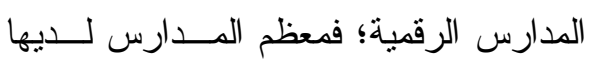

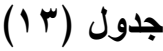

المتوسطات الحسابية والاحر افات المعيارية والارجة لمجال الشر اكة المجتمعية مرتبة تنازلياً

\begin{tabular}{|c|c|c|c|c|c|}
\hline الدرجة & الرتبة & الالمعر افياري & الحستوسط & 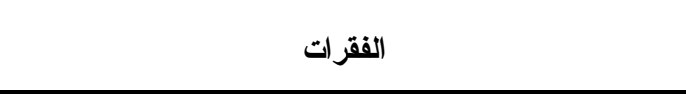 & b \\
\hline 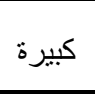 & 1 & $\cdot, \mathrm{V} \varepsilon$ & $r, q \wedge$ & تحرص مدرستي على أبناء العام الدراسي. & rt \\
\hline كبيرة - ان & r & $\cdot, \mathrm{V} \vee$ & 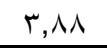 & تشكل مدرستي مجلس المدرسة بداية كل عام. & r. \\
\hline كبيرة - ان & r & $\cdot, 79$ & r,ی) & تتو اصل مدرستى مع أولياء الأمور في المناسبات المختلفة. & r \\
\hline 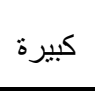 & $\varepsilon$ & $\cdot, \leqslant 9$ & r,0 & لزيارة المدرسة. مدرستي على دعوة قيادات المجتمع ورجال التعليم & r \\
\hline \multicolumn{2}{|c|}{ كبيرة } & $\cdot, \wedge$. & $r, \wedge 1$ & \multicolumn{2}{|l|}{ الارجة الكلية لمجال الشراكة المجتمعية } \\
\hline
\end{tabular}

ظهرت جميع الفقرات بدرجة نوفر كيــرة،

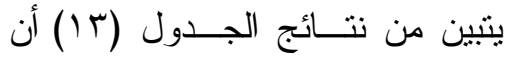

بمتوسطات حسابية تدرجت من (r,07) إلى

توفر مؤشرات مجال الثر اكة المجتمعية في

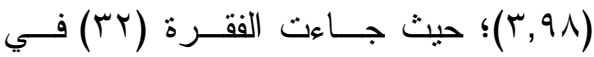

مدارس تعليم البنين في محافظة أضــم مــن

التزتيب الأول بمتوســط حسـابي (؟),

وجهة نظر المعلمين كان بدرجة كبيرة؛ حيث

ونصت على "تحرص مدرستي على إنـــعار

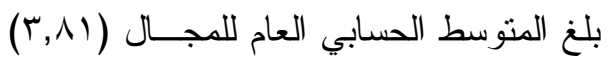

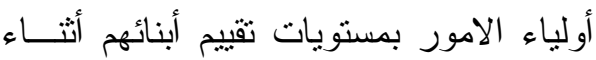

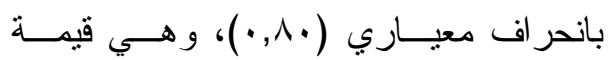

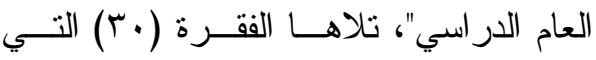

انحر اف أقل من الواحد الصحيح ونتشير إلى

نصت على "تثكل مدرستي مجلس المدرسة

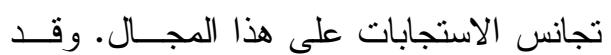




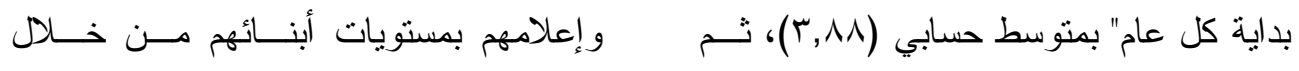

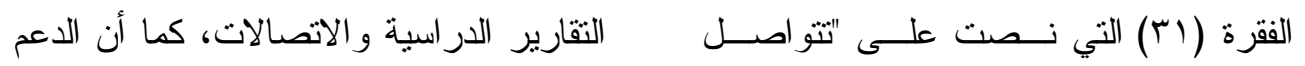

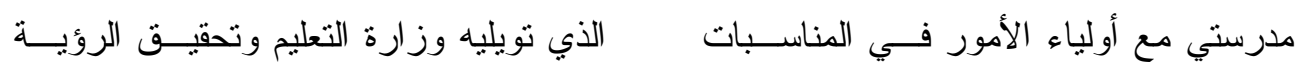

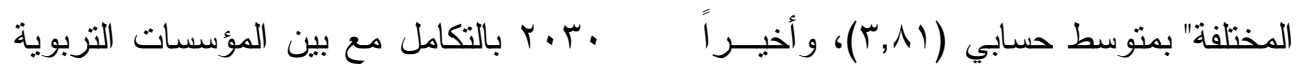

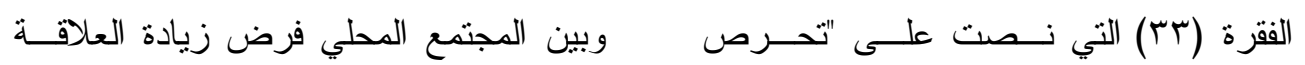

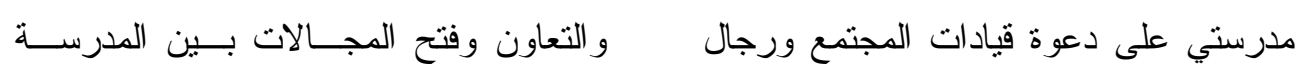

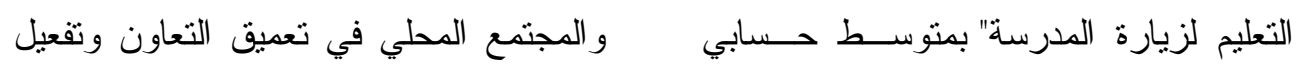

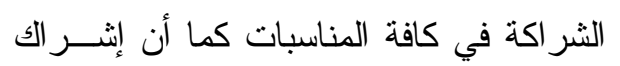

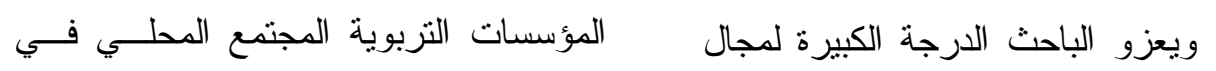

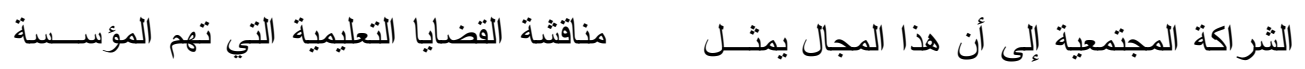

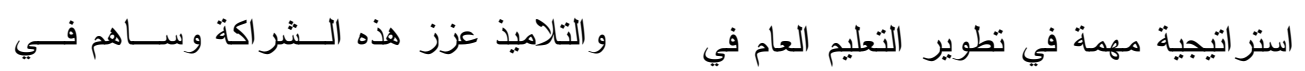

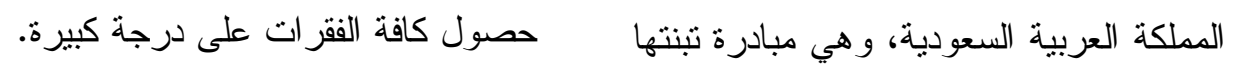

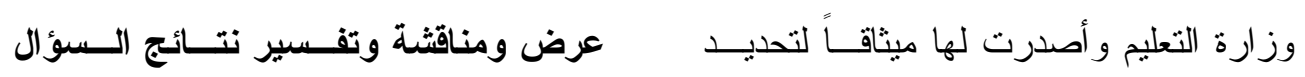

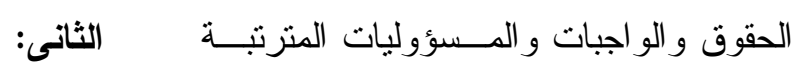

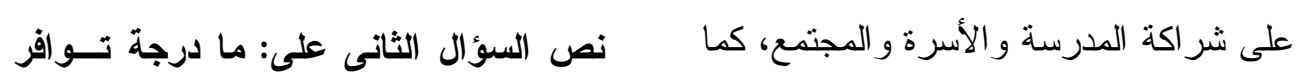

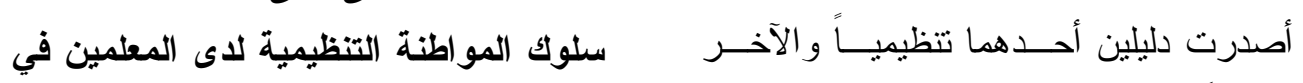

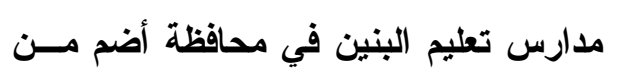
وجهة نظرهم؟ إجر ائياً من أجل تفعيل الــشر اكة المجتمعيـــة والاستفادة منها في تطوير العملية التعليمية،

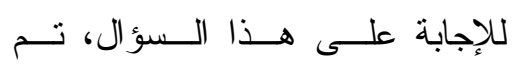
استخر اج المنوسطات الحسابية، و الانحر افات لاتجية

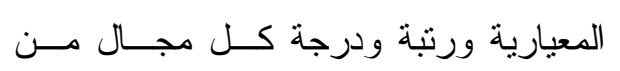
مجالات محور المواطنة التنظيمية، وترتيبها

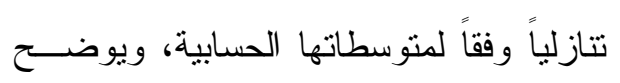

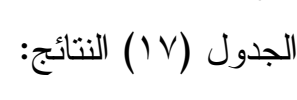

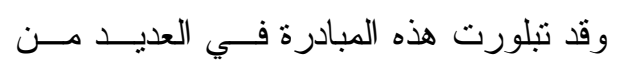

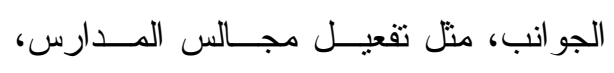
و التو اصل مع أولياء الأمور وقيادات المجنمع لئح

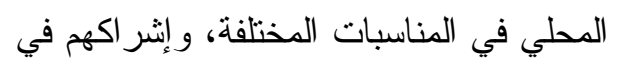
بعض الجوانب المتعلقة بالمدرسة وطلابهــا،

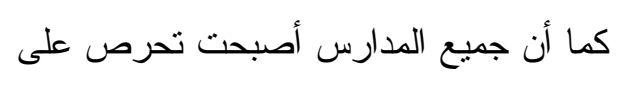

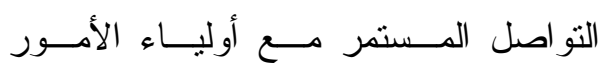




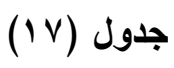

المتوسطات الحسابية والانحرافات المعيارية والدرجة لمجالات محور المواطنة التنظيمية مرتبة تتازلياً

\begin{tabular}{|c|c|c|c|c|c|}
\hline 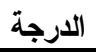 & 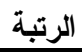 & الاتحر اف المعياري & المتوسط الحسابي & 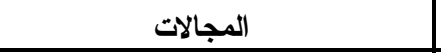 & \\
\hline كبيرة كبرة & 1 & $\cdot, \wedge$. & $\varepsilon, 17$ & [السلوك الحضاري & 0 \\
\hline كبيرة & r & $\cdot, \lambda V$ & $\varepsilon, \cdot \varepsilon$ & | لكياسة & r \\
\hline كبيرة & $r$ & •,AT & $\varepsilon, \cdot r$ & ل ل وعي الضمير & $\varepsilon$ \\
\hline كبيرة & $\varepsilon$ & • ג & $\varepsilon, \cdot 1$ & الروح الرياضية & 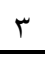 \\
\hline كبيرة & 0 & $\cdot, 99$ & $r, \varepsilon \wedge$ & | الإيثار & 1 \\
\hline \multicolumn{2}{|l|}{ ير } & $\cdot, \mathrm{VI}$ & $r, 9 \leq$ & للدرجة الكلية لمحور المو اطنة النتظيمية & \\
\hline
\end{tabular}

وقد ترجع الدرجة الكبيرة للمو اطنــة

التتظيمية لدى المعلمين إلى البيئة المدرســية

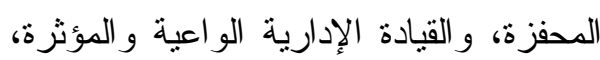

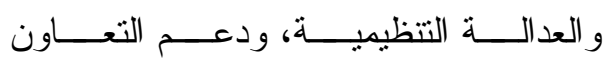
بــين المعلهـين ومسـشاركتهم فــي اتخــاذ

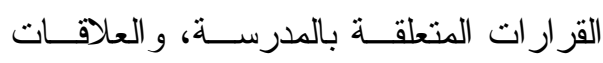

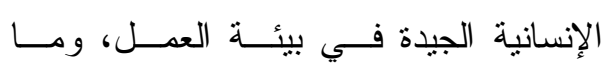
ينتج عن ذلك من رضا وظيفي يؤثر

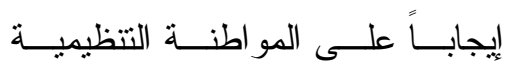

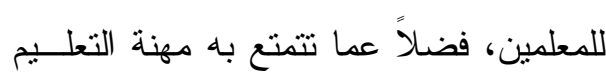

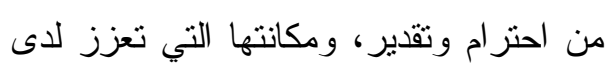
المعلم العديد من القيم والاتجاهات الايجابية،

بما في ذلك سلوك المواطنة التتظيمية. وتتقق هذه النتائج مع نتائج در اســات أهميت (Ahmet, 2016) ورحاب الوذيناني

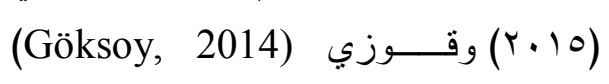

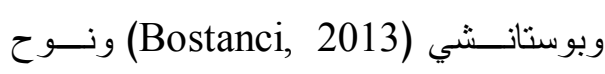

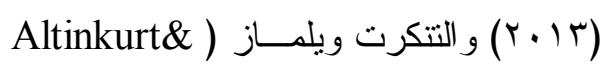

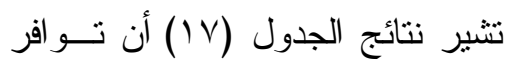

سلوك المو اطنة النتظيمية لدى المعلمين فـي لـي

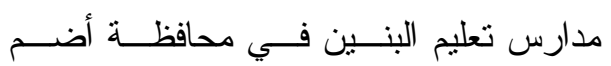

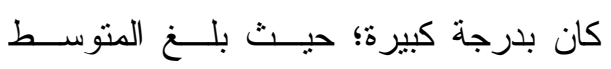

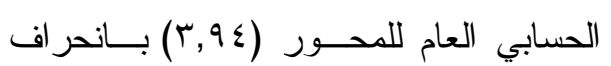
معياري (VT, • •)، و هي قيمة انحراف أقــلـل

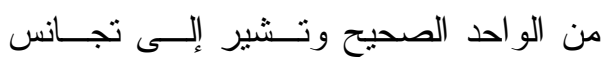

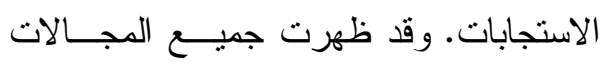

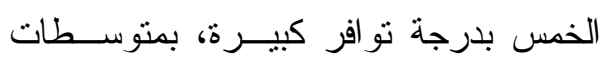

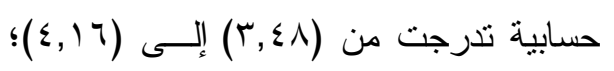

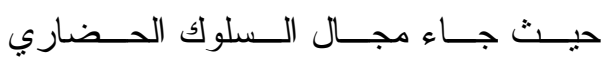

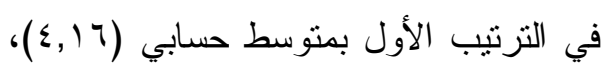
نلاه مجال الكباسة بمتوسط حسابي (ع •, ــ)،

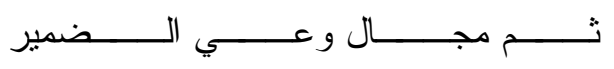

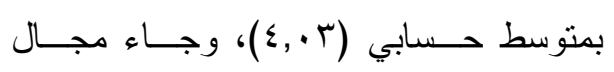
الروح الرياضية في الترتيب الر ابع بمتوسط وديط

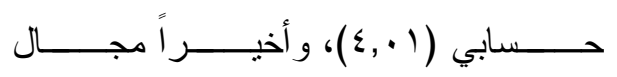

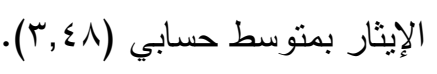




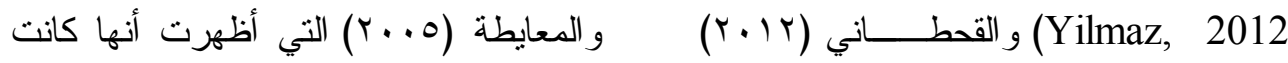

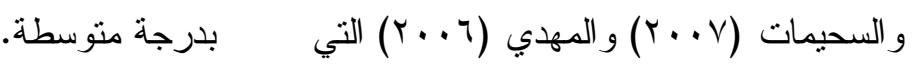

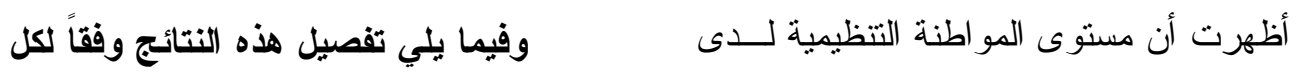

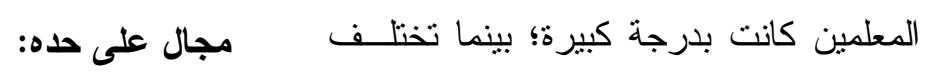

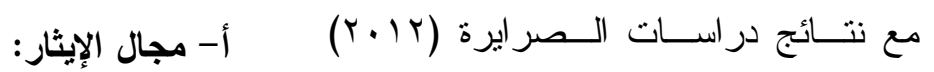

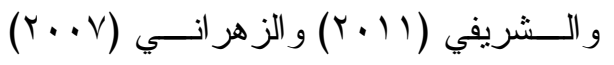

جدول (1)

المتوسطات الحسابية والاتحر افات المعيارية والدرجة لمجال الإيثار مرتبة تنازلياً

\begin{tabular}{|c|c|c|c|c|c|}
\hline الارجة & الرتبة & 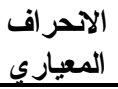 & الحستبي & الفقرات & p \\
\hline 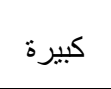 & 1 & $\cdot, 09$ & $\Gamma, \wedge \varepsilon$ & بالمعاون و الو اجبات مدرستي معيعة المعلمين الجــد لتعـريفهم & ro \\
\hline 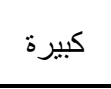 & $r$ & 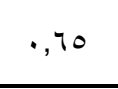 & $r, \uparrow \wedge$ & 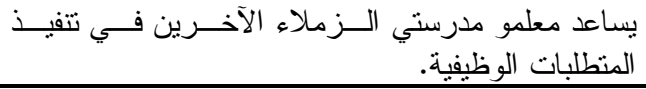 & $r \varepsilon$ \\
\hline متوسطة & $r$ & ת & $r, 9)$ & 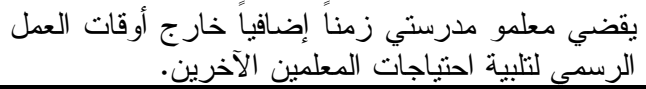 & דו \\
\hline \multicolumn{2}{|c|}{ كبيرة } & $\cdot, 99$ & $r, \leqslant \Lambda$ & الدرجة الكلية لمجال الإيثار & \\
\hline
\end{tabular}

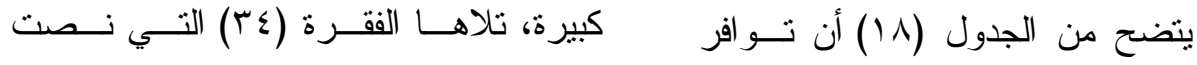

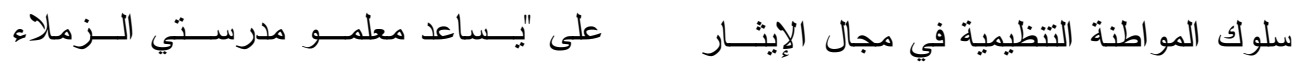

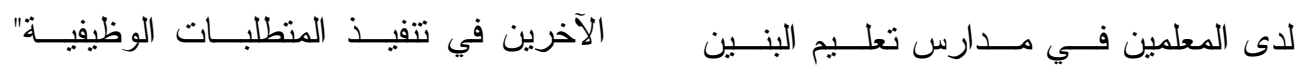

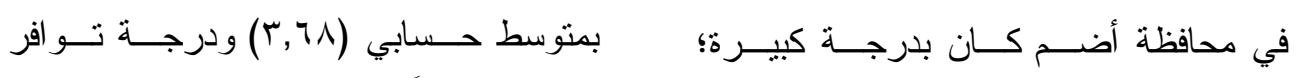

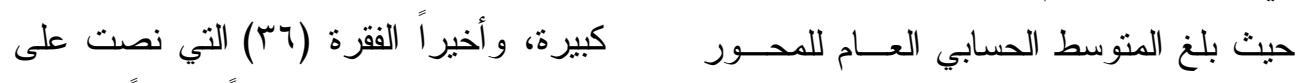

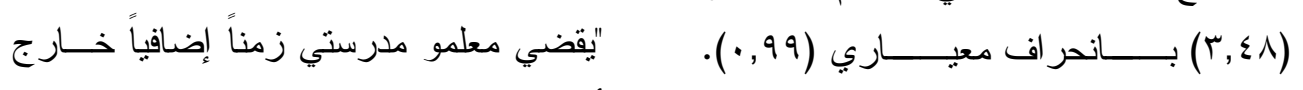

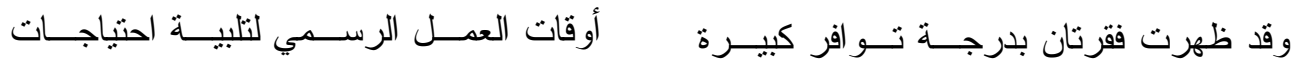

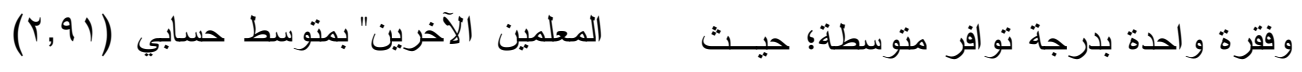

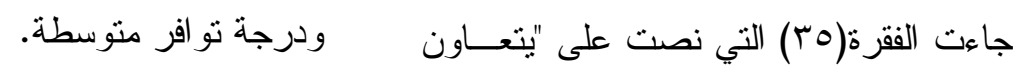

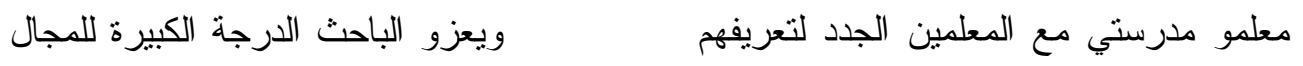

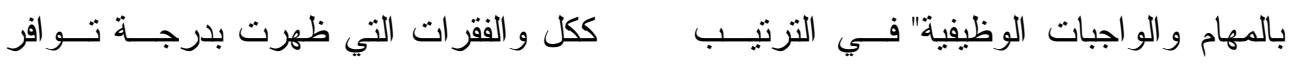

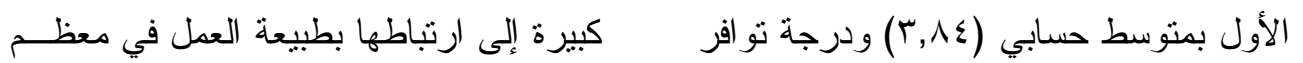


لبذل مزيــــــــن الوقــت خــارج أوقــات

المـــدارس التـــي بـــات تــشكيل فـــرق

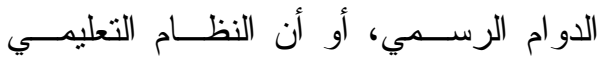

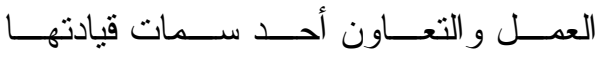

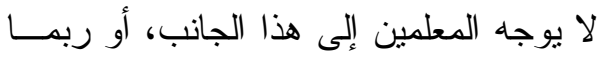
و أحد معايير تقييم عمل القيادات المدرســية، أن و اقع احتياجات المعلمين الفعلية لمـسـاعدة الفهية أما ظهور فقرة "يقـــي معلمــو مدرســتي زملائهم لا تتطلب مزيداً من الوقت خــارج

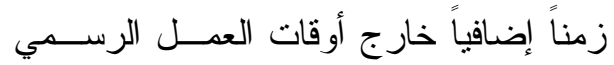
أوقات الدو ام.

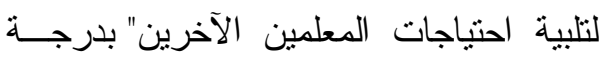

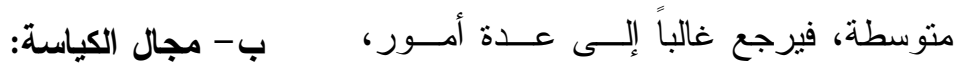

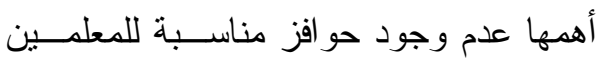

جدول (19)

المتوسطات الحسابية والاتحر افات المعيارية والارجة لمجال الكياسة مرتبة تنازلياً

\begin{tabular}{|c|c|c|c|c|c|}
\hline 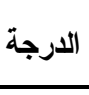 & 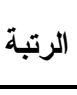 & الإنحر اف المعياري & المستوسطي & الفقر ات & p \\
\hline كبيرةٍ & 1 & $\cdot, 9 \wedge$ & $\varepsilon, r$. & للزمتلاء معلمو مدرستي الآخرين. & rq \\
\hline كبيرة & $r$ & $\cdot, 94$ & $\varepsilon, 11$ & يهتم معلمو مدرستي بحقوق الزملاء الوظيفية. & $\varepsilon$. \\
\hline كبيرة & $r$ & $\cdot, 7 \wedge$ & $\varepsilon, 10$ & العمل. معنب معلمو مدرستي إيذاء وجرح مشاعر زملائهم فــي & rᄉ \\
\hline كبيرة & $\varepsilon$ & $\cdot, 9 \wedge$ & $r, 9 \vee$ & الخاصة بالمدرسة. معلمو مدرستي على التشاور عند اتخاذ القــرارات & $\varepsilon 1$ \\
\hline كبيرة & 0 & $\cdot, 9 \leqslant$ & $r, r)$ & 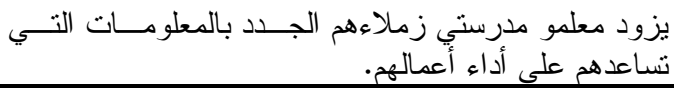 & rv \\
\hline \multicolumn{2}{|l|}{ ة } & $\cdot, \wedge \vee$ & $\varepsilon, \cdot \varepsilon$ & الدرجة الكلية لمجال الكياسة & \\
\hline
\end{tabular}

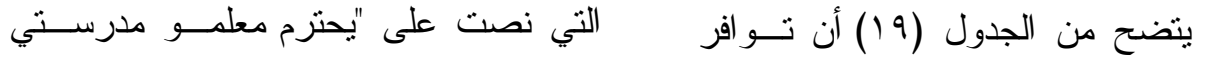

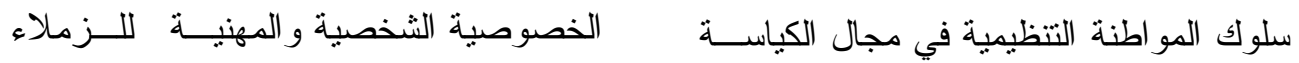

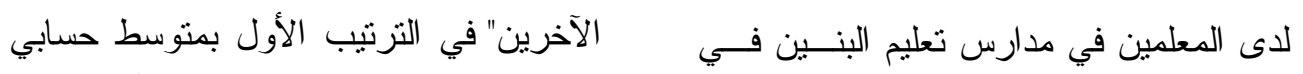

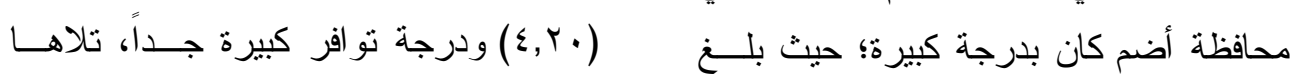

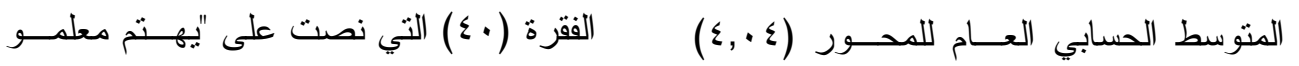

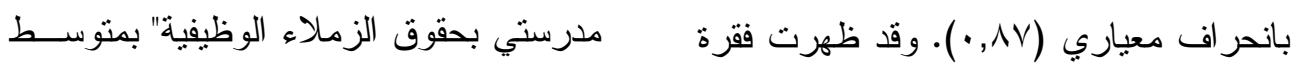

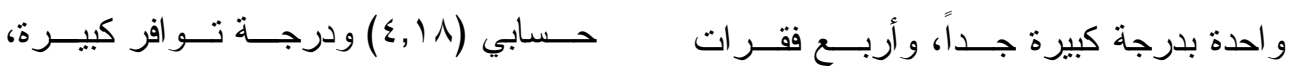

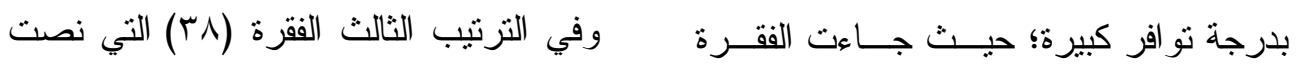
علــى "يتجنــب معلمــو مدرســتي إيــذاء 
قيادات المدارس على تفعيل هــذه العلاقــات

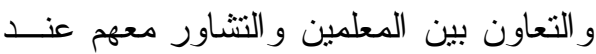

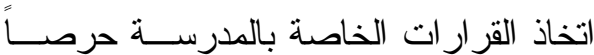
وتحسين أدائهـــا، بُــضـاف لــذلك مـسـتوى القيم التي تتسم بها مهنة التعلــيم وحــرص لترص المعلمون على التمسك بهذه القـيم، و التــي تظهر بصورة رئيسة في الاحتر ام المتبــادل

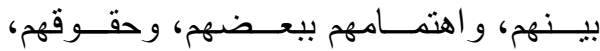
و الحرص علــى نفــع بعـــهم الــبعض، وتجنب الإساءة أو إيذاء المشاعر. ج- مجال الروح الرياضية: على نجاح خطط المدرسة وتحقيق أهـــدافها

وجرح مشاعر زمالائهم في العمل" بمتوســط

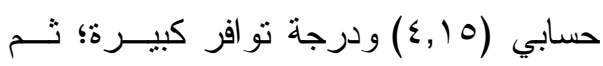
الفقرة (1) التي نصت على "يحرص معلمو مدرستي على التشناور عند اتخاذ القــرارات الخاصة بالمدرسة" بمتوسط حسابي (r,9V) ودرجة تو افر كبيرة، و أخيــراً الفقــرة (rv) التي نصت على "بــزود معلمــو مدرســتي زملاءهم الجدد بالمعلومات التي تـساعدهم على أداء أعمالهم" بمتوسط حسابي (Y,V ( ) ودرجة تو افر كبيرة.

ويعزو الباحث الدرجة الكبيرة لمجال

الكياسة إلى العلاقــات الإنــسانية الجيــدة، التي يؤكد عليها النظام التعليمي، وحــرص

جلول (•)

المتوسطات الحسابية والاتحر افات المعيارية والدرجة لمجال الروح الرياضية مرتبة تنازلياً

\begin{tabular}{|c|c|c|c|c|c|}
\hline 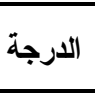 & 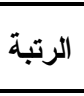 & المعياري & المتوسطي & الفقرات & p \\
\hline 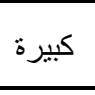 & 1 & $\cdot, 94$ & $\varepsilon, 1\}$ & 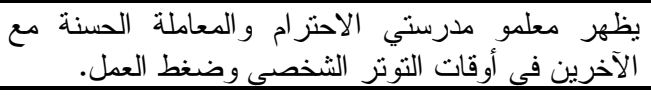 & $\varepsilon r$ \\
\hline 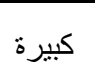 & $r$ & $\cdot, 97$ & $\varepsilon, \cdot r$ & الزماملاء الآخرين. مدرستي مع الإساءات الثخصية من قبل & $\varepsilon \varepsilon$ \\
\hline كبيرة - ان & $r$ & $\cdot, 9 \leq$ & $\varepsilon, \cdots$ & بو اجتلك معلمو مدرستي مهار ات معالجة المشكلات الــني & $\varepsilon r$ \\
\hline كبيرة & $\varepsilon$ & $\cdot, 70$ & $r, 9 \wedge$ & يعمل معلمو على تعزيز أداء العاملين في المدرسة. & $\leqslant 0$ \\
\hline 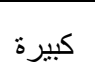 & 0 & $\cdot, 90$ & r, q & في اتخاذ القرار مدرستي المناسبة. & $\varepsilon 7$ \\
\hline \multicolumn{2}{|c|}{ كبيزة } & $\cdot, \wedge r$ & $\varepsilon,+1$ & الارجة الكلية لمجال الروح الرياضية & \\
\hline
\end{tabular}

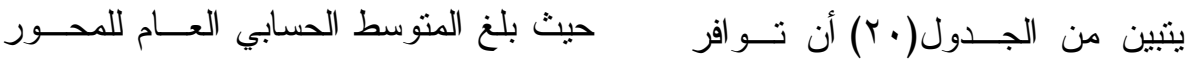

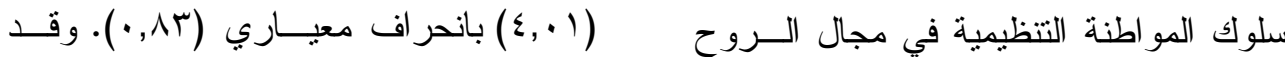

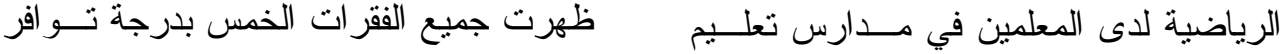
البنين في محافظة أضم كان بدرجة كبيـرة؛ كبيرة؛ حيث جاءت الفقرة (سء) في الترنيب 
لمساعدة الإدارة في اتخاذ القرارات المناسبة"

$$
\text { بمتو سط حسابي ( } 9 \text { ( } 9) .
$$

وقد يرجع السبب في الدرجة الكبيرة

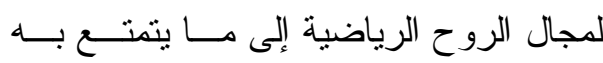

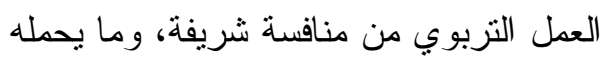

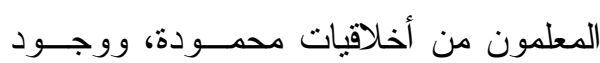

القيادات المدرسية المؤثرة، التي توفر البيئــة

المحفزة، وتسهم في تتمية مهار ات المعلمين

المختلفة، و إثثـــر اكهم فـــي الإدارة و واتخـــاذ

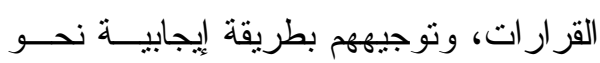

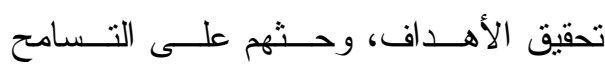

و الصبر ، و العمل التعاوني، و المشاركة فـي ولتي

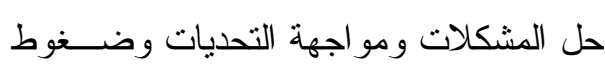

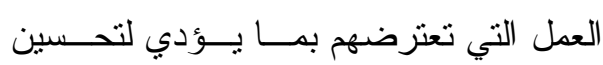

الأداء وتطويره.
الأول بمتوسط حسابي (Y, Y, ) ونصت على

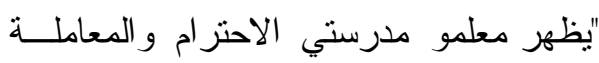

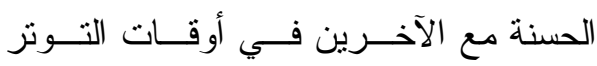

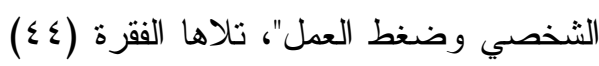
التي نصت على "يتسامح معلمو مدرستي مع

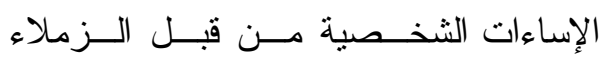

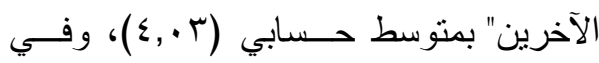

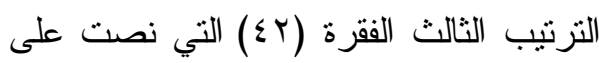
"يمنتلك معلمو مدرســتي مهــار ات معالجــة

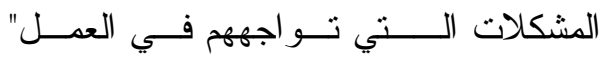

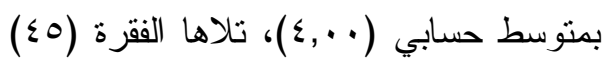
بمنوسط حسابي (؟,9^) ونصت على "يعمل معلمو مدرستي على تعزيز أداء العاملين في

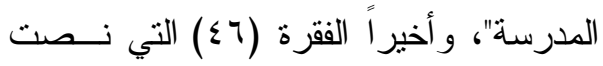
على "يمتلك معلمو مدرستي المهار ات الكافية

جدول (r)

المتوسطات الحسابية والاتحر افات المعيارية والدرجة لبُعد وعي الضمير مرتبة تنازلياً

\begin{tabular}{|c|c|c|c|c|c|}
\hline 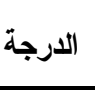 & 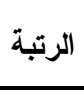 & 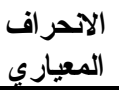 & المستوسط & الفقرات & b \\
\hline كبيرة & 1 & $\cdot, 9 \leq$ & $\varepsilon, 1 \wedge$ & يتقبد معلمو مدرستي بالأنظمة و التعليمات المدرسية الصادرة & $\leqslant \wedge$ \\
\hline 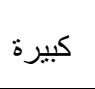 & r & $\cdot, 9 \vee$ & $\varepsilon, 1 \Gamma$ & التعلمية للطعلاب. مدرستي بالعدالة و الأمانة في توزيع الدرجات & 01 \\
\hline كبيرة & r & $\cdot, 94$ & $\varepsilon, \cdot \wedge$ & بلتزم معلمو مدرستي بالدو ام الرسمي. & $\leqslant V$ \\
\hline كبيرة & $\varepsilon$ & $\cdot, 9$. & r,^q & 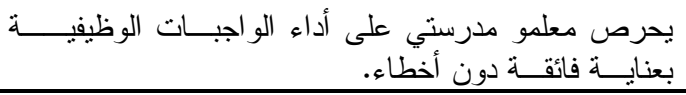 & $\leqslant 9$ \\
\hline كبيرة & 0 & $\cdot, 94$ & r,^० & العمل. مقي معلمو مدرستي معظم ساعات العمل في أداء و اجبات & o. \\
\hline \multicolumn{2}{|c|}{ كبيرة } & $\cdot, \wedge r$ & $\varepsilon,+r$ & الارجة الكلية لمجال وعي الضمير & \\
\hline
\end{tabular}




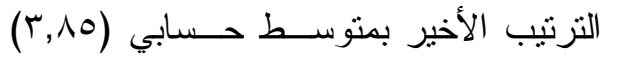

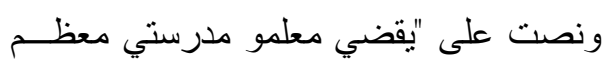
ساعات العمل في أداء واجبات العمل". ويعزو الباحث الدرجة الكبيرة لمجال

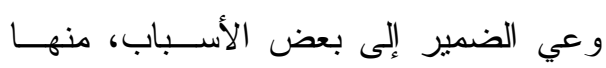

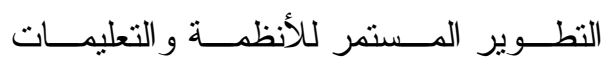

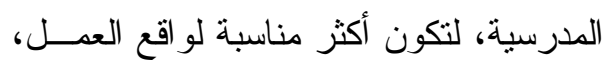

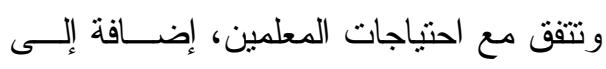

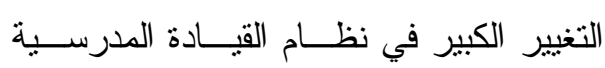

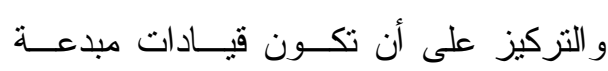

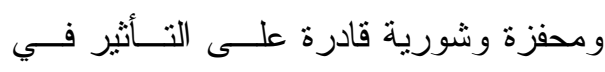

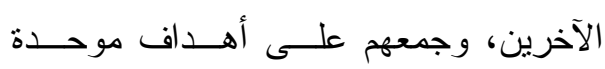

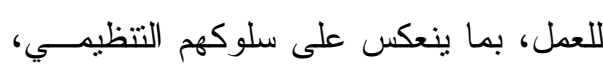
فيظهر في صورة التز ام بالأنظمة و التعليمات

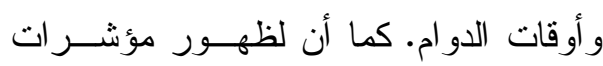
الأداء، وتطوير أنظمة تقييم المعلمين، و الحث

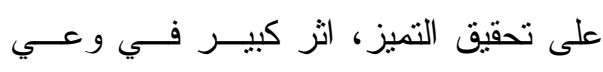
الضمير لدى المعلمين. هـ- مجال السلوك الحضاري:
تشير نتائج الجـدول (Y) إلـى أن

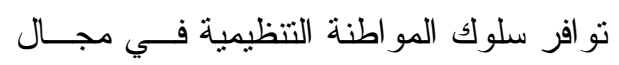
وعي الضمير لاى المعلمين في مدارس تعليم

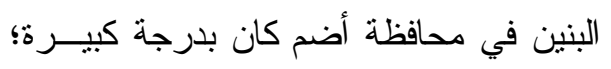

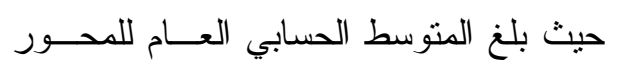

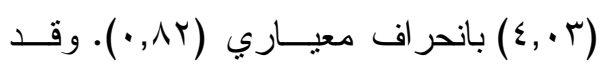

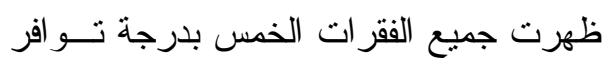
كبيرة؛ حيث جاءت الفقرة (^^) في النزتيب

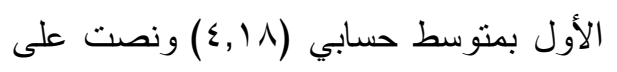

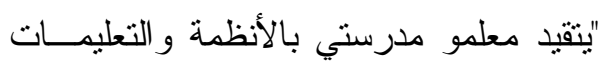

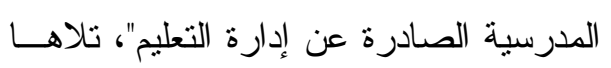
الفقرة (10) التي نصت على "يتعامل معلمو

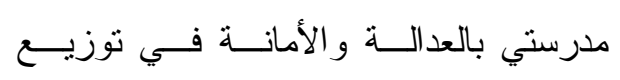
الدرجات العلمية للطلاب" بمنوسط حسـابي لعابي

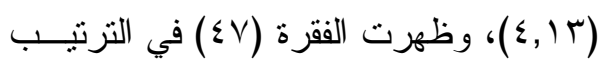

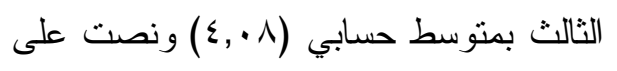

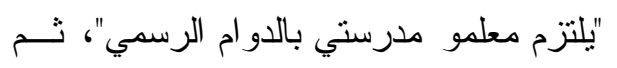

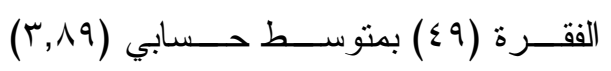

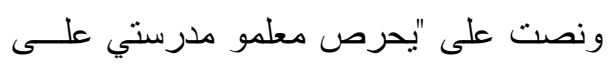

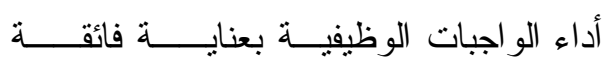

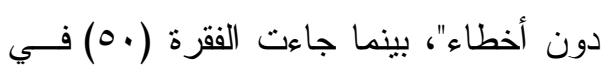




\section{جدول (r)}

المتوسطات الحسابية والاتحر افات المعيارية والارجة لمجال السلوك الحضاري مرتبة تنازلياً

\begin{tabular}{|c|c|c|c|c|c|}
\hline 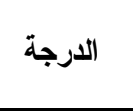 & الزتبة & 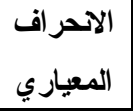 & العسابي & الفقرات & p \\
\hline 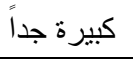 & 1 & $\cdot, \wedge \varepsilon$ & $\varepsilon, \varepsilon$. & يظهر معلمو مدرستي بالمظهر المناسب و الملائم لوظيفتهم. & or \\
\hline كبيرة & r & $\cdot, 9$ & $\varepsilon, 19$ & يدافع معلمو مدرستي عن سمعة المدرسة و أهدافها. & or \\
\hline كبيرة & r & $\cdot, 91$ & $\varepsilon, 10$ & 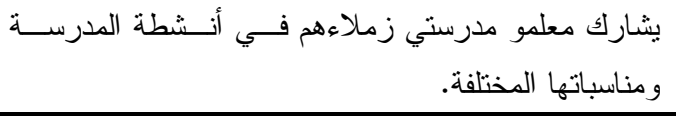 & $0 \leqslant$ \\
\hline كبيرة & $\varepsilon$ & $\cdot, 99$ & $r, q$. & يقدم معلمو مدرستي العديد من المقترحات لنطوير العمل. & 00 \\
\hline \multicolumn{2}{|c|}{ كبيرة } & $\cdot, \wedge$ & $\{, 19$ & الارجة الكلية لمجال السلوك الحضاري & \\
\hline
\end{tabular}

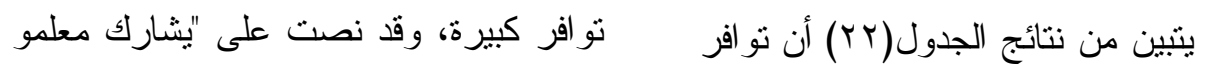

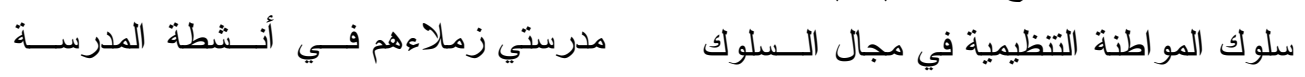

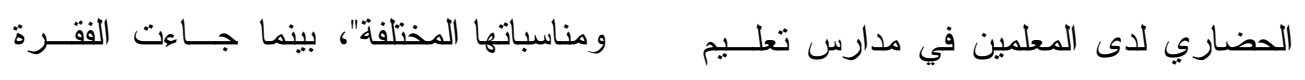

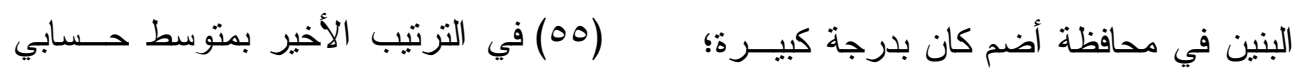

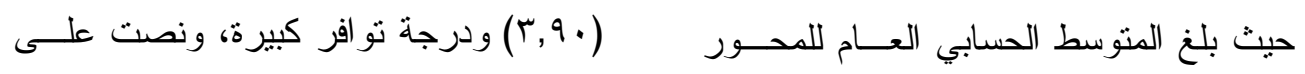

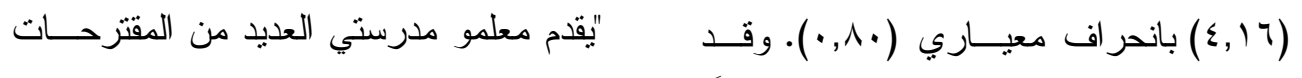
ظهرت فقرة واحدة بدرجة تو افر كبيرة جداً، ل لنطوير العمل".

وقد ترجع الدرجة الكبيــرة لمجـــال

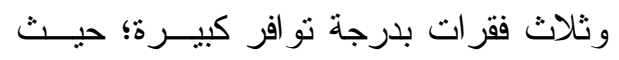

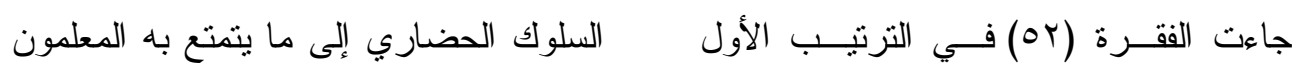

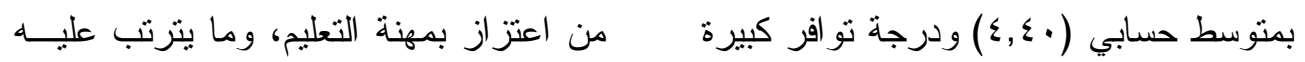

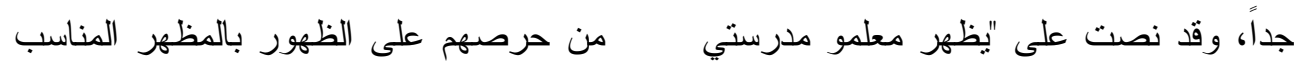

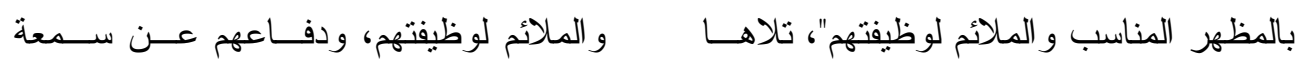

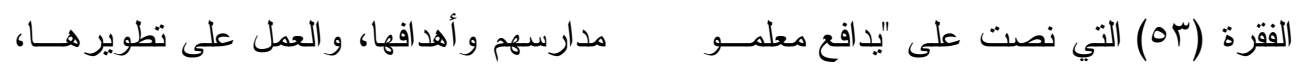

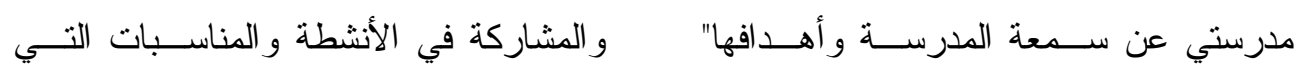

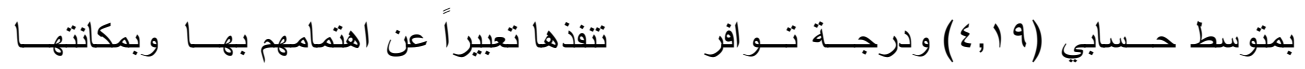

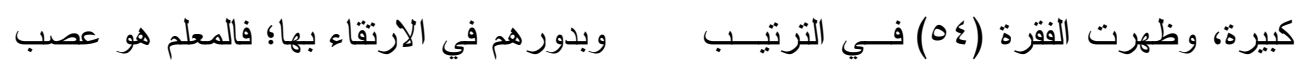

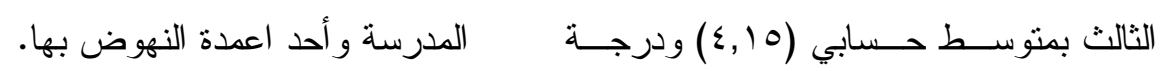


عرض ومناقثتة وتفسير نتائج السؤال المعلمين في مدارس تعـيم البنـين فـي محافظة أضر؟ في مبر

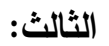
لإلإبابة على هذا السؤال تم حسباب نص السؤال الثالث على: هل توجد علاقـــة

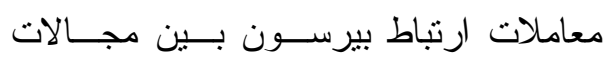

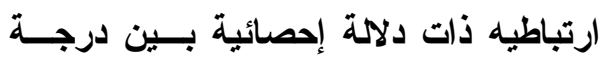

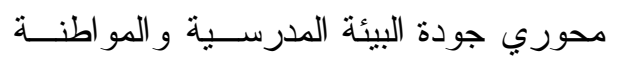

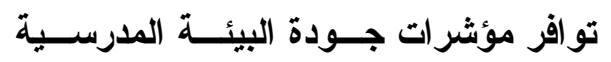

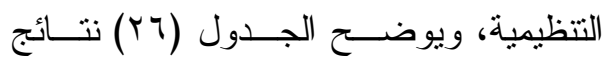

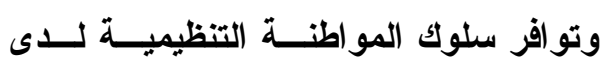
الارتباط:

جدول (جr) العلاقة بين درجة تو افر مؤشرات جودة البيئة المدرسية

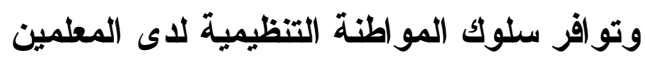

\begin{tabular}{|c|c|c|c|c|c|c|}
\hline التنظيمية & الحضاري & الضمير & الرياضية & الكياسة & الإيثار & المجالات \\
\hline$* \cdot, T \times 1$ & $* \cdot, 0 \vee \wedge$ & $* ., 0 \times 1$ & $* \cdot, T \cdot V$ & $\because ., 001$ & $* \cdot, 74 Y$ & التمبز القيادي \\
\hline$* \cdot, v \cdot 1$ & $* \cdot, 7,0$ & $* \cdot, 7,1$ & $* \cdot, T \leqslant Y$ & $* ., 0 \vee T$ & $* \cdot, 7 \wedge \varepsilon$ & الجودة \\
\hline$*, V Y \wedge \wedge$ & 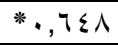 & $*, 70$. & $*,, T \leqslant V$ & $* ., O \Lambda Y$ & $*, V, Y$ & التعليح و التعلم \\
\hline$*, \vee \vee 9 \wedge$ & ${ }^{*} \cdot, 7 \Lambda \varepsilon$ & **.,79Y & $*_{*}^{*}, V \backslash Y$ & $* \cdot, 7 \wedge \wedge$ & $*_{\bullet}, V \backslash\{$ & التنمية المهنية \\
\hline **, $74 \leqslant$ & $* 0,0 \leqslant 0$ & 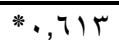 & $* ., 019$ & $* \cdot, 0 \leqslant 0$ & $* ., 701$ & المدرسة الرقمية \\
\hline **, $, \wedge, 7$ & $* \cdot, 799$ & **,VIY & $\left.*_{*}^{*}, V\right) \leqslant$ & **,,$V Y)$ & $*_{0}, V \Gamma \varepsilon$ & الثر اكة المجتمعية \\
\hline$\because,, \wedge \mid 7$ & $* \cdot, V, Y$ & $*,, V \backslash \wedge$ & $*, V \Gamma)$ & $\because, 701$ & $*, \vee \vee \wedge \varepsilon$ & جودة البيئة المدرسية \\
\hline
\end{tabular}

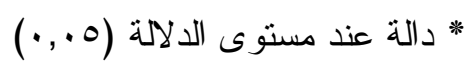

على المجالات الفرعية، فكلما زادت درجــة أي مجال من مجالات جودة البيئة المدرسـية زلية

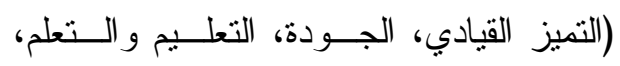

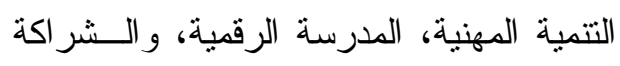
المجتمعية) زاد مستوى المواطنة التتظيميــة

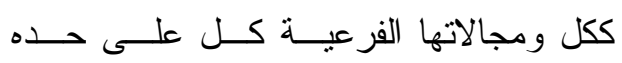

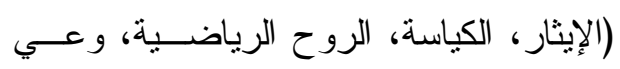
الضمير ، و السلوك الحضاري).

ويعزو الباحث هذه العلاقة الإيجابيـــة إلى أن تو افر مؤشرات جودة البيئة المدرسية الإنابة يؤدي إلى علاقات إنسانية ومهنية جيدة فـي لئي
يتبين من نتائج الجدول (Tr) وجود

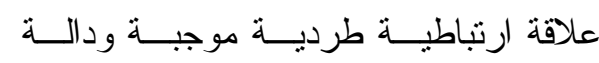

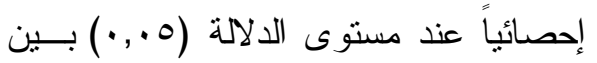
درجة تو افر مؤشرات جودة البيئة المدرسية

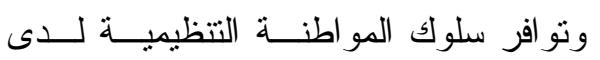

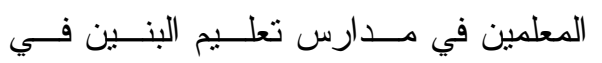
محافظة أضم، سواء في الدرجة الكلية لكل فل فيل

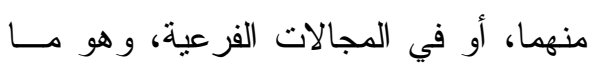
يعني أنه كلما زادت درجة نو افر مؤشرات جودة البيئة المدرسية زاد مستوى المواطنة

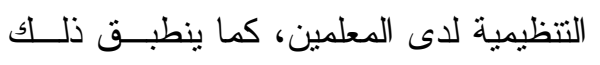


الترتيب، بينما ظهـر مجـــال المدرســة الرقمية بدرجة منوسطة. - يتوفر سلوك المواطنة التنظيميــة لــدى المعلمين في مدارس تعليم البنـين فــي محافظة أضم من وجهة نظر هم بدرجـة ملة عامة كبيرة، وكذللك في جميع المجــالات الخمس التي ظهرت بدرجة كبيرة علـى الترنيب التــالي: الـسلوك الحـــاري،

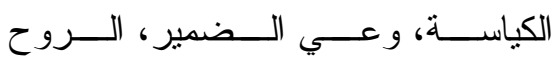

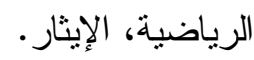

- توجد علاقة ارتباطية طرديـــة موجبــة

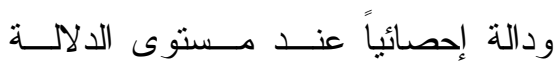
(0. ( • ) بين درجة توفر مؤشرات جودة البيئة المدرسية وتوفر سلوك المواطنــة التتظيمية لدى المعلمين في مدارس تعليم البنين في محافظة أضـــم، ســـواء فــي الدرجة الكليــة لكــل منهمـــا، أو فــي المجالات الفرعية، وهو ما يعني أنه كلما زادت درجة توفر مؤشر ات جودة البيئـة المدرسية زاد مستوى المو اطنة التتظيمية لاى المعلمين. ثاتياً: التوصياث:

في ضوء النتائج التي توصــــت لهــا الدر اسة؛ فإنه يمكــن الخــروج بالتوصــيات التالية:
بيئة العمل، كما بوفر بيئـة مناسـبـة لأداء أفضل، ويسهم في تحقيق منافسة شريفة بين المعلمين، وزيادة مستوى التفاهم و التعــاون بين بعضهم البعض، وبينهم وبــين القـادة؛

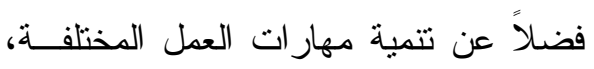
ومشاركة المعلمين في قيادة المدرسة واتخاذ القرار ات المتعلقة بالعمــل، الأمــر الــذي

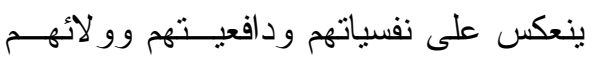
للمدرسة ونظامها، و التــز امهم الــــــيفي، وبالتالي ينمــو لــيهم الـشتور بالإيثتـار

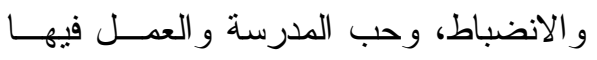
و الثعور بالمـسؤولية تجاههــا، وتجنــبـ الخلافات و الصر اعات التي تؤثز على جودة هذه البيئة، وبالتالي الاهتمام بها و المحافظة عليها، و التعاون في تحقيق أهدافها، و السعي المستمر لتطوير ها.

ملخص نتائج الدراسة والتوصيات والمقترحات أولاً: الاستتناجات: توصلت الدر اسة للنتائج التالية: - توفر مؤشرات جودة البيئة المدرســية في مدارس تعليم البنين فـــي محافظـــة أضم من وجهة نظر المعلمــين كــان بدرجة عامة كبيـرة؛ حيـــث ظهــرت مجالات (الثر اكة المجتمعيـــة، التمبــز القيــادي، التعلـــيم و الــتعلم، الجـــودة، و التتمية المهنية) بدرجة كبيــرة علـى 
- تجهيــز فــصول المـــارس بــالأجهزة

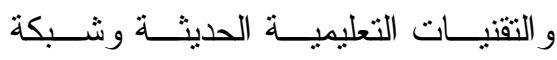

الانترنت، و التي تضمن استفادة الطـــلاب

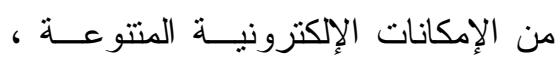

وتدعم التعلم الإلكتروني في الإلــــارس،

وتحولها إلى مدارس رقمية.

- الاستفادة من بر امج وتقنيــات التو اصـــل

الإلكتروني في إنثاء شر اكات اجتماعيـــة

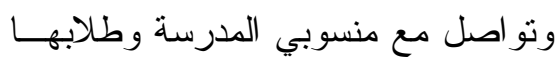

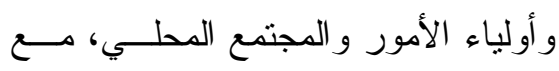

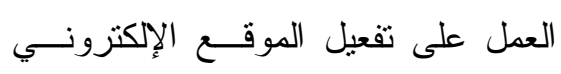

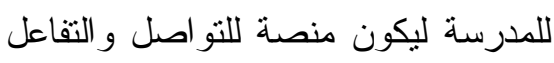

$$
\text { مع المجتمع المحلي. }
$$

- الاهتمام بتوفير بيئة مدرسية تتسم بالجودة

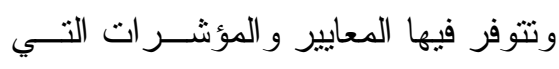

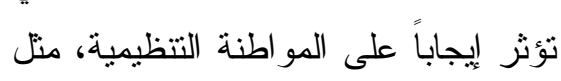
التميز القيادي، وجــودة عمليــة التعلــيم

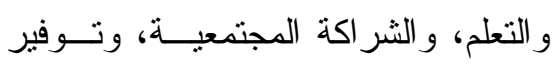

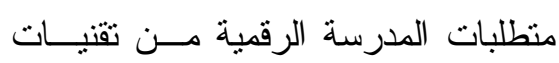
وبرمجيات، و التتمية المهنيــة المـستصرة للمعلمين بما يحقق طموحاتهم الوظيفيــة

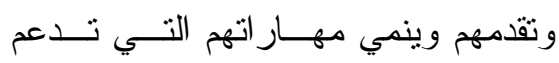
رضاهم و التز امهم الوظيفي. ثالثاً: المقترحات: ت رصاه و

يقترح الباحث إجراء بعض الدراسات التي تثري موضوع الدراسة، ومن أهمها:
- بذل مزيد من الجهود لتحقيــق جــودة البيئة المدرسية في مدارس التعليم العام بمحافظة أضم، ودعم ونظوير الجوانب الني أظهرتها الدراسة بدرجة متوسطة، ودة ونطوير وذلك من خلال ما يلي: - تخصيص فريــق تطــوير وتحـسين متخصص ومتقرغ لكل مدرسة، أو لكل فئل فئ مجمو عة مدارس و اقعة فــي نطاقـات

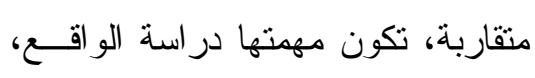

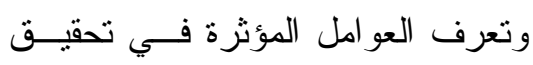

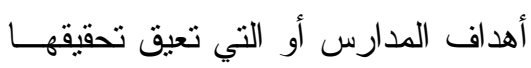

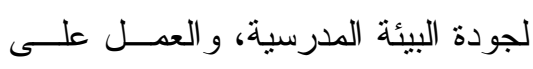
الحد من هذه العو امل وابتكار أســاليب و أفكار لتحسين وتطوير الأداء وتحقيق

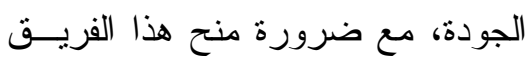

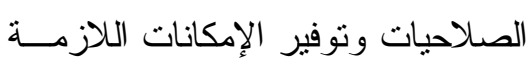

$$
\text { لنجاح دوره. }
$$

- تدريب قادة المدارس علــى اســتخدام

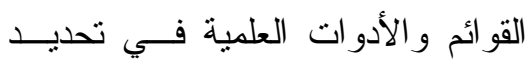
الاحتياجات التدريبية للمعلمين و العاملين

$$
\text { في المدارس. }
$$

- توطين التدريب في المدارس، بما يدعم تتويع أساليب التتمية المهنية، وتـــوفير الوقت و الجهد، وتدريب المعلمين وفقــاً

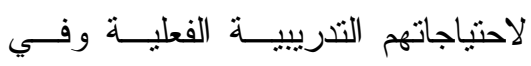
المكان. 
التنظيميــة فــي مر اكــز الــــز ارات الحكومية في الأردن، مجلة الجامعـة

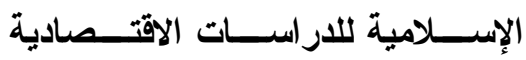
والإدارية - شــئون البحـــث العلمــي و الدر اسات العليا بالجامعة الإسلامية -

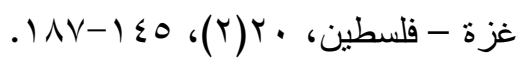

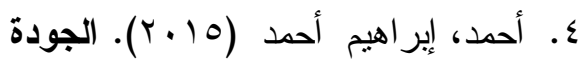

الـــشاملة فـــــي الإدارة التعليميــــة المدرسية، الاسكندرية، دار الوفاء.

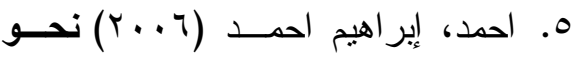

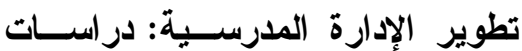
نظرية وميدانية الاســكندرية: مكتبــة

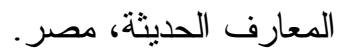

T. أحمــد، أحمـــد إبــر اهيم ( T T ( T ).

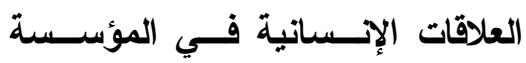
التعليمية، الإسكندرية، دار الوفاء. V. أحمد، أحمد إبر اهيم (Y.... المدرسية في مطلع القــرن الحسـادي والعشرين، طا، القاهرة: دار الفكـر

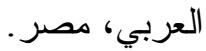
^. إدارة الجودة الثشاملة بـــوز ارة التعلــيم (Y.11)

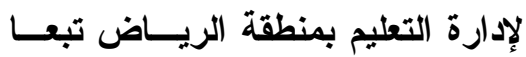

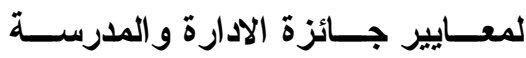
المتميزة. الريــاض: الإدارة العامـــة للتعليم بمنطقة الرياض.
- الاحتياجات التدريبيــة اللازمــة لقــادة

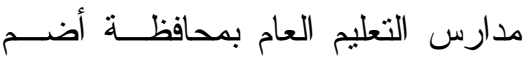
لتطبيــق معــايير الجــودة الــشاملة بمدارسهم.

- متطلبات تحقيق جودة البيئة المدرســية في مدارس التعليم العام بمحافظة أضم من وجهة نظر قادة المدارس ومعلميها. - منطلبات التحول الرقمي في مـــارس التعليم العام بمحافظة أضم من وجهـــة نظر قياداتها ومعلميها. - تطبيق موضوع و أداة الدراسة الحاليــة

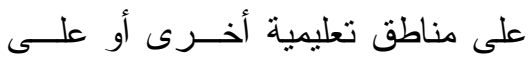

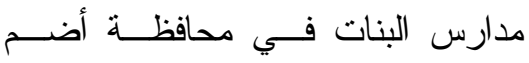

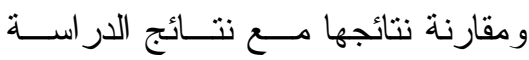

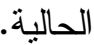

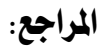

ا. ابن دهيش، خالد و الــشلاش، عبــــ الرحمن ورضوان، سامي (9 ( . ب). الإدارة و التخطيط التربوي : أسـس ورس

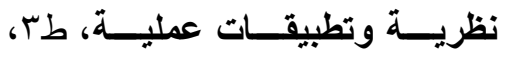
الرياض : مكتبة الرشد. Y. أبو دلو، نافذه (• • (Y).معا نحو بيئة مدرسية آمنة. رسالة المعلم، عمان:

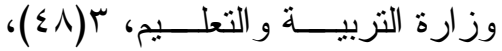
$.7 .-07$ r. أبوتايه، بندر • (r ا • r). أثر العدالـــة

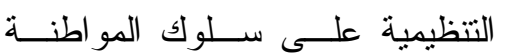


و المستهدفات للجهات المشاركة، وزارة

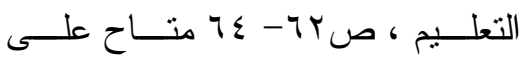

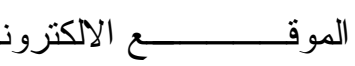

http://vision2030.gov.sa/sitesf

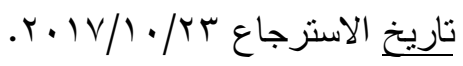
ـ ا ـبستان، أحمد و وحسن طـــه (9 . . ب).

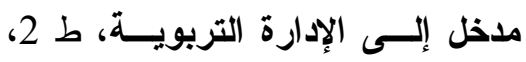
الكويت: دار القلم.

1 البطاينة، سناء محمد محمود (T 1 . Y).

دور مدير ات المدارس في تحقيق بيئــة مدرسية آننة في مدارس منطقة الباحة

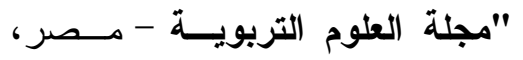

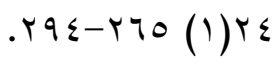
T ا.بني حمدان، خالد محمد(0 + r) إدارة

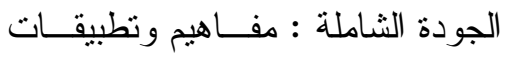

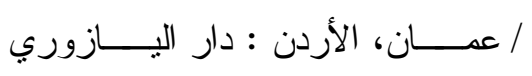
العلمية للنشر و التوزيع الاردن ندان

IV التزهوني، رمضان سعد كريم، بحيح،

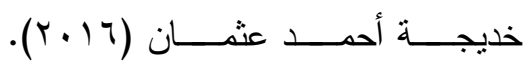

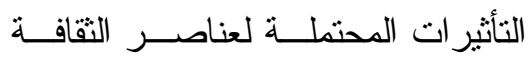

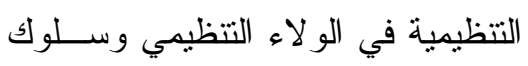

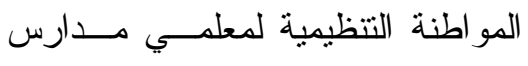
التعليم الأساسي بمدينة بنغازي. مجلــة

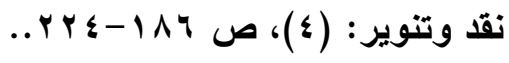

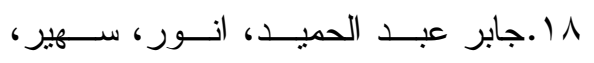

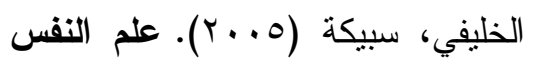
البيئي. القاهرة: دار النهضة العربية.

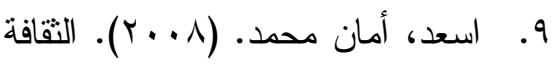

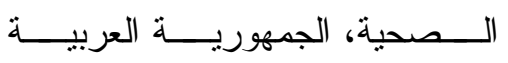
المصرية، القاهرة: دار الفجر للنشر.

• ا.الأغبري، عبدالصمد (0. . ب). إدارة

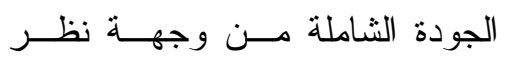
مديري ومعلمي المدارس الحكوميــة

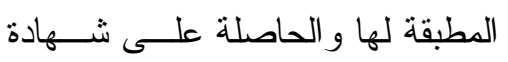

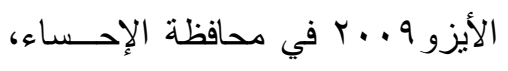

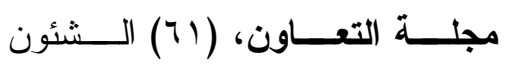

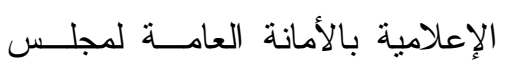
التعاون لدول الخليج، الرياض.

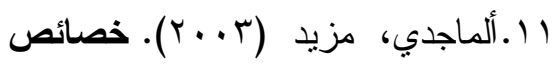
المدارس الابتدائية الفعالة من وجهة نظر مديري ومعلمي محافظة حفــر الباطن بالمملكة العربية الـسعودية، مدية مدية رسالة ماجسـتير غيــر منــشورة، باطيه الجامعة الأردنية، عمان، الأردن.

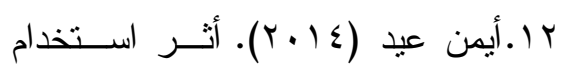
بعض استر اتيجيات ما ور اء المعرفة

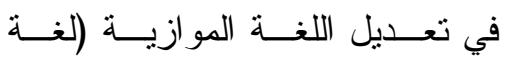
الروشنة) لدى طلاب المرحلة الثنانوية

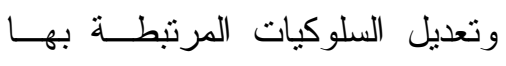
وتتمية الاتجاهات نحو اللغة العربية. در اسات نزبوية ونفسية، مجلة كليــة التربية بالزقازيق 11 11-9.9.r.

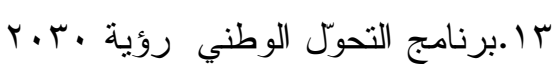

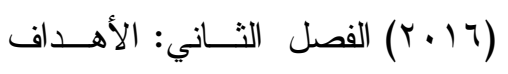




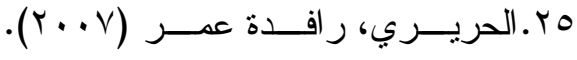

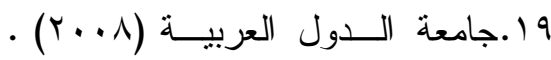

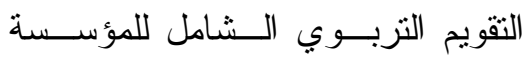

$$
\begin{aligned}
& \text { المدرســية - الأردن - عمـــان - دار } \\
& \text { الفكر التزبوي • }
\end{aligned}
$$

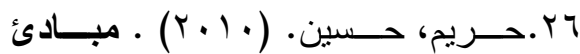

$$
\begin{aligned}
& \text { الإدارة الحديثة - لنظريات، العمليات }
\end{aligned}
$$

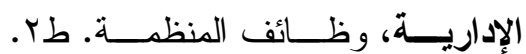

$$
\begin{aligned}
& \text { عمان: دار الحامد للنشر • }
\end{aligned}
$$

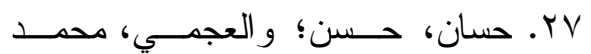

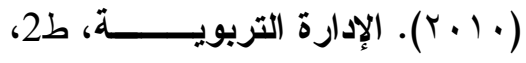

$$
\begin{aligned}
& \text { عمان: دار المسيرة للنشر و التوزيع. }
\end{aligned}
$$

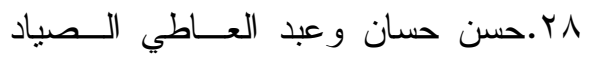

$$
\begin{aligned}
& \text { (Y...) }
\end{aligned}
$$

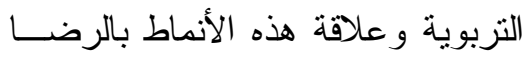

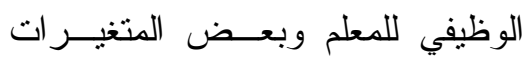

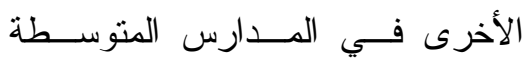

$$
\begin{aligned}
& \text { السعودية، مجلة رساية الخليج العربي، }
\end{aligned}
$$

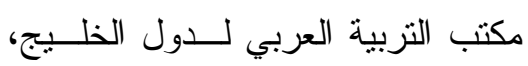

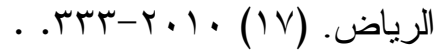

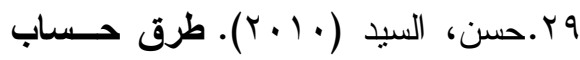

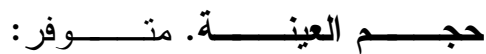

$$
\begin{aligned}
& \text { http://faculty.ksu.edu.sa/7081 }
\end{aligned}
$$

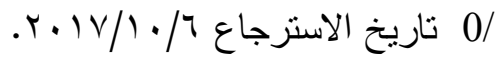

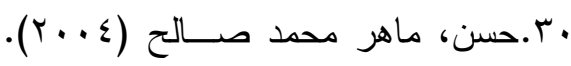

$$
\begin{aligned}
& \text { القيادة: أساسيات ونظريات ومفاهيم . } \\
& \text { طا، أربد: الاردن، دار الكندي للنشر ونطريات ومفاه } \\
& \text { المنظمة العربية للتربيــة و الثقافــة } \\
& \text { والعلوم إدارة التربية - خطة تطوير }
\end{aligned}
$$

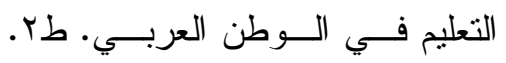

$$
\begin{aligned}
& \text { تونس. }
\end{aligned}
$$

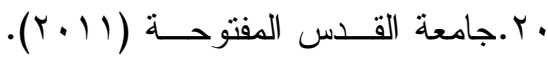

$$
\begin{aligned}
& \text { إدارة الصف وتتظيــه، منـشورات } \\
& \text { جامعة القــــس المفتوحــة، رام الله } \\
& \text { فلسطين. }
\end{aligned}
$$

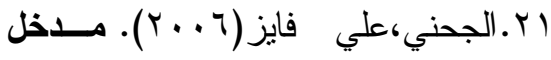

$$
\begin{aligned}
& \text { إلى العلاقات العامـــة والإِــسانية، }
\end{aligned}
$$

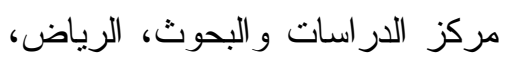

$$
\begin{aligned}
& \text { جامعة نايف العربية للعلوم الأمنية. }
\end{aligned}
$$

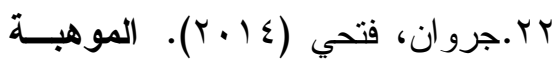

$$
\begin{aligned}
& \text { والتفوق والإبداع، عمان، دار الفكر . }
\end{aligned}
$$

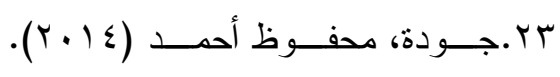

$$
\begin{aligned}
& \text { إدارة الجــودة الــشـاملة : مفــاهيم } \\
& \text { وتطبيقات. عمان: دار و ائل للنـشر } \\
& \text { و والتوزيع. } \\
& \text { و التوزيع. }
\end{aligned}
$$


V.r. الحناكي، طارق بـن محمـــ(10 (r). مقومات البيئة المدرسية الجاذبة للتعلم في المدارس الثانوية من وجهة نظر المعلمين و الطلاب" (رسالة ماجسستير

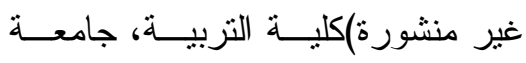
القصيم، بريدة.

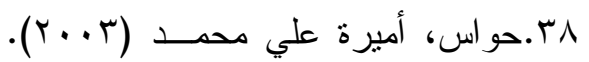
اثر الالتزام التنظيمي والثقة ي الادارة على العلاقة بين العدالـــة التنظيميــة

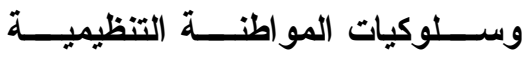
بالتطبيق على البنوك التجارية، رسالة ماجستير غير منشورة، كلية التجــارة، جامعة القاهرة-- مصر . 9. الخشروم، محمــد (Y99 (1)). المبــادئ و المهار ات و الوظــائف، الإســـكندرية: مركز الإسكندرية للكتاب. خطة التتمية

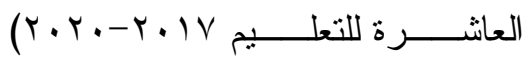
الأهداف العامة، وزارة التعليم في خطة

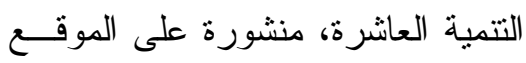
http://www.qassimedu.go edu/showthread.php?t=96174

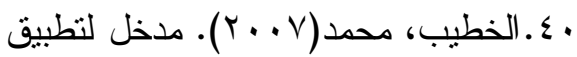

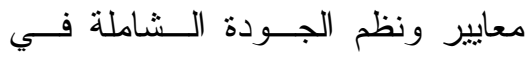
المؤسسات التعليمية، ورقة عمل مقدمة

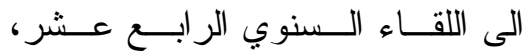

آ.حسن، ماهر محمد صالح. (T/ • (Y).

دور القيادة التحويليـــة لتطــــير أداء مديري ومديرات المدارس الاساسية في مدينة اربد. دراسات عربية فـي وميري

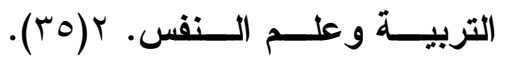
..) $\leqslant 0-|\pi|$

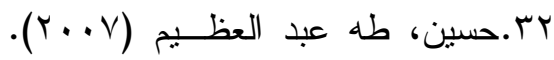

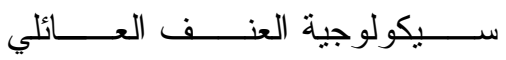
و المدرسي، مصر ، الإسكندرية: دار الجامعة الجديدة.

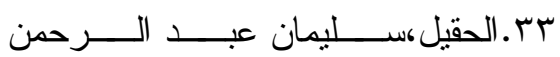

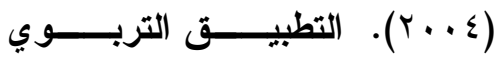
للعلاقات الإنــسانية فــي المجــال

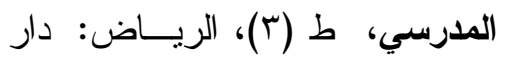

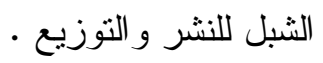

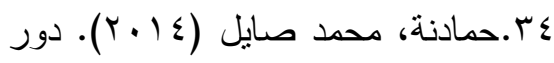
الإدارة المدرسية في الحد من ظاهرة العنف في المدارس الأردنية. المجلة التريوية الدولية المتخصصة، r(V) .VY-0T هب.الحمـــادي، عبــــ الله بــن محمــــ.

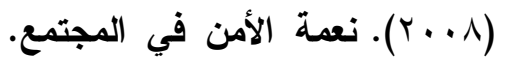

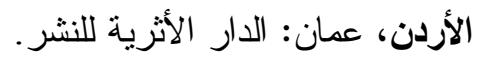

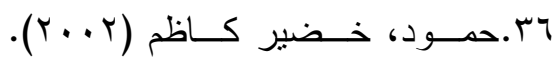
السلوك الإداري .عمان: دار الصفاء للنشر و التوزيع. 
و القيادة الإدارية، جدة، مكتبة الثقري.

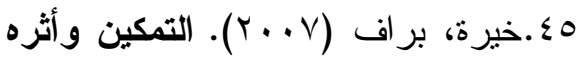

على المواكبــة التنظيميـة، رســالة

ماجستير غير منشورة، معهد العلــوم

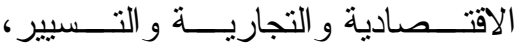

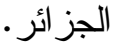

7ـ ـدرندري، إقبال زين العابدين وهــوك،

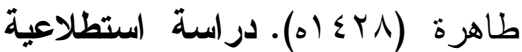

لآراء بعض المسئولين وأعضاء هيئة

التّريس عن إجراءات تطبيق عمليات

التقويم وتوكيد الجودة في الجامعـات

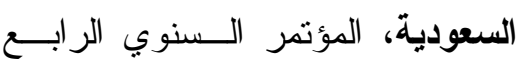

عشر للجمعية السعودية للعلوم النفسية

و التزبوية (جستن). المنعقد في الفتــرة 29-28 ربيع ثاني، القصيم.

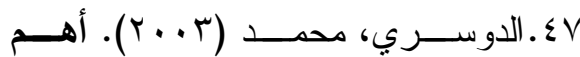

المــشكلات التـــي تواجـــه المبــاني

المدرســية الحكوميــة و المــــتأجرة

بالمرحلة الابتدائية للبنين (المـستقلة والمبه

وذات المراحل المشتركة) بمحــافظتي

وادي الدواسر والسليل من وجهة نظر

كل من مديري المـــارس الابتـائيــة

والمـشرفين التربــويين والإداريـينين

و المهندسين، رسالة ماجسـتير غيـر

منشوره، معهد البحوث العلمية، جامعة

أم القرى، مكـــة المكرمـــة، المملكـــة

العربية السعودية.
الجمعية السعودية للعلوم التربويـــة و النفسية (جستن)،الرياض.

اء.الخلايلة، هـدى أحمــد، (•. (ب).

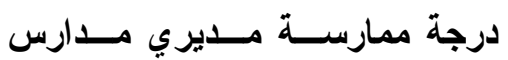

محافظة الزرقاء ومدير اتها للقيـادة

التحويلية وعلاقتها بسلوك المو اطنة

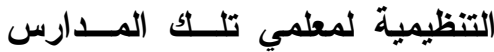

ومعلماتهــا، رسالة دكتـــور اه غيــر

منشورة، الجامعة الأردنية، عمـــان،

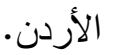

rع.خليفة، محمد عبد اللطيف (199v).

محددات سلوك التطوع التنظيمي في

المنظمات العامة، دراســة تحليليـــة

ميدانية في ضوء بعض النظريــات

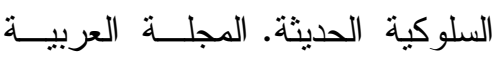

للعلوم الإدارية، •(1) مجلس النــشر

$$
\text { العلمي، جامعة الكويت. }
$$

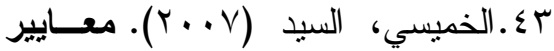

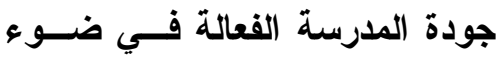

منحى النظم (رؤية منهجيــة)، اللقاء

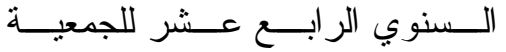

السعودية للعلوم التزبويــة و النفــسية

(جستن)، الفترة من 10-7 19 مــايو

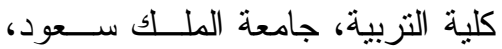

الرياض، المملكة العربية السعودية.

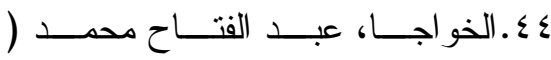

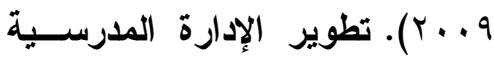


عمان: دار المسيرة للنـشر و التوزيــع و الطباعة.

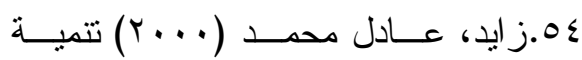

سلوك المو اطنة التنظيمي للعاملين فـي

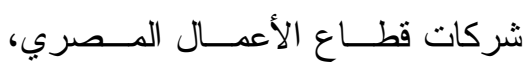
در اسة تطبيقيـة، مجلـــة المحاســبة

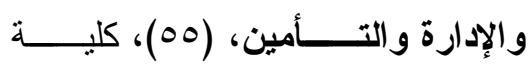
التجارة، جامعة القاهرة. 00. الزهر اني، محمد بن عبداله (Y... (Y). سلوك المواطنة التنظيمية لاي معلمي مدارس التعليم العام الحكومية للبنين بمدينة جدة من وجهة نظــر مــديري ومعلمي تلكك المدارس (رسالة ماجستير

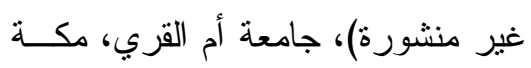
المكرمة.

07. الز هر انـــي، محمـــد علــي عطَّــاف.

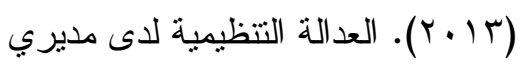

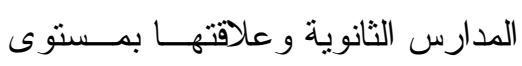

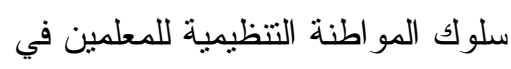
محافظة المخواة. (رسالة ماجستير غير

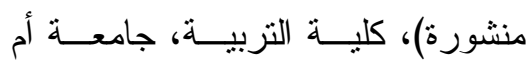
القرى: مكة المكرمة.

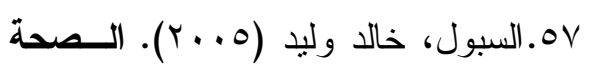

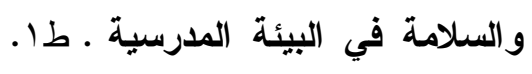

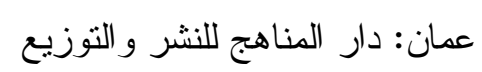

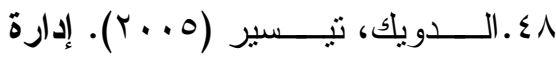

المدرسة الفعالة: مقوماتها و آفاقها. عمان: جهينة للنشر و التوزيع.

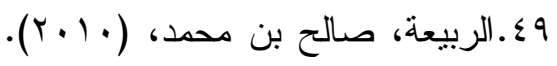
كفايات القيادة التحويليــة لمــديري مدارس التعليم العام، رسالة ماجستير

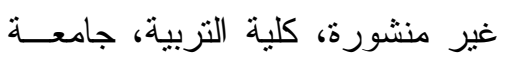
الملك سعود.

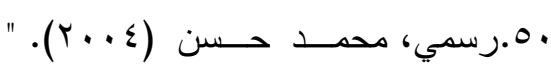
الــــوك التنظيمـــي فــــي الإدارة

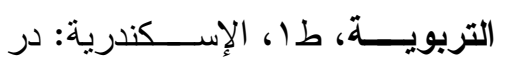
الوفاء للطباعة و النشر • النربه 01.رســمي، محمــــ (ع . . ب). الإدارة

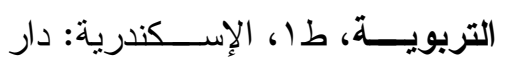
الوفاء للطباعة و النشر •

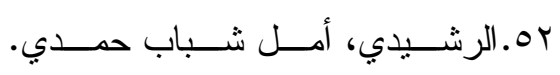

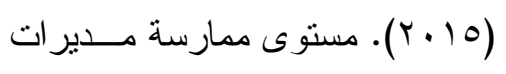

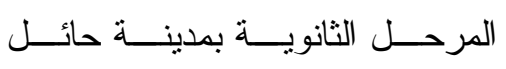

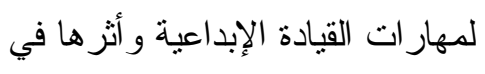

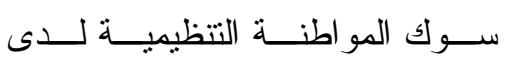
المعلمات. (رسالة ماجستير غيــر منشورة)، كلية التربيــة، جامعـــة أم القرى: مكة المكرمة.

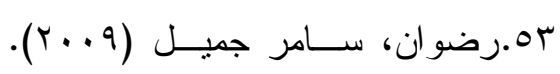

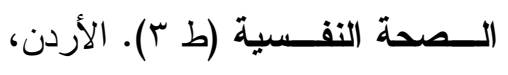


وجهة نظر هم. رسالة ماجسنير غيــر

منشورة. جامعة الثرق الأوسط. عمان

$$
\text { الأردن. }
$$

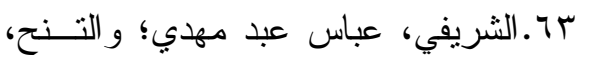

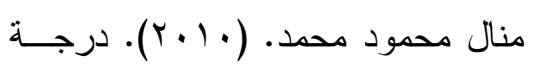

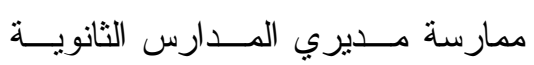

الخاصة في دولة الإمــار ات العربيــة

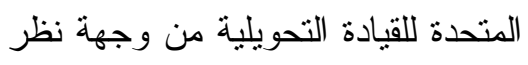

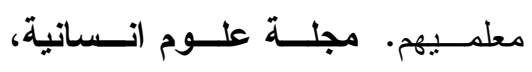

$$
. r-1,(\leqslant 0) V
$$

ـ 7.شعلة، الجميل محمــــ (999 (1) ). أثـــر

تفاعل الدافع المعرفي و البيئة المدرسية

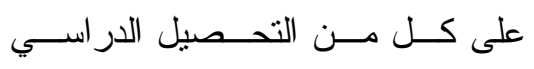

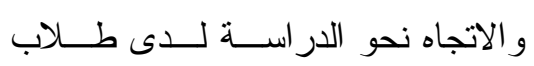

المدرسة الثانوية الصناعية. مجلة علم الاثية

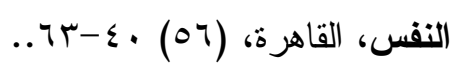

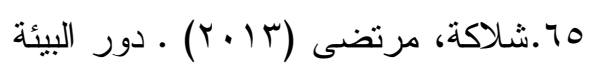

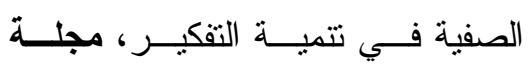

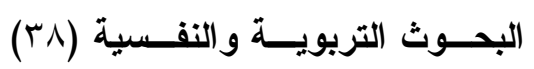

$$
\text { ror-rrq }
$$

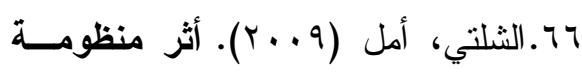

$$
\text { البيئة المدرسية فــي تنميــة القـيم }
$$

\section{الإبداعية التشكيلية لمادة التربية القنية}

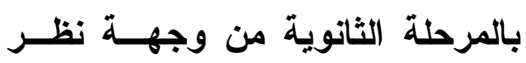

المعلمات، (رســالة ماجـستنير غيــر

منشورة)، جامعـــة أم القــرى، مكــــة ماجة

المكرمة، المملكة العربية السعودية.
01.01الـسلوم، ســعاد (0. . ب ). عوامـل

ضغوط العمل التنظيمية وعلاقتهــا سونا

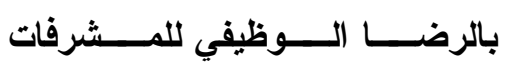

الإداريــات، رسالة ماجـستير غيــر

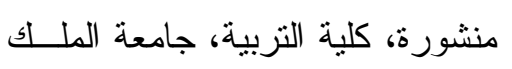

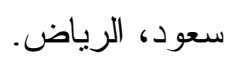

09.سليم، محمد (Y. . . . م). نمــط البيئــة

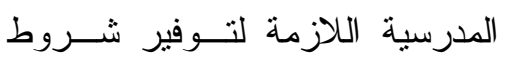

التربية الإبداعية، المجلة التربويــة،

جامعة جنوب الوادي، مصر (Y) (IV)،

$$
. r V V-r \leqslant r
$$

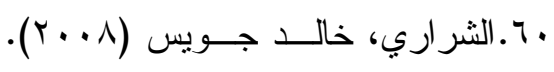

دور مديري المدارس في مواجهــة

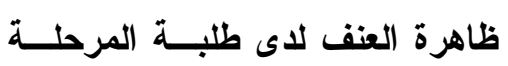

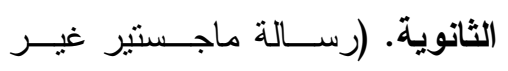

منشورة)، جامعة اليرموك، الأردن.

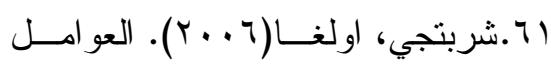

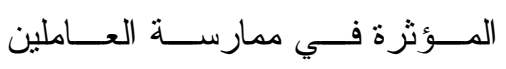

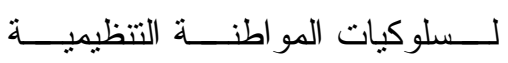

بالنطبيق على المشافي الجامعية فـي

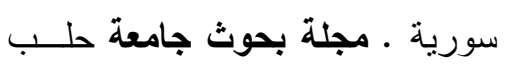

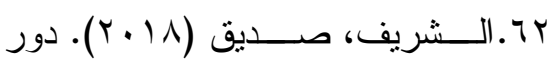

مديري المدارس الثانوية الخاصة في

محافظة العاصمة عمان فــي تتميــة

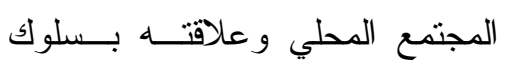

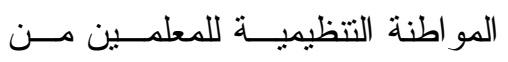


العاملين في القيادة علي العلاقة بـين العدالة التنظيمية وسلوكيات المواطنة التتظيمية". رســالة ماجسـتير غيــر

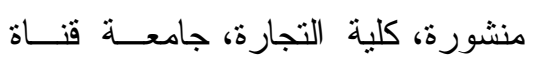

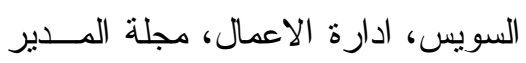
الناجح.

Vr.Vr

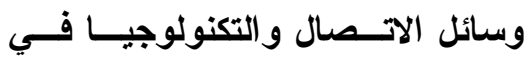
التعليم. الكويت: دار القلم.

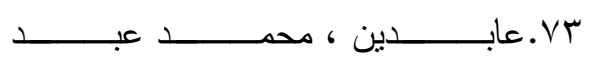

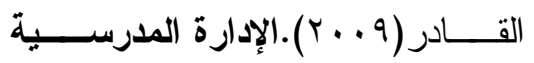
الحديثة، عمّان : دار الثروق للنـشر الإدة و التوزيع.

ع V.العارفة، عبداللطيف عبــــاله، قــــان،

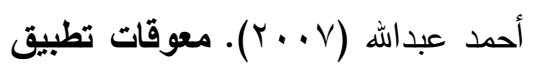
الجودة في التعليم العام من وجهة نظر

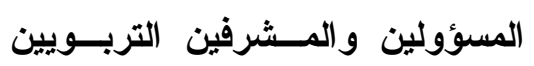
ومديري المدارس في منطقة الباحسة

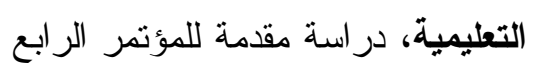

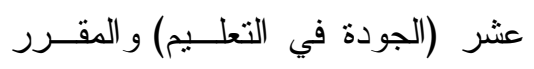
انعقاده في منطقة القصيم •

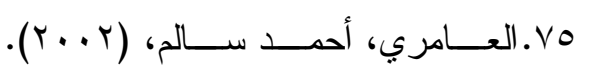

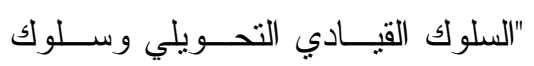

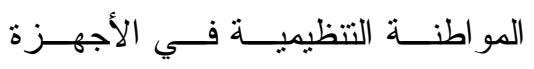

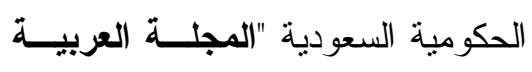

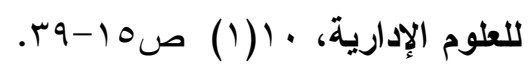

7V

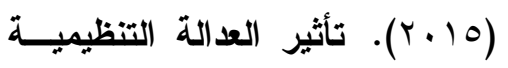
كمتغير وسيط علــى العلاقِـــة بــين تمكين العاملين والاستغراق الوظيفي بالتطبيق على العــاملين بمديريــة التربية والتعليم بمحافظة الدهلقبــة، رسالة ماجستير غير منشورة، كليــة

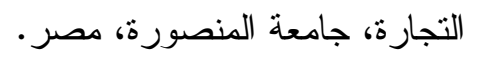

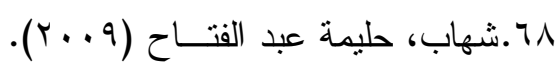
أثر المناخ التنظيمي علــى الرضـــا الوظيفي لــــى معلمـــي ومعلمـــات المدارس الثانوية، رسالة ماجـستير معلي ومعيسات غير منشورة، الجامعــة الأردنيــة، ماجية عمان.

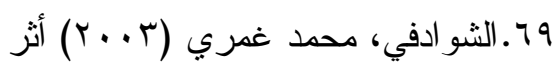
الدعم التتظيمي على سلوك المواطنة، در اسة تطبيقية على مديري البنـــوك

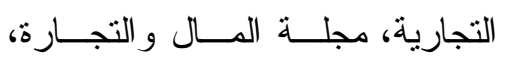
(Y)،كلية التجارة، جامعة الزقازيق.

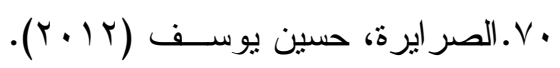

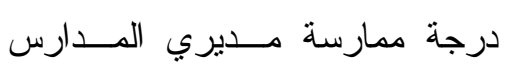
الثانوية: القيادة التحويلية وعلاقتهــــا

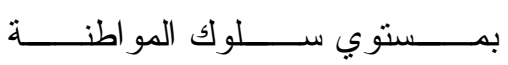

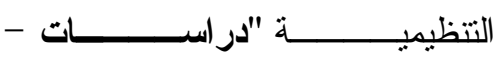

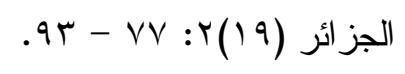

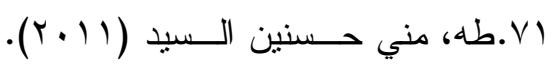

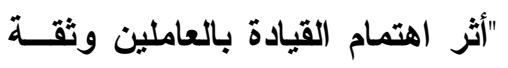




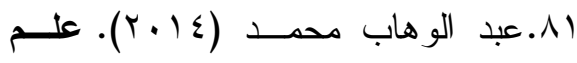

النفس البيئي، القاهرة: مكتبة الأنجلو

$$
\text { المصرية }
$$

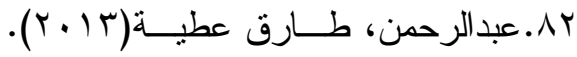

دليل تصميم وتنفيذ البحوث في العلوم

الاجتماعية: مــنهج تطبية ولــي لبنــاء

المهارات البحثية. الريــاض: الإدارة

العامة للطباعة و النشر بمعهـد الإدارة

العامة.

rم.عبيدات، ذوقان؛ وعبــــالحق، كايــد،

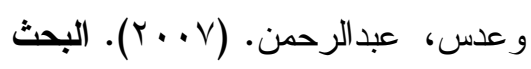

العلمي: مفهومه و أدواته وأســاليبه،

عمان: دار الفكر .

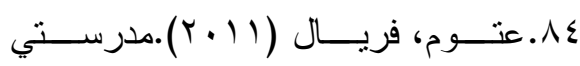

مسؤوليتي. رســالة المعلــم، عمــان:

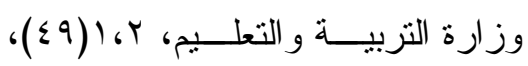

$$
\text { . }
$$

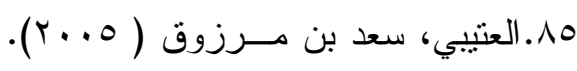

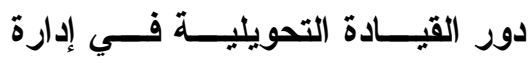

التغيير · ورقة عمل للملتقـى الإداري

الثالث إدارة التغيير ومنطلبات التطوير

في العمل الإداري جدة-المملكة العربية

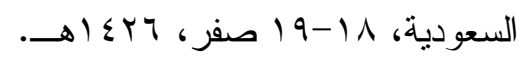

1^.العتيبي، محمد عبد المحسـن طبيــب

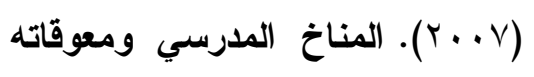

ودوره في أداء المعلمـين بمراحسل
V7. العامري، أحمد بــن ســالم(991 ())،

نحو نموذج متكامل للعوامل المؤثرة

و النتائج المترنبة على الدو افع الذاتية

للموظف، مجلة جامعة الملك سعود،

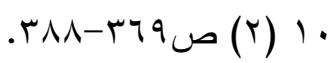

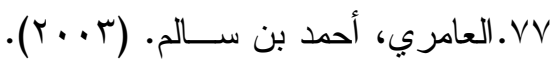

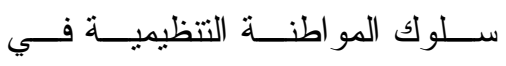

مستشفيات وز ارة الــصحة: در اســـة

استطلاعية لآر اء المــديرين. مجلــة

جامعة الملك عبدالعزيز، الاقتــصاد

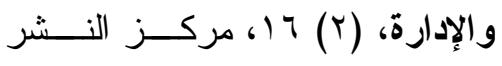

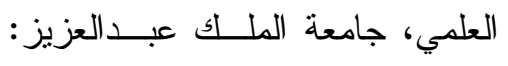

جدة.

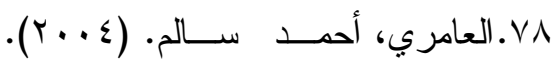

محددات و آتـــار ســلوك المواطنـــة

التنظيمية في المنظمات. مجلة جامعة

الملك عبدالعزيز، الاقتصاد و الإدارة،

جامعة (Y) (Y)

جامعة الملك عبدالعزيز : جدة.

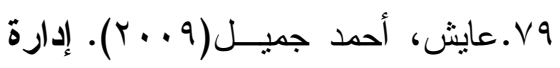

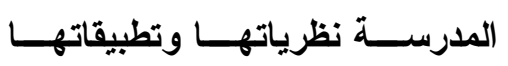

التريوية، عمان: دار المسيرة.

•..عبد المنعم، نادية محمد ومــصطفى،

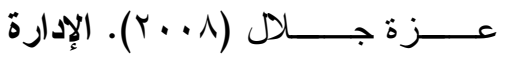

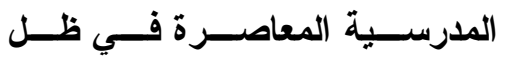

المتغيــــرات العالميــــة. القـــــاهرة

المجمو عة العربية للتدريب و النشر . 
منشورة ـ كلية النزبية، جامعة الأزهر : فلسطين.

19.9طوي، جودت عزت (• (1)).الإدارة المدرسية الحديثة (مفاهيمها النظرية

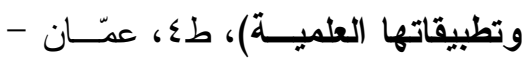
الأردن: دار الثقافة للنشر و التوزيع.

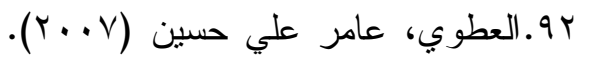

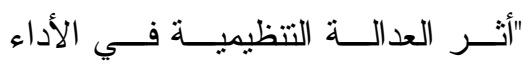
السياقي، در اسة تحليلية لآر اء أعــضهاء الكادر التدريسـي فـي كليــة الإدارة

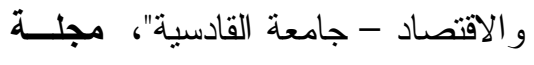
القادسية للعلوم الإدارية والاقتصادية، جامعــــة القادســــــة كليــــــة الإدارة و الاقتصاد، قسم إدارة الأعمال، • (1)

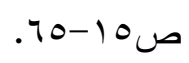

rq.عقيل حسين عقيل (· ( • (r). خطــوات

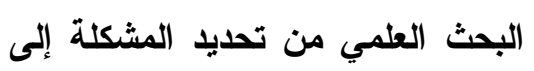
تفسير النتيجة. دمشق: دار ابن كثير .

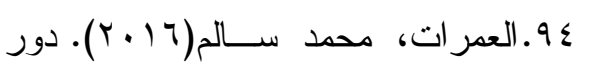
المعلم في توفير بيئة مدرسية آمنة في مدارس مديرية تربية الطفيلة ".مؤتـــة للبحوث و الار اسات - العلوم الآسانية

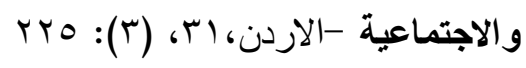

$$
\text { . ro. - }
$$

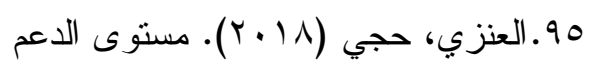
التنظيمي المدرك في المدارس الثانوية
التعليم العام - دراسة ميدانية على عينــة مــن المعلمــين العــاملين بالمدارس الحكومية بمدينة الرياض، رسالة ماجستير غبر منشورة، جامعة

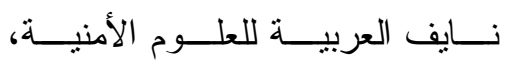

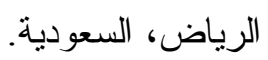

AV V.العجمي، معـدي ســود عبـدالله،

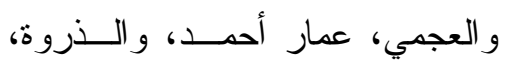

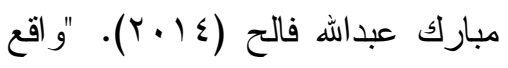
البيئة المدرسية بدولة الكويت و أثز ها

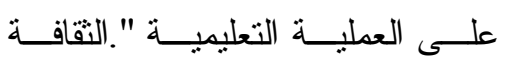

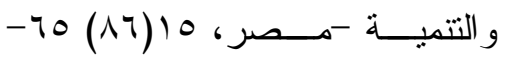
$.1 . \varepsilon$

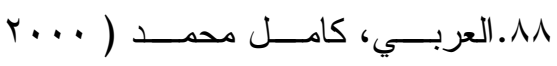
).العلاقات الإنسانية في المنظمــات الحكومية، دمشق: الدار المروانيـــة الإنسة للنشر و التوزيع.

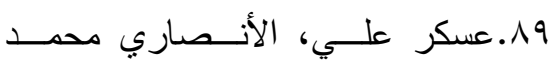

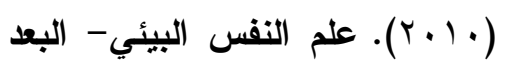
النفسي للعلاقة بين البيئة والسلوك. القاهرة: دار الكتاب الحديث.

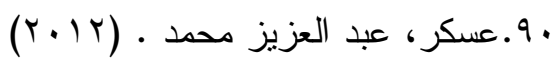
. القيادة التشاركية وعلاقتها بالثقافة

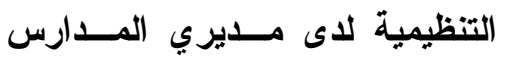
الحكومية بمحافظات غزة من وجهة نظر المعلمين • رسالة ماجسنير غير 
ماجسـتير غيــر منــشورة)، جامعــة السلطان قابوس، عمان.

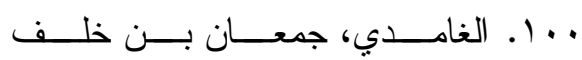

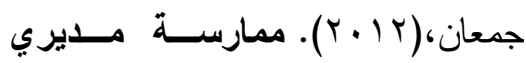
مدارس التعليم العام للقيادة التحويلية بمحافظة المخواة، رســالة ماجسستير

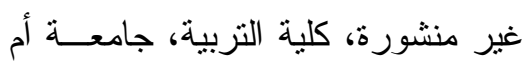

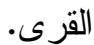

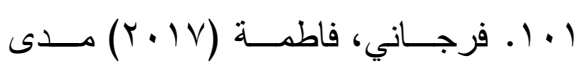
تو افر سلوكيات المواطنة التتظيمية لاى هره العاملين في المعهد العالي للمهن الطبية

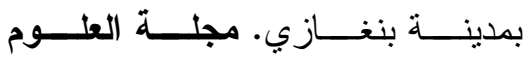
الاثتصادية والـسياسية. العـدد (9). $.15 \cdot-91$ Y. ا. فر غلي، حمد، محمد شعبان، و عبد

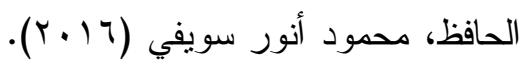
جودة بيئة التعلم وعلاقتها بالاتجاهــات نحــــو الـــتعلم و اكتـــشاف الطـــــلاب المو هوبين بالمرحلة الإعدادية بأسيوط:

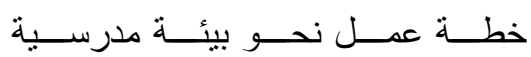

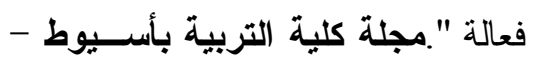
مصر، rr. r. المناخ الصفي بكل من التحصيل فـي التي

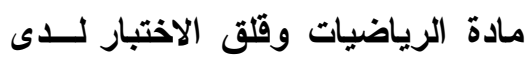
طلبة الصف الثاني الثانوي العلمي في
بمحافظة حفر الباطن وعلاقته بسلوك المواطنة التتظيمية لــدى المعلمـين

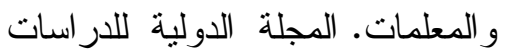

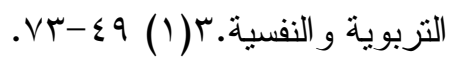

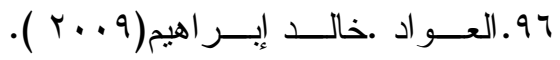
المدرسة الجاذبة، "تماذج لتجــارب التهاب

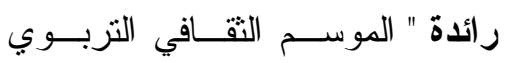

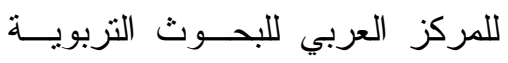
لدول الخليج ، الدورة السادسة عشر

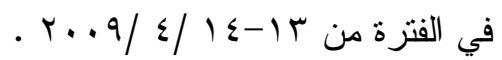

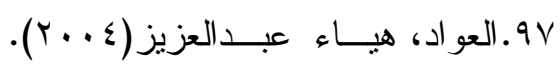

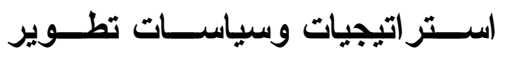
التعليم العام في المملكـــة العربيــة السعودية، رؤية مستقبلية، (رســالة

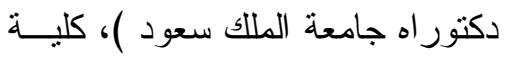
التربيـــة ، قــسم الإدارة التربويــــة،

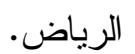
91.عويسات، مجـدي (T . . r). الإدارة

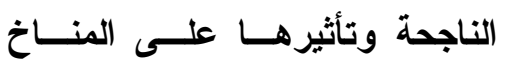

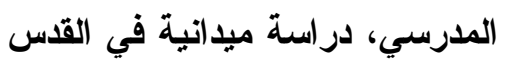

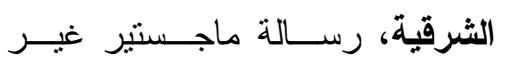
منشورة، كلية التربية، جامعة النجاح الوطنية، نابلس.

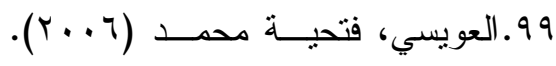
واقع إدارة السلامة المدرسية فــي مدارس التعليم العام للصفوف مسن

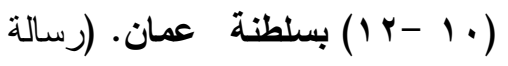




\begin{tabular}{|c|c|}
\hline 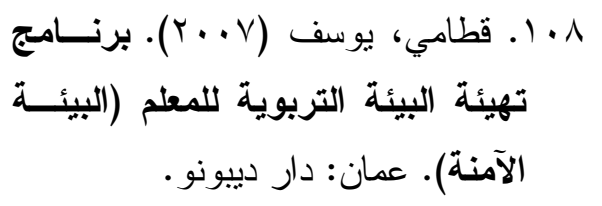 & مدارس الجنوب.رسالة ماجستير غير \\
\hline 9 ـ ا ـ قمر الدين، عثمان و الكنين، فاطمـ & ـ ـ ا. فلية ، فاروق عبده، وعبدالمجيــــ \\
\hline 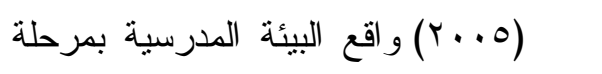 & الــسيد محمـــد (ع ا • ب). الــسلوك \\
\hline 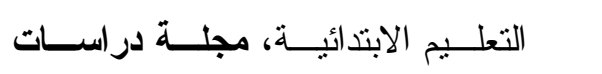 & التنظيمــي فــي إدارة المؤســسـات \\
\hline تربوية، آr، 9r-00.. & التعليمية، عمان: دار المسيرة. \\
\hline •11. القوزي، بلغيــث أحــــ (1991) & هـ 1 ـ فؤ اد أبو حطب و أمسال صــادق \\
\hline 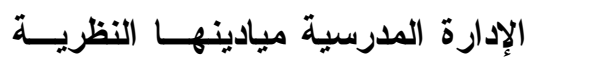 & 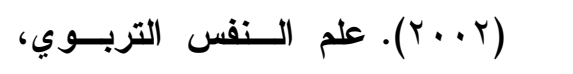 \\
\hline و العلمية، الرياض: مطابع الفرزدق. & طل، القــــاهرة: مكتبـــــة الأنجلـــــو \\
\hline 111.. الكايــد، جعفــــ (1999) الــــلاء & 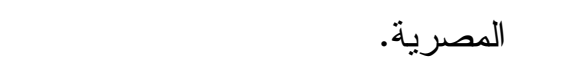 \\
\hline التنظيمي فـــي الجامعــات الرســــ & 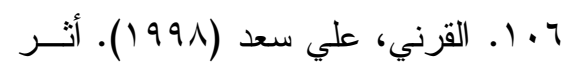 \\
\hline الأردنية :در اسة ميدانية من وجهة نظر & الــــمط القيـــادي علـــى أســـلـوبي \\
\hline أعضاء هيأـــة التــــريس". رســالة & عمل وتعامل المعلمين مع الطــلاب \\
\hline ماجستير غير منشورة جامعة الليرموكك & داخل الفصل الدراسي فــي المـــداس \\
\hline 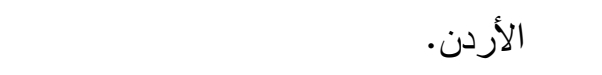 & الثانوية للبنــين بالريــاض، مجلـــة \\
\hline 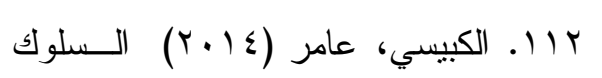 & در اسـات تربويـــة، ر ربطـــة التزبيـــة \\
\hline التتظيمي، الدوحة: مطابع دار الثرق. & 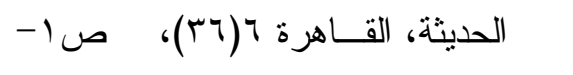 \\
\hline 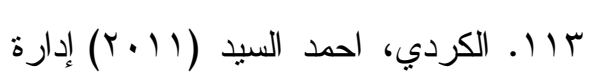 &.$\leqslant 7$ \\
\hline السلوك التتظيمي، كتــاب الكترونـــي & 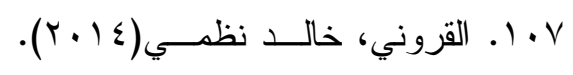 \\
\hline 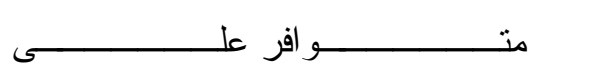 & دور الادارة المدرســية فــي ايجــاد \\
\hline https://faculty.psau.edu.sa/.../d & بيئة مدرسية مشوقة فــي مـــارس \\
\hline تـ oc-5-doc- & فلسطين - محافظة سلفيت انموذجاً. \\
\hline 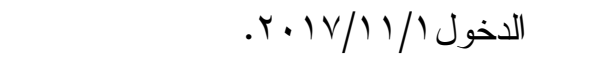 & مجلة جامعــة القـــس المفتوحــة \\
\hline ـ 1 ا. الكريمين، هاني أحمــــ؛ العــــر ات، & للأبحـــــاث و الدر اســـــات التربويــــة \\
\hline محمد سالم؛ الحجايا، ســليمان ســـالم، & والنفسية - فلـسطين، Y، (0): 10 \\
\hline • مـــدى ممارســــة مــدير : & $99-$ \\
\hline
\end{tabular}




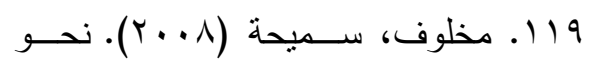

مدرسة مصرية فعالة "تصور مقترح"، مدلة

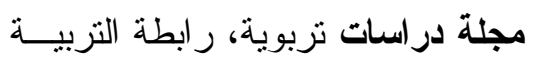

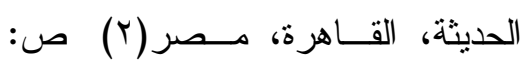

III-r .

• ץ . مساد، عمر حسن(0. . . ץ). الإدارة

$$
\text { المدرسية، عمان، دار صفاء. }
$$

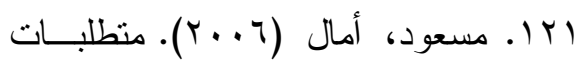

تهيئة البيئة المدرسية لتخفيف مهارات

التعلم الذاتي و المستمر لدى تلاميذ حلقة

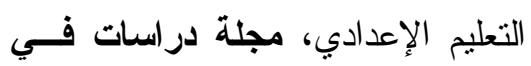

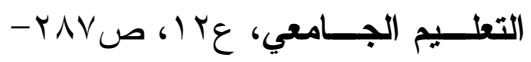

זד.

r I ا . مــصطفى ، صـــلاح عبدالحميــد

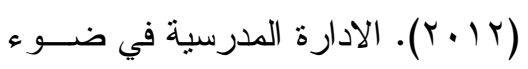

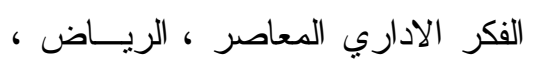

دار المريخ.

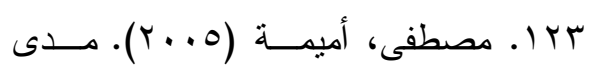

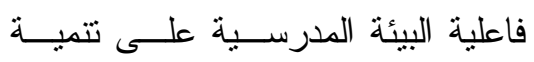

الابتكار ومفهوم الذات، مجلة دراسات

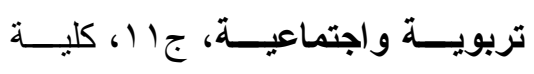

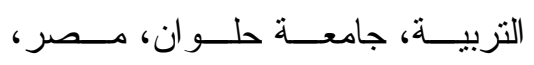

$$
\text { صس }
$$

ع ا. المطيري، محمــــ راثــد غــازي

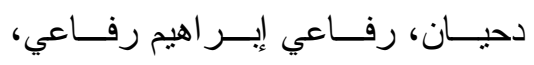

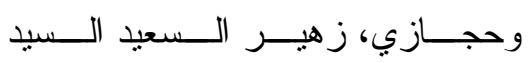

المدارس ومـــدير اتها فـــي محافظـــة

الطفيلة لسلوك القيادة التحويلية مسنـ

وجهة نظر المعلمين، مجلة العلــوم

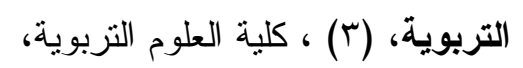

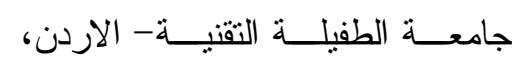

ج 9

110

الإدارية. عمان، الأردن: دار الثقافة

$$
\text { للنشر و التوزيع. }
$$

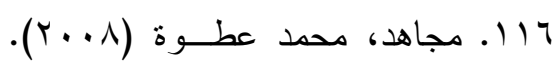

المدرسة و المجتمع في ضوء مفاهيم

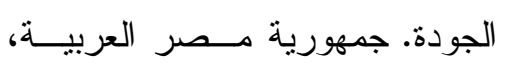

الإسكندرية: دار الجامعة الجديدة.

IV V

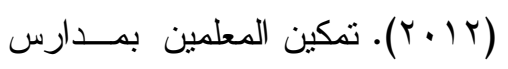

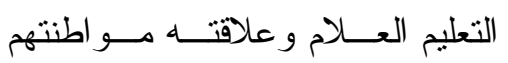

التتظيمية. دراسات عربية في التربية

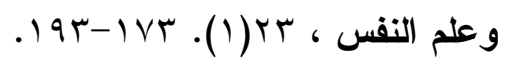

111. محمد، ســامية الـسيد محمــود،

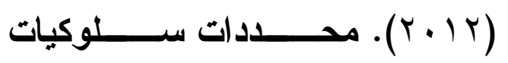

المواطنة التنظيمية: دراسة تطبيقية

على الوحدات الحكومية بمحافظــة

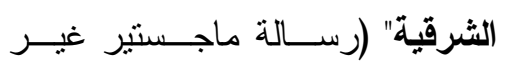

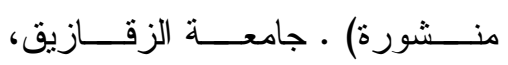

الزقازيق. 
الرياض، جامعة الملك سعود ، مجلـــة كلية العلوم الإدارية (r T ())، الرياض. •T ا. المؤمني، محمد احمد (T . . ץ): أثز نمط التتشئة الأسرية في الأمن النفسي لدى الأحداث الجــانحين فـــي الأردن.

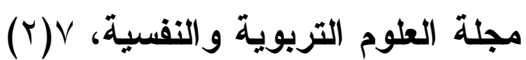

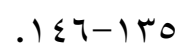

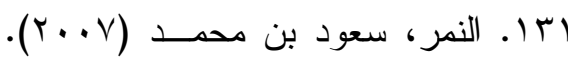

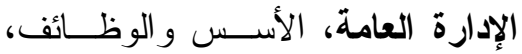

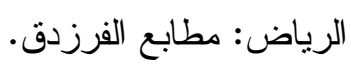
بسا ـ نوح، هوازن محمــــ عبــدالوهاب. (T)

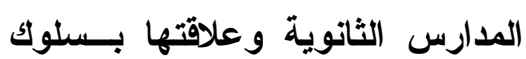

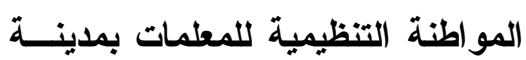
مكة المكرمة. (رسالة دكتور اه غيـر

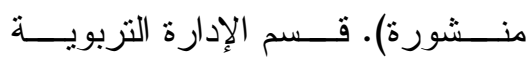

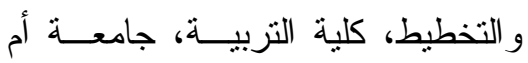
القرى: مكة المكرمة.

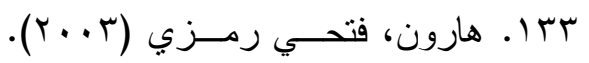
الإدارة الصفية. عمان: دار و ائل للنشر

$$
\text { و التوزيع. }
$$

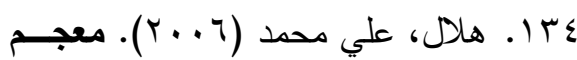
المصطلحات الإدارية، مركز الدراسات

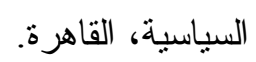

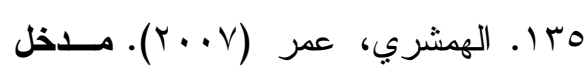$$
\text { الى التربية. (ط )،عمان: دار صفاء. }
$$

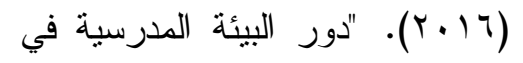

رفع مستوى الرضا الوظيفي لمعلمي

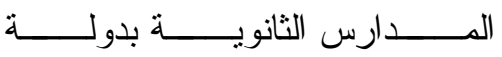

الكويت ".مجلة القراعة والمعرفة -

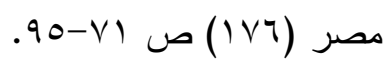

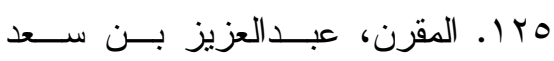

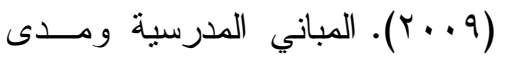

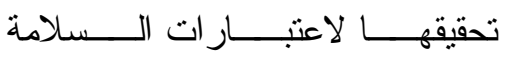

الثخصية، الرياض، النشر العلمـي لـاني مطابع جامعة الملك سعود. דr 1. ملحم، سـامي محمـد (10 (Y).

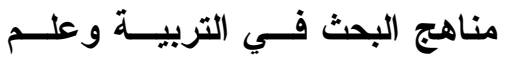
النفس. طV. عمّان: دار المسيرة.

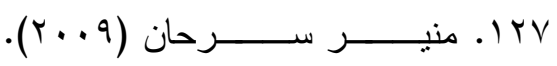
اجتماعيات التربيــة، بيــروت: دار النهضة العربية. 1Y1. المهدي، ياسر فتحــي الهنـــاوي.

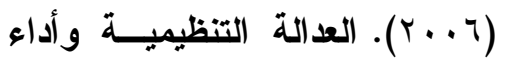
المعلمين لسلوك المواطنة التنظيمية بالمدارس الثاتوية العامة في مصر. (رسالة دكتور اه غير منشورة) كليــة

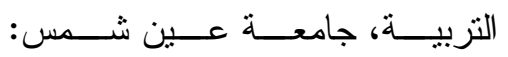
جمهورية مصر العربية.

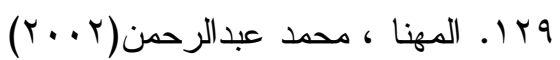
العو امل المؤثرة على فعالية تطبيـق إدارة الجودة في إدارة التعليم بمنطقة 
141. Altinkurt, Y., \& Yilmaz, K. (2012).

"Relationship

between

school

administrators'

organizational

sources and

Educational

power

eachers".

Sciences:

Theory and Practice, 12(3)

1843-1852. Retrieved from www.edam.com.tr/estp.

$1 / 10 / 2016$

142. Asiyai, R. (2014). Students' Perception of the Condition of their Classroom Physical Learning Environment and its Impact on their Learning and Motivation. College Student Journal, 48,716-726.

143. Aydin

B. (2012)

Transformational Leadership

Behaviors of School

Principals: A Qualitative Research Based on Teachers' Perceptions International Online Journal of Educational Sciences, 4 (3), 581-591

144. Babcock-Roberson, M. E. \& Strickland, O. J. (2010). The Relationship Between Charismatic Leadership, Work Engagement, and Organizational Citizenship Behaviors, The Journal of Psychology, 144 (3), 313326.

145. Babi, P.. (2014). Principal as Transformational Leader: Getting to Know New بrا. الهيئة القومية لضمان جودة التعليم

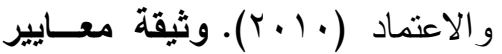

ضمان الجودة والاعتماد لمؤسسات

التعليم قبل الجامعي، الهيئة القوميـــة

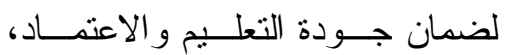

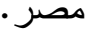

V IT الهيئة الوطنية للتقويم و الاعتمـاد

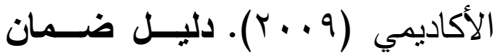

الجودة و الاعتمــاد الأكسـاديمي فــي

المملكة العربية السعودية. الرياض.

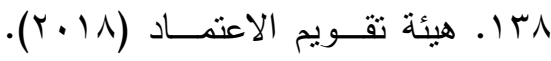

النسخة المطورة لمعايير الاعتمــاد

المؤسسي. الرياض: المركز الوطني للتقويم و الاعتماد الأكاديمي.

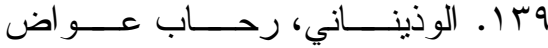

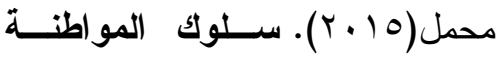

التنظيمية وعلاقتها بالو لاء التنظيمي

لاى مديرات مدارس التعليم العام في

مدينـــة مكــة المكرمــة، (رســـالة

ماجستير غير منشورة)، كلية التزبية، جامعة أم القرى.

140. Ahmet,AVCI .(2016). Effect of Leadership Styles of school principals on organization Citizenship Behaviors, Educational Research and Reviews,(11)11,pp10081024. 


\begin{tabular}{|c|c|}
\hline $\begin{array}{l}\text { citizenship Behaviors. } \\
\text { Personnel psychology. 48, } \\
\text { 775-802. } \\
\text { 150. Bostanci, A. (2013). "The } \\
\text { prediction level of teachers' } \\
\text { organizational citizenship } \\
\text { behaviors on the successful } \\
\text { practice of shared leadership". } \\
\text { Journal of Educational } \\
\text { Research, (51) 177-194. } \\
\text { Bullock, C. (2007) The } \\
\text { Relationship Between School } \\
\text { Building Conditions and } \\
\text { Student Achievement at the } \\
\text { Middle School Level in the } \\
\text { Commonwealth of Virginia, } \\
\text { Dissertation, faculty of the } \\
\text { Virginia Polytechnic Institute. } \\
\text { 151. Byamugisha. A, (2011). } \\
\text { "Examining the effects of } \\
\text { school environmental } \\
\text { factors on pupils's learning } \\
\text { achievement in Ugandan } \\
\text { primary schools". Paper } \\
\text { presented at the annual } \\
\text { meeting of the 55th Annual } \\
\text { Conference of the } \\
\text { Comparative } \\
\text { International Earmo } \\
\text { Society. Fairmont Le Reine } \\
\text { Elizabeth. Montreal. Quebec. } \\
\text { Canada. Apr } 30 . \quad \text { and } \\
\text { 152. Cara, Moor M. (2012). The } \\
\text { Role of School Environment } \\
\text { in Teacher Dissatisfaction } \\
\text { Among U. S. Public school } \\
\text { Teachers, University of }\end{array}$ & 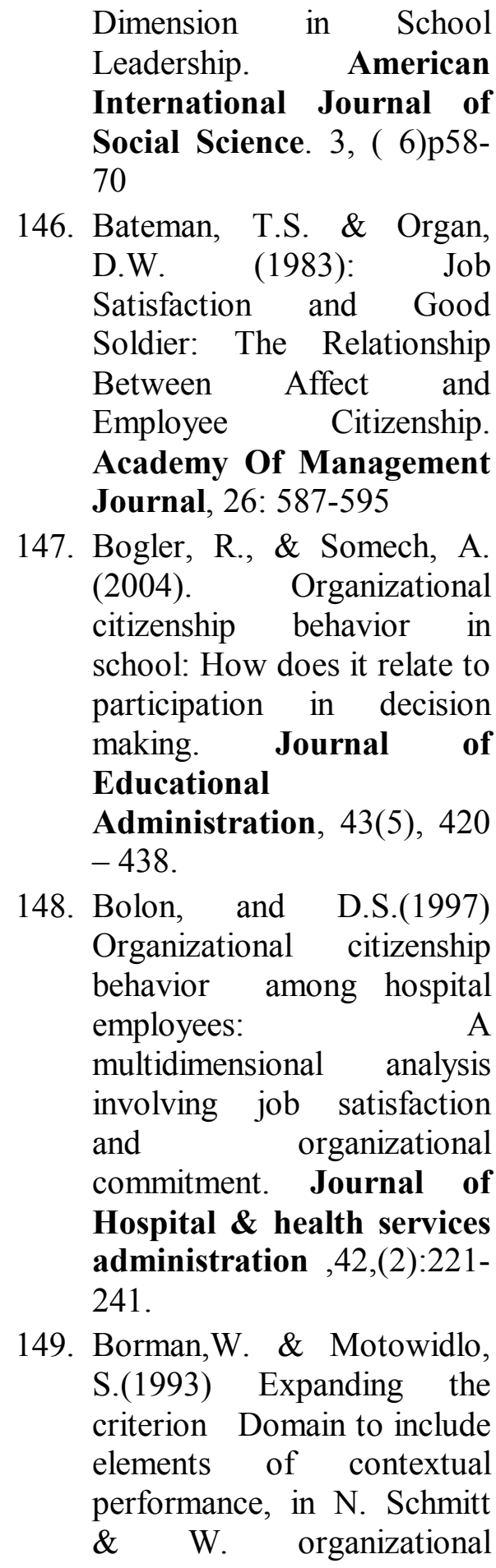 \\
\hline
\end{tabular}


organizational citizenship

behavior and schools effectiveness in Al bama public high schools . DAI A11/7. Proquest. UMI Dissertations.

Council For Exceptional Children. (2008). CEC'S Policy onSafe and Positive School Climate. Teaching

Children. 2. PP:41-42.

158. David, B. \& Berie. M.(2009) Job Satisfaction among Teachers effects of the Work Places. American Institute for Research, Washington D.C.

159. DiPaola Michael F. , Paula Maria Mendes da Costa Neves, (2009),"Organizational citizenship behaviors in American and Portuguese public schools", Journal of Educational

Administration, (4) $47 \mathrm{pp}$. 490- 507 .

160. Ellen,

$$
\text { D. (2000): }
$$

Adolescents' perceptions of safety at school and their solution For enhancing safety and reducing school violence: A rural case study,

161. Erdogan. Z., Kieser. K. J., Kim. S. H., Komm, B., Katzenellenbogen. J. A., \& Katzenellenbogen.

B. S. (2008). Nuclear and
Tennessee, Knoxville, USA, Sage Oren Journals, 24. 2.

153. Chen, C. \& Chung, R. (2007). The Effects of Leadership Styles of Principals in Senior Vocational High Schools for Teacher Organizational Citizenship Behavior and School Organizational Performance.

Contemporary

Educational Research

Quarterly, 15(3), 69-114.

154. Chen, C.C.\&Chiu, S.F. (2008). An Integrative Model Linking Supervisor Support and Organizational Citizenship Behavior, Journal of Business psychology, Vol. (23), PP.110.

155. Chiu, S., \& Tsai, W. (2007). The linkage between profit sharing and organizational citizenship behavior. International Journal of Human Resource Management, 18, 10981115.

156. Chyung, S. (2007). Invisible Motivation of Online Adult Learners During Contract Learning, The Journal of Educators Online, 4. (1) p1-29

157. Cooper, J. (2010). Collective efficacy, 
and Language Science, University of Newcastle.

167. Hoy, W. \& Miskel, C. (2005):

Education Administration:

Theory, research \& practice, New York: McGraw. Hill, USA.

168. Huangs $\mathrm{S}$; \& Waxmans $\mathrm{H}$, (2009). The Association of School Environment to Student Teachers Satisfaction and Teaching Commitments Teaching and Teacher Educations An International Journal of Research and Studies, 25s (2) PP:235-243.

169. Ischingers B.s \& Puukkas J. (2009). Universities for Cities and Regions: Lessons from the OECD Reviews. Change: The Magazine of Higher Learnings 41(3), 8-13.

170. Jones, S.; Alxelrad, R. \& Wattigneey, W. (2007): Healthy and safe school environment, Part 2, physical school environment: results from the school health policies and programs study, (2006): Journal of school health, 77 (8), 544-556

171. Katz, D.,\& Kahn, R.L.(2007). The Social psychology of organizations. (second Edition)New York.

172. Killian, J.; Fish, M.; Maniago, E. (2006): Making school safe: Asystem-Wide School extranuclear pathway inputs in the regulation of global gene expression by estrogen receptors.

Molecular endocrinology. 22 (9). 2116-2127.

162. Forrester, A \& Reinhare,, M. (2000).The learners way. Winnipeg, Manitoba, Peguis Publisher.

163. George, J. M. \& Bettenhausen, K. (1990): Understanding prosocial behavior, sales performance, and turnover: A group-level analysis in service context. Journal of applied psychology, 75, 798-809.

164. Göksoy ,Süleyman (2014) Participation of Teachers in School Administration and Their Organizational Citizenship Behaviors, International Journal of Humanities and Social Science (7) 4, p171-182

165. Gough, D. (2008). School Climate: Urban Parent's View, Educational Leadership, Sep,89-90

166. Higgins, S. (2005). The impact of School Environments; A literature review, The Centre for Learning and Teaching School of Education, Communication 
the Palestinian territories: an empirical study OECD. ISSNs PP:2072-7925.

178. Mcgowen, R. (2007). The Impact of School Facilities on Student Achievement, Attendance, Behavior, Completion Rate and Teacher Turnover Rate at Selected Texas, Dissertation University of Houston.

179. Nair, P. (2004). Planning Technology friendly School Buildings, An article available through: designshare. com/ Research $\backslash$ Nair.

180. Organ, D. \& Ryan, K. (1995). A meta- analytical review of attitudinal and dispositional predictors of organizational citizenship behavior ,Personnel psychology, 48:775-802.

181. Organ, D. W., Podsakoff, P. M., \& MacKenzie, S. B. (2006). Organizational Citizenship Behavior: Its Nature, Antecedents, And Consequences. London:

Sage.

http://onlinelibrary.wiley.com /doi/10.1111/j.17446570.2006.00043_9.x/full Retervaled1/10/2016

182. Organ D.W (1990). Organizational citizenship behavior: The good soldier intervention to increase student prosaically behaviors and enhance School climate. Journal of School applied Psychology, 23(1), 1-31

173. Konovsky, Mary A and Pugh, S.D.(1996)

Citizenship Behaviour and social Exchange, Academy of Management Journa,37(6):656-669.

174. Kose, E. (2009): Assessment of the Effectiveness of the Educational Environment Supported by Computer Aided Presentations at Primary School Level, Computers \& Educe on, 53

(4) $p$ 30-55

175. Lee, Y., Patterson, P., \& Vega, L. (2011).Perils to Self-Efficacy Perceptions and Teacher- reparation Quality among Special Education Intern Teachers. Teacher Education Quarterly, 1(1).1-33

176. Mackenzie, S, Podsakoff,P, Fetter, R,(1993) The impact of organization citizenship behavior on evaluations of salesperson performance, Journal of marketing , 57,1:70-80.

177. Matars Ms (2010). The impact of school design on academic achievement in 
Strategies in a Foreign Language Setting: A Look at a Learner of Koreans Carla Working Paper 14.

188. Rudd P; Reeds F; \& Smiths $\mathrm{P},(2008)$. The effects of the school environment young people's attitudes towards education and learnings National Foundation for Educational Research.

189. Sapon-shevin M. (1999). Because We Can Change The World: A Practical Guide To Building Cooperative, Inclusive Classroom Communities. Boston: Allyn \& Bacon.

190. Smith, C Ann, Organ ,Dennis W. and Near, Janet P. (1983). Organizational citizenship behavior its nature and antecedents, Journal of Applied psychology, 68 (4) :653-663.

191. Suleman, Q. Aslam, H \& Hussain, I.(2014). Effects of Classroom Physical Environment on the Academic Achievement Scores of Secondary School Students in Kohat Division, Pakistan, International Journal of Learning \& Development, 4(1) 71-81-

192. Swaleha, A.(2013). Creating safe school environment: Role syndrome. Lexington, mass., Lexington Books.

183. Podsakoff, P. Ahearne, M. and Mackenzie, S. (1997). Organizational citizenship behavior and the Quantity and Quality of work group performance, Journal of applied psychology,82:262270.

184. Polat, İ (2009). Organizational citizenship behavior (OCB) display levels of the teachers at secondary schools according to the perceptions of the school administrators.

Procedia Social and Behavioral Sciences 1 1591-1596

185. Putka, D. J (1999). The moderating effects of employee perceptions of behavioral discretion on the relationship between OCB and job satisfaction. Paper presented at the annual meeting of the Academy of Management, Chicago, IL.

186. Robbins, S.P. (2000). Organizational behavior: Concepts, controversies, and applications, Upper Saddle River, New Jersey: Prentice Hall

187. Root Elizabeth (1999). Motivation and Learning 


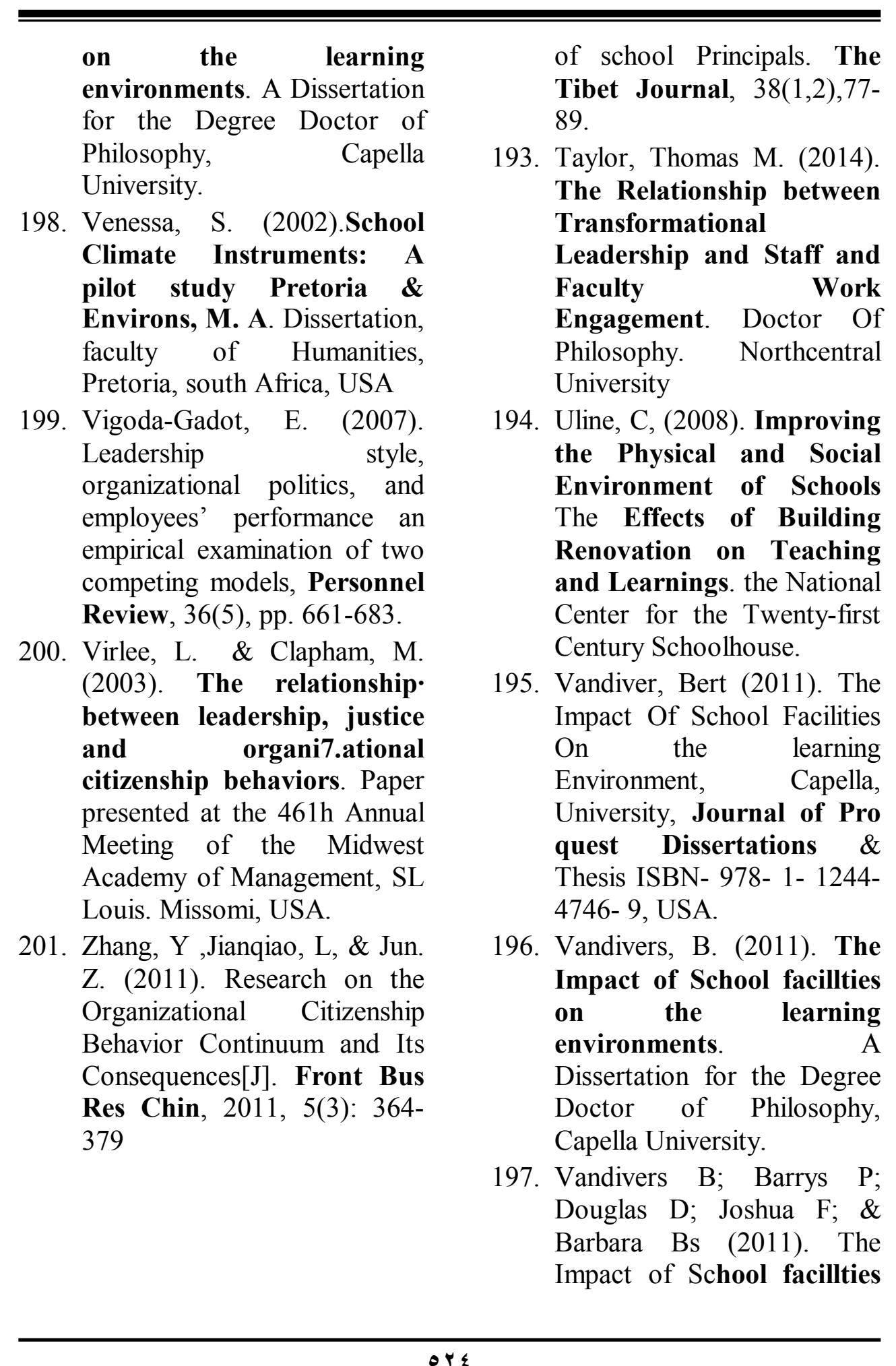

